Computational Approaches to the Study of Movement in Archaeology 


\section{Topoi Berlin Studies of the Ancient World}

Edited by

Excellence Cluster Topoi

Volume 23

De Gruyter 


\section{Computational Approaches to the Study of Movement in Archaeology}

Theory, Practice and Interpretation of Factors and Effects of Long Term Landscape Formation and Transformation

Herausgegeben von

Silvia Polla Philip Verhagen 
ISBN 978-3-II-02883I-5

e-ISBN 978-3-II-028838-4

ISSN 2I9I-5806

Library of Congress Cataloging-in-Publication Data

A CIP catalog record for this book has been applied for at the Library of Congress.

Bibliographic information published by the Deutsche Nationalbibliothek

The Deutsche Nationalbibliothek lists this publication in the Deutsche Nationalbibliografie; detailed bibliographic data are available in the Internet at http://dnb.dnb.de.

(C) 2014 Walter de Gruyter GmbH, Berlin/Boston

Typesetting: Dörlemann Satz GmbH \& Co. KG, Lemförde

Printing and binding: Hubert \& Co. GmbH \& Co. KG, Göttingen

$\infty$ Printed on acid-free paper

Printed in Germany

www.degruyter.com 


\section{Contents}

Silvia Polla, Philip Verhagen

Introduction . . . . . . . . . . . . . . . . . . . . . I

Dimitrij Mlekuž

Exploring the topography of movement . . . . . . . . . . . . 5

Gary Lock, Mariza Kormann and John Pouncett

Visibility and movement: towards a GIS-based integrated approach . . . 23

Élise Fovet and Klemen ZaKŠEK

Path Network Modelling and Network of Aggregated settlements:

a case study in Languedoc (Southeastern France) . . . . . . . . . 43

Philip Verhagen, Silvia Polla and Ian Frommer

Finding Byzantine junctions with Steiner trees . . . . . . . . . 73

Patricia Murrieta-Flores

Developing computational approaches for the study of movement: assessing the role of visibility and landscape markers in terrestrial navigation during Iberian Late Prehistory . . . . . . . . . . . . 99

Abstracts . . . . . . . . . . . . . . . . . . . . . . . .

Abbreviations . . . . . . . . . . . . . . . . . . . . . . . 

Silvia Polla, Philip Verhagen

\section{Introduction}

Within the framework of the Excellence Cluster Topoi, a fruitful interdisciplinary debate on space and movement over the long term has developed. The workshop "Computational approaches to movement in archaeology" (organized on January 620 II in Berlin) tackled questions related to space and movement in the framework of computational archaeology, landscape archaeology, historical geography and archaeological theory. The current volume, which is the product of this meeting, brings together contributions that show how the study of settlement patterns and movement has been dramatically transformed by the use of spatial technology (GIS), in particular Cost Distance and Least Cost Paths (LCP) Analysis. The term "least cost path" is somewhat deceptive, however, since it is not just the costs of movement, but also the benefits of moving to a particular location that influenced the routes chosen and created.

Archaeological theories about the way people moved in the landscape, and how they created and maintained paths and communication networks are often based on relatively abstract notions. For example, several papers in the current volume indicate that visibility may have been an important factor (co-)determining movement and path creation in the landscape. However, the exact parameters involved, and how they influenced the routes chosen, are largely within the realm of speculation. Computer-based modelling can be seen as a sophisticated approach to speculation. It allows us to experiment with the possible parameters involved, change the values and weights of each and inspect the outcome to see whether it conforms to our initial expectations and if it in some way fits the actual archaeological evidence. Most importantly, computer-based models are explicit: since all assumptions are laid out in detail, we can study the consequences of changing them, and the models can be replicated. It is through modelling that different scenarios can be explored and compared to real-world outcomes. Computer-based models are therefore in essence heuristic tools that can help to develop theory and interpretation.

The papers in this volume all share this perspective: path modelling is used not so much as a tool to reconstruct ancient routes, but rather to help the interpretation of existing or hypothesized pathways or to develop new theories about prehistoric movement. They discuss the theory and methodology of path modelling and use case studies to show the potential of their approaches for understanding factors and effects in landscape formation and transformation in the long term. The issues involved are complex, however, and the theoretical and methodological debate focuses on four main issues:

I. the extraction of indicators of accessibility and potential movement at different scales; 
2. model building procedures involving the choice of parameters and the definition of the cost functions;

3. the evaluation of the created models (best fit, deviations, required accuracy);

4. and network analysis approaches, especially concerning specific cultural contexts like Roman infrastructures and coherent road systems.

The interpretation of the generated models of networks and their relation to settlement patterns is concerned with time, scale and mobility issues, such as the type and purposes of movement and infrastructures, attractors of and barriers to movement. Continuity and change in settlement patterns can be studied by addressing the chronology and stability of paths and communication networks through a landscape archaeology approach.

The contribution by Dimitrij Mlekuž discusses the applicability of the concepts of time geography to issues of past movement. The theoretical framework he sketches is greatly influenced by postmodernist philosophy and by the notion of time in landscape archaeology studies. Movement is fluid, and constantly re-creates the material world. The dynamic nature of movement is problematic from a technical point of view, however. GIS-based mapping only offers a detached view, presenting fixed snapshots in time. Mlekuž argues that we can escape from this position by regarding computer-based models as practices that allow us to explore the connections between static representations and the flows and movements of people and objects in the past. Time geography is then used as a conceptual structure for creating "potential path areas," basically the area that can be reached within a certain travel time. This method creates what he calls a topography of accessibility. While not completely new from a technical point of view, the theoretical framework and the archaeological possibilities of interpretation that this approach offers are promising, since it relates standard cost surface calculations to issues of scale of movement (long distance versus daily practice) and strategic considerations in the placement of settlements.

The paper by Gary Lock, Mariza Kormann and John Pouncett focuses on the possibilities of integrating and better understanding the role of visibility in creating prehistoric pathways. Their paper is very much inspired by a post-processual, phenomenological theoretical framework, and is noteworthy for the attempt that is made to understand in detail what it actually means to include visibility in least cost path modelling, and how quantitative and qualitative approaches can be integrated in both method and theory. Lock et al. have developed a sophisticated multi-scalar approach to path modelling, based on viewsheds that take into account the distance to the horizon. Futhermore, the weight attributed to visibility as a factor influencing movement is modified according to the possible goal of movement: do people want to see around them, or do they want to avoid being seen? The resulting paths and interpretations, using a case study of Neolithic long barrows in England, show that path models should primarily be seen as tools for exploring the connections between the grave monuments and movement at what could be called a "phenomenological scale."

Lock et al.'s paper is strongly connected in methodology to the contribution of Élise Fovet and Klemen Zakšek. They use a different approach to modelling visibility, using the 
average angle of view rather than the distance to the horizon, but the aim is very comparable: to find out how visibility influences the location of the modelled paths. In their case, the interest is in reconstructing and interpreting the Roman road network in the Languedoc (France). In contrast to the first two papers, however, they are not particularly interested in the phenomenological aspects of movement, but much more in the long-term evolution of settlement patterns and communication networks, and the relations between settlement location and routes.

The paper by Philip Verhagen, Silvia Polla and Ian Frommer focuses more on methodological aspects of route modelling. In a similar vein to the previous two chapters, they try to reconstruct a Roman road section in Cappadocia (central Turkey) using visibility as a potential factor influencing road construction. To judge from the modelling results, however, this does not seem to have had a major influence. The Roman road network in the area was completely restructured during the Byzantine period. Instead of long-distance connections, shorter distance roads were constructed. One of the features of this more finegrained network of connections is that junctions are found in places where no settlement is present. Modelling the location of these junctions is not possible with standard GIS tools, however. Instead, an algorithm for creating junctions (so-called Steiner points) was experimented with, and resulted in modelled paths that are closer to the supposed location of the Byzantine roads than standard least cost path calculations.

The last chapter, by Patricia Murrieta Flores, examines in detail the role of navigation in movement, and specifically in the patterns of transhumance in the Copper Age of Andalusia (Spain). The presence of megalithic funerary monuments in the mountainous area of the Sierra Morena is taken as the point of departure for examining the possible role of these monuments as territorial markers that structured the seasonal movement of people and animal herds. The statistical analysis of the visibility of these monuments, in conjunction with the modelled natural corridors of movement, indicates that the megaliths may not have been navigational markers per se, but certainly marked vistas and may have been connected to a symbolic meaning as places of the ancestors, visited annually in the transhumance cycle.

As is evident from the contributions in this volume, path modelling is a subject that has proved to be one of the more challenging research topics within spatial analysis in archaeology. Considerable progress has been made over the past decade towards a better understanding of the mechanics of movement and in improving the methods to model this, and the archaeological implications of using path modelling are the subject of lively debate. So far the actual impact of path modelling in (landscape) archaeological research is still relatively limited, and its use has probably raised more questions than it has provided answers. In itself, this is not a development that we should be overly worried about. The use of new techniques and novel theoretical concepts will always open up new horizons as well as blind alleys and, from the successes and failures, fresh perspectives on the nature of (pre-) historic movement patterns, path finding and the development of communication 
networks will result. However, as the various contributions in this volume show, path modelling needs to be combined with well-framed archaeological research questions and supported by additional analyses to be used to maximum effect. And as long as path modelling still demands a relatively large investment in learning to master the technique and deal with the methodological problems, it will not become standard fare for spatial analysis a characteristic it shares with the related fields of visibility analysis and network analysis. A potential research agenda for the next five to ten years should therefore focus on the following major issues:

- improving the efficiency, flexibility and general ease of use of the available software solutions;

- developing methods and tools for better integration of path modelling with related fields like visibility analysis and network analysis;

- research into the mechanics of non-pedestrian movement, and the effects of other factors than slope on movement speed;

- developing better methods for testing the results of path modelling using archaeological data and theoretical concepts;

- and, finally, translating archaeological theory concerning movement and communication into terms that will allow for easier modelling.

We hope that the current volume may serve as a source of inspiration for archaeologists to follow up on these issues. We are convinced that path modelling will continue to be an exciting and fruitful area of archaeological research for years to come. 
Dimitrij Mlekuž̈*

\section{Exploring the topography of movement}

\section{Introduction}

Michel de Certeau, at the beginning of his groundbreaking essay "Walking in the City," climbs to the top of World Trade Centre to enjoy the view of New York laid out below (de Certeau i984). However, he notes that "to be lifted to the summit of the World Trade Centre is to be lifted out of the city's grasp." This is a privileged view, but one completely detached from the city below.

A city can exist only if there are people in it. The ordinary practitioners of the city are the pedestrians who make use of the spaces to walk, and they bring life to the city. Walking is "an elementary form of this experience of the city" (de Certeau I984, 94) and integral to this experience are walkers, "wandersmänner, whose bodies follow the thicks and thins of an urban 'text' they write without being able to read it" (de Certeau i984, 93).

Walking in the city turns out to have its own logic, or, as de Certeau puts it, its own rhetoric. The walker individuates and makes ambiguous the "legible" order given to cities by planners, which can be seen on maps or from above.

The same can be said for landscapes. Movement constitutes landscape; it is an essential act of weaving places into the web of landscape, making it real for the people themselves.

People also carry objects, moving them into new positional and relational contexts with other things, and they create new material encounters and new material traces through movement.

All of these parts are moving: movement suggests a continual process of becoming. Places are not so much defined by their location, their boundaries or shape, but through the flows and convergences that flow through them. Places are gatherings that are continuously on the move.

Movement is thus continuously generative and, if we want to understand it archaeologically, we need to develop approaches that can cope with the fluid conditions of these generative practices.

Representing movement, pinning it down on maps, has the effect of arresting movement outside the flows of its temporal and spatial contexts. Yet our discipline requires us to give movement an image. The common GIS approaches to movement are problematic, as they show not the emergent aspects of movement, but a detached view, de Certeau's view from above.

* University of Ljubljana. 
But that does not mean that our attempts to tackle movement in the past using computational approaches are missing the point. Attempts to represent movement should not be seen as points that record and communicate information about fluid and generative practices. Instead they should be seen as activities that contribute to the constitution of these fluid practices. Attention should shift from the image and its fidelity or treachery, towards practical relations and processes, which actively produce truths (Wickstead 2009, 254).

Computational tools help to articulate and express what we mean, because they are tools that help us to intertwine our practices of modelling with past movements. As Aldred and Sekedat (2011a) write, "an archaeology of movement should not exclusively focus on the captured image of representation, but also contend with the interdependent and emergent meanings that arise during intervention."

This paper is thus an attempt to approach movement from a computational perspective, creating tools that can help us cope with the fluid and emergent nature of movement, but instead of producing fixed representation in maps, we should see them as practices open-ended, processual, explorative activities - which do much more than resemble: they take the places of the original situation and thus enable us to intertwine our practice of modelling with the flows and movements of the past.

\section{Time geography}

In movement, issues of temporality, spatiality and practices are dialectically woven together and inseparable. All these issues are addressed holistically by time geography, as developed by Torsten Hägerstrand and his associates at the University of Lund in the I970s (Hägerstrand I970; I973; I975; I976; Pred I977). Time geography is a powerful conceptual framework for understanding human practices in both time and space, and, in particular, constraints and trade-offs in the allocation of limited time among practices in space. Time geography focuses on constraints imposed by the corporeality of human existence in time and space, such as the fact that no-one can be in two places at the same time, that everyone has only limited ability to undertake more than one task at a time, that movement is time consuming and "the fact that every situation is inevitably rooted in past situations" (Hägerstrand i975; Pred i977).

Time geography has developed a series of analytical instruments to investigate how certain types of constraints have a structuring effect on everyday life. The most fundamental concept of time-geography is time-space, or the time-space aquarium, a bounded threedimensional space where width and length describe two-dimensional space, and depth stands for time. The time-depth of the aquarium may vary, from daily or yearly, or a biographical, lifelong time scale.

Any physical body (a thing, substance, animal or human person) within the time-space aquarium can be described by its time-space path or trajectory, which describes its, his or 
her position and movement within the time and space. Thus, in time geography, time and space are inseparable.

However, much more interesting than isolated paths of agents are the time-space patterns, that emerge from interactions and relations between agents. This "choreography of existence" (Pred I977) emerges when the movement of agents on their daily practices forges a web of relations between them that serve as further constraints. Thus, for example, to join in a shared activity, two or more agents form a group and their time-space paths join at some place. The availability of material, tools and equipment is a further constraint on where this place could be. Through such an activity, systems emerge: these are stable, multi-scalar spatiotemporal patterns formed from the intertwined allocation of time among practices in space. Thus, in time geography, movement is not understood in isolation but instead as a component in a wider pattern of interaction, as "the glue in connecting" as Aldred and Sekedat (20Irb) put it.

The landscape - the relation between things where agents move around actively interacts with the capabilities of agents and thus plays an active role in the shaping of the paths. Hägerstrand (I976, 332) calls it the "principle of togetherness;" this is not, he writes, "just resting together. It is also movement and encounter ... because what is all the time resting, moving and encountering is ... humans, plants, animals and things all at once." Thus movement is the intertwining of many lines that run concurrently, making it a generative and recursive practice.

\subsection{Time geography and archaeology}

Matters become more complicated if we try to apply time geography to archaeological problems. Due to the fragmented nature and resolution of the archaeological record, the direct applicability of these concepts to archaeology is extremely limited. Except in outstanding cases, it is impossible to trace a time-space path of persons in the past. However, Hägerstrand and other time-geographers point to the regularities in movement when people carry out their everyday tasks or projects, which emerge as an activity system. Activity systems are patterns of daily, seasonal or lifetime routine movements, interactions and activities by agents. Practices can thus be understood as material bodies of work that have gained enough stability over time, through the establishment of corporeal routines and specialized devices, to reproduce themselves (Thrift 2007, 8).

Different persons tend, for various reasons and in various temporal scales, to move regularly in similar paths in time and space, for example going to work in a field, travelling to market, herding sheep, etc. Social practices or routines are normally conducted at definite places and at given moments ("stations," in time geography speak) although some may extend over long periods of time. Thus social individuals tend to follow recurring timespace paths in their day-to-day lives. Routine practices are shaped by various forms of con- 
straint, for example the need for regular sleep and food, the seasonal requirements of plants or animals, the availability of tools, the availability of other agents who form activity bundles, constraints imposed by the landscape itself, etc.

The routine practices of course also change the places where they occur; they leave material traces that create new constraints in the process. In this way they have structuring effects on future practices that will occur at the station or in the vicinity. Every movement changes the relation between things (Fahlander 2003, I22-I32). As Julian Thomas (I996, 90) puts it: "[w]hile people often move in cyclical patterns in the course of routine activities, returning to the same location again and again ... the places ... are themselves continuously being physically altered and decaying, as well as continuously being re-evaluated and re-interpreted."

The archaeological record is of course not a result of acts derived from a single person, but the cumulative effect of practices, brought into new relations with our own practices of archaeological work. Agents on their daily routines have shaped and changed the landscapes over a long time. The settlement then becomes the material residue of a bundle of special activities, which in turn has enabled other activities to occur in its vicinity, including the work of archeologists. Thus place is not an accretion of traces over time, but a complex set of spatial relations in a temporal setting, derived from the movement through it (Aldred / Sekedat 20irb).

We can thus see the landscape as a network of places, which are constantly reproduced as "collapsed acts" of persons moving and performing routines in time and space. This is close to Tim Ingold's (1993) relation between the "taskscape" and landscape: "just as the landscape is an array of related features, so - by analogy - the taskscape is an array of related activities."

This forces us to explicitly address the notion of time, which in this case is not just the simple linear succession of events, but is itself structured and shaped by the performance of tasks and produces different "temporalities," which are "collapsed" into landscape. Thus "[l]andscape is time materialized. Or, better, landscape is time materializing: landscapes, like time, never stand still" (Bender 2002, I03).

Landscapes are in a constant process of becoming (another temporality) through the daily, seasonal or biographical time-space "ballet" of actors. The routine practices in the landscape thus have structuring effects, which can be seen in the material record. As people move around in their daily practices, they make landscapes and make time go on. 


\section{Topography of accessibility}

\subsection{Time-space prisms}

How can these fluid, generative, continuous, aspects of movement be tackled using GIS? In archaeological analyses, past movement is usually modelled using cost surface generation and the computation of "least cost" pathways between given locations in the landscape. A cost surface is a continuous surface in which each part of the landscape (i.e., raster cell) represents the cost, or "price" to reach that point from a source point. Cost is computed from the distance and "friction" or difficulty of moving across the raster cell is expressed either as time or caloric expenditure. Thus price can be expressed as an accumulated friction (Bell / Lock 2000, 86). Least cost pathways between the source of cost surface and target are traced by using some kind of optimizing algorithm (usually a derivate of Dijkstra's shortest path [I959] algorithm). The shape of the computed path is extremely sensitive to the algorithms used and so least cost pathways can diverge significantly.

The typical applications of cost surface analyses in archaeology, for example analyses of site catchments, least cost paths etc., usually implicitly or explicitly invoke theoretical assumptions such as rational behavior and the least cost principle, as the name "least cost analysis" implies.

Thus an "optimal path" is represented as a static map, line or series of points which connects the departure and destination points. It looks very precise, but its accuracy is questionable.

A more general use of "optimal paths," which is in many ways similar to approach outlined in this paper, was attempted by Marcos Llobera (2000). His approach focuses on a general pattern of movement in the landscape rather than specific pathways, and he explicitly approaches movement as a vital element of social landscapes.

We argue that cost surface analyses can have a much more general analytical use in archaeology. We turn for inspiration to time geography.

The future paths of a past agent located somewhere in space can potentially branch off in a number of directions. However, they are limited by constraints working on them, such as maximal speed, availability of transport, etc. The time-space prism circumscribes a timespace volume where all trajectories must or can progress. Its shape is defined by constraints that operate on the individual. The prism thus discloses possibilities, and focuses on these rather than on behaviour per se. This renders the concept neutral and universally applicable, as it articulates a fundamental coherence in our world (Lentrop 2004).

The time-space prism can exist between any pair of temporally adjacent points. In this case, there is an open temporal interval - "time budget," in time geography parlance - during which the person can conduct travel and participate in activities. More generally, one or both of the origin or destination points may be unknown, or they may be different locations. Projecting the time-space prism onto the two-dimensional geographic plane de- 


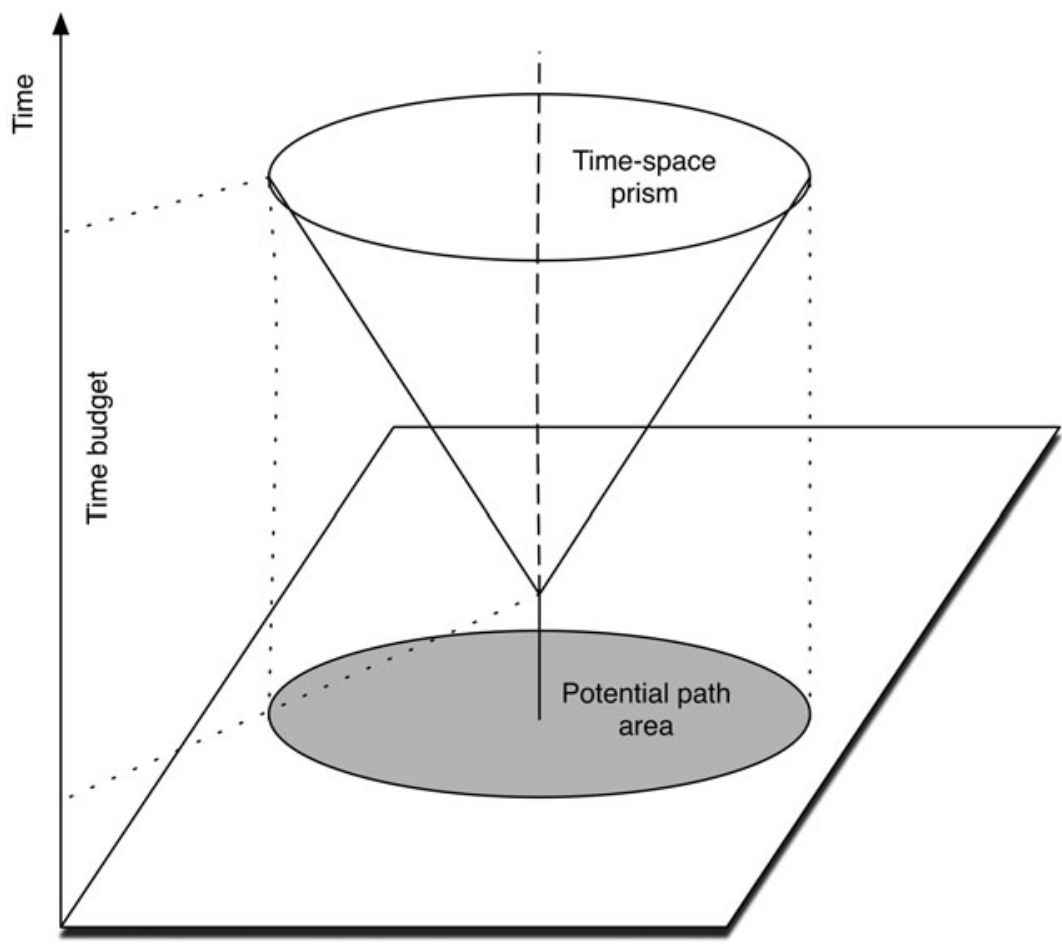

Space

Fig. 1 | Time-space aquarium with time-space prism.

limits the potential path area, that is, the set of geographic locations that the person can occupy during the available time budget. The potential path area is a binary map, where values indicate presence inside the projected time-space prism.

The cost surface, where the cost represents the travelled time from the starting point, is an equivalent of the surface of the time-space prism with one known and one unknown point. We might call it the future surface, as it represents the time-space surface of maximal possible extent of an agent at a given time after she departs from the starting point. In the case that the point represents the known end-point, the cost surface represents the past surface, or possible locations at a given time before she reached the destination point (Miller 2005).

Most of the widely used cost surface analyses in archaeology, for example the delimitation of isochronous surfaces around sites (Gaffney and Stančič 1993), are therefore potential path areas of prisms, where agents return to their destination points within a given time budget. These analyses can of course be produced using ready-made capabilities offered by standard GIS packages.

Potential path areas are the most general way of describing movement. They focus only on constraints that operate upon the moving actor. In this way they show where 
movement could occur, given the constraints. It is extremely imprecise, but also very accurate.

However, there are also some more exciting uses of potential path areas, which can yield a more complex or deeper understanding of the social processes in the landscape and tell us more about how people move around and perceive the landscape.

We can combine potential path areas in a new map by adding different potential path areas from a set of starting points. In this way we get cumulative path areas. The value of every cell in the cumulative path area map indicates from how many starting points it is accessible within the allocated time budget. By modifying the time budget we can observe the effect of it on the structure of possible interaction in the landscape. Thus we can measure the accessibility of parts of the landscape from the different sites or bundles of activities. Its shows how the places change the structure of the landscape, and can identify the places or areas where interaction is facilitated by the landscape, where bundles of activities can occur and where not, or where a larger time budget is needed to form a bundle. It can also help the identification of "non-events," or better, the barriers that prevent certain types of activity from occurring (Pred I977, 210).

\subsection{Potential path field}

The idea of cumulative path area can be expanded to include every point in the landscape. The potential path field is thus a sum of potential path areas within a given time budget from every location in the landscape. Thus the potential path field is computed by adding potential path areas from every location in the landscape within the given time budget. The result is a continuous raster surface, where the value of each cell informs us from how many points within a given time budget it is accessible (Fig. I). Every point will have a value of at least I, as it is accessible from itself, but usually a much higher value. Points with higher values are accessible from more locations within the same time budgets, or to turn it around, they can access more locations than points with a lower count.

Potential path fields are computationally extremely intensive. The results also suffer badly from the boundary effect, which means that the values at the edges of study area do not provide real values.

Potential path fields are at first difficult to interpret. They give a cumulative overview of accessibility, and do not describe specific acts of movement, or movement from a specific location. They therefore yield a new idea of landscape, based on its accessibility. We can also call it the topography of accessibility. It thus identifies areas that are more accessible and so shows the structuring potential of the landscape itself on the movement and practices in landscape.

By varying the time budget we can explore the relation between time and the structuring effect of the landscape (Fig. 2). The topography of accessibility is highly dependent on 
time budget. With a limited time budget, absolute values are generally small, as one can access only a limited number of locations from each spot. Local differences thus have a huge effect on the topography of accessibility. Differences between close locations are therefore sharply pronounced. Topography of accessibility with a small time budget shows finegrained differences in accessibility. As time budget increases, the topography of accessibility becomes absolutely higher, but more and more smoothed out and less grainy, as close locations become more and more similar in terms of accessibility. We can observe the emergence of large-scale patterns, such as accessibility basins, barriers and corridors.

Varying the available time budget allows us to explore how time spent performing practices changes the way people interact and access the landscape. Thus locations with good accessibility on a small time budget do not necessarily have good accessibility when the time budget is increased. The landscape activities that require more time (for example, going on pilgrimage, transhumance, trade ...) structure or define landscape in completely different ways from practices of short duration (for example, daily activities, going to the fields, herding sheep, carrying substances to a house ...). Landscape, at least from the perspective of accessibility, is therefore constructed from practices that are performed in it.

Thus, in addition to busier areas in the landscape, we should also expect to find nonplaces and back-areas. We can measure how accessible parts of the landscape are, where interaction is facilitated by the landscape, where bundles of activities can occur and where not, or where a larger time budget is needed to form a bundle. In this way we can see landscape as a vehicle for interaction, and the ways daily practices structure the long-term material record in the landscape.

In short, the potential path field or topography of accessibility shows how the topography affords interaction and access on different time scales, or how landscape facilitates and is structured by practices. In this perspective, landscape becomes a very dynamic and fluid thing. Practices that differ in their term of duration or available time budget create different landscapes.

The potential path field is in many ways similar to Marcos Llobera's (2000) topographic accessibility index (or total path cost). His index is computed by summing all optimal paths from each cell within a given neigbourhood to a destination cell, for each location (cell) in the landscape. However, the potential path field, being developed from the perspective of time-geography, explicitly references time as the main constraint that limits the movement and interaction in the landscape. Here, movement is approached in the most general way, through time-space prisms expressed as cost surfaces, making the potential path field a more general and robust index than Llobera's approach, which focuses on the specific paths. 

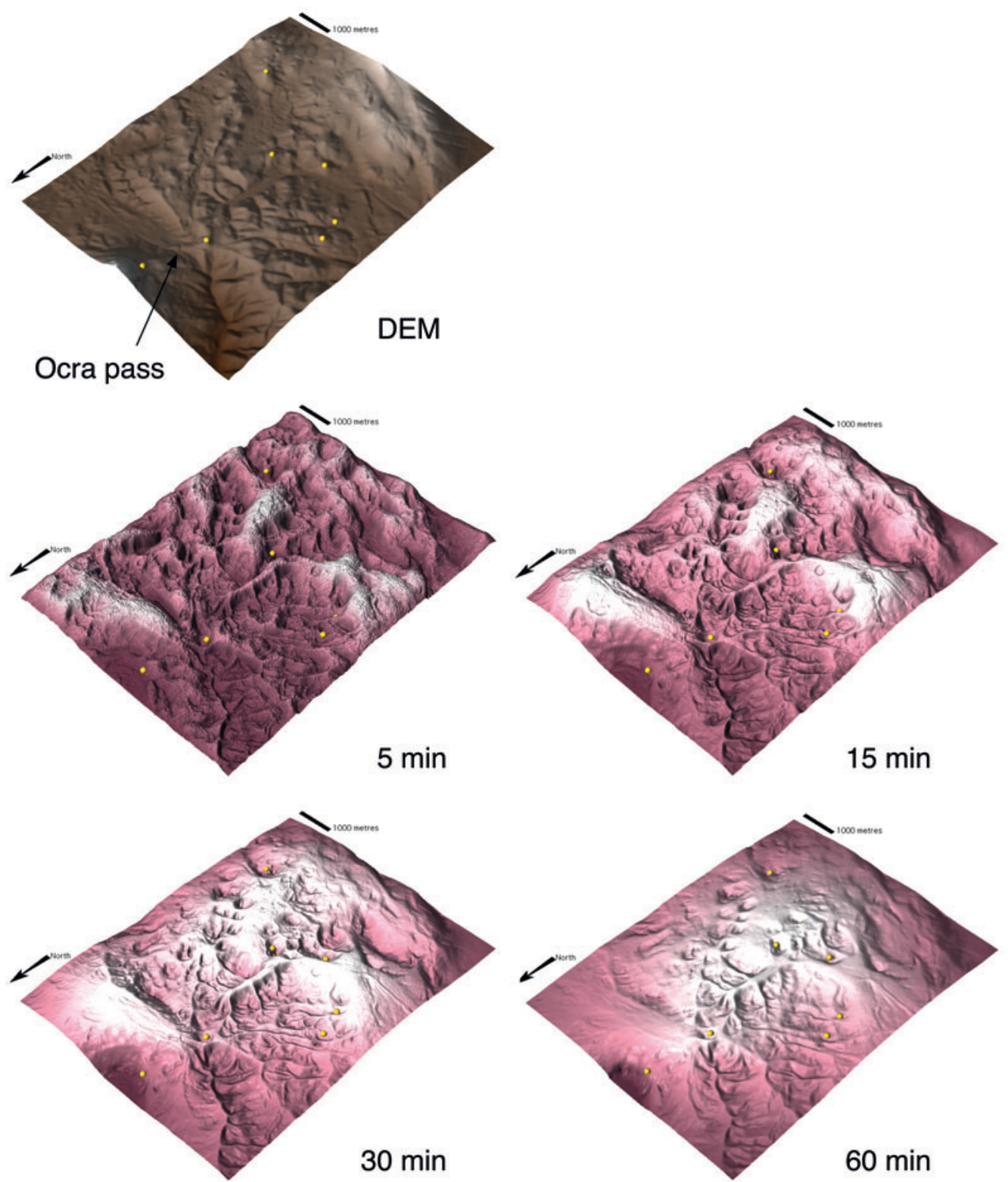

Fig. 2 | Digital elevation model of the study area and topographies of accessibility for different time budgets. 


\subsection{Working with the topography of accessibility}

The potential path field or topography of accessibility measures the connectedness of each cell to other cells reachable within the time budget. Higher on the topography of accessibility, more places become accessible within the given time budget: climbing the high ground one gets better access to the places within the time budget; staying on the high ground maintains good access to other places within the time budget, meaning that travel on the high ground is fast. Cells positioned high on the topography of accessibility are thus candidates for paths, corridors and routes.

If we see the potential path field as the topography of accessibility, we can analyse the topography of accessibility using morphometric parameters such as slope, aspect and other features (Hengl / Reuters 2009).

Thus the slope of topography of accessibility (or first derivate of the potential path field) gives us the change in speed. In steep areas travel slows down or speeds up, depending on whether one is travelling up or down on the topography of accessibility. The steeper the slope, the larger is the change in speed. "Flat" areas indicate areas where speed of movement is constant (Figure 3).

The aspect of the topography of accessibility is the direction where the change in accessibility is largest.

Using morphometric tools, the topography of accessibility can be subdivided into features such as pits, peaks, channels, ridges, passes and planes. The names of features suggest a geomorphological interpretation, but they must be understood in terms of rates of change of three orthogonal components of the potential path field. Pits are the locally least connected cells, while peaks are the locally best connected ones. Ridges connect points with good accessibility, making them natural corridors for movement. On the other hand, valleys are poorly connected, backwater areas. Saddle points are points between two ridges, points or areas where backwater areas can be crossed. In this way they can be seen as bottlenecks that funnel movement. Plains are areas where speed of movement is constant (Fig. 3).

A prominence filter (Llobera 200I) reveals the difference of accessibility between the point and other points in the landscape within the arbitrary neighbourhood. The accessibility prominence is defined as the percentage of locations that are less accessible than the individual's location within a certain radius. In this way a prominence filter isolates parts of the landscape within the neighbourhood that are more accessible within the specific radius, that is, locations that are better connected than their neigbours. Landscape is then structured into a network of well-connected locations and islands of backwater locations (Fig. 3).

All these analyses make it possible to explore how landscape is structured into pockets of backwaters and corridors of movement on different temporal and spatial scales. All these more or less distinct features, places or locales may be important for 


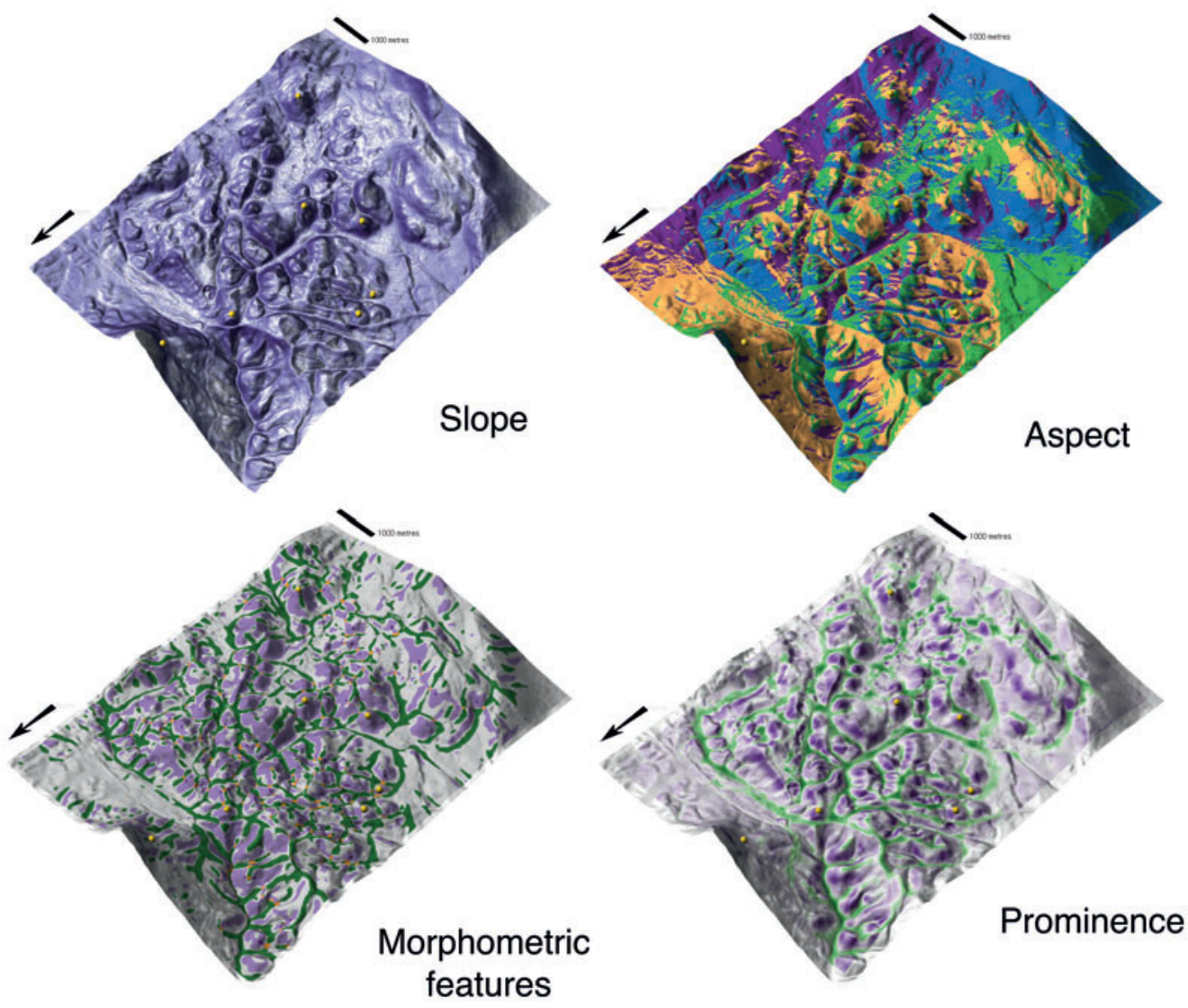

Fig. 3 | Morphometric analyses of the topography of accessibility.

understanding how people really move around the landscape and how they perform activities there. In a time geography perspective, such places and features can function as corridors, which channel the flow of movement, structure daily practices and enable bundles of activity to occur.

\section{Instead of a case study: Spatial strategies and tactics around the Ocra pass in prehistory}

How can these tools be used to understand past movement? Instead of a full-fledged case study we present a preliminary sketch that highlights the contributions of the new tools to the understanding of various practices in the landscape. We demonstrate how these tools 

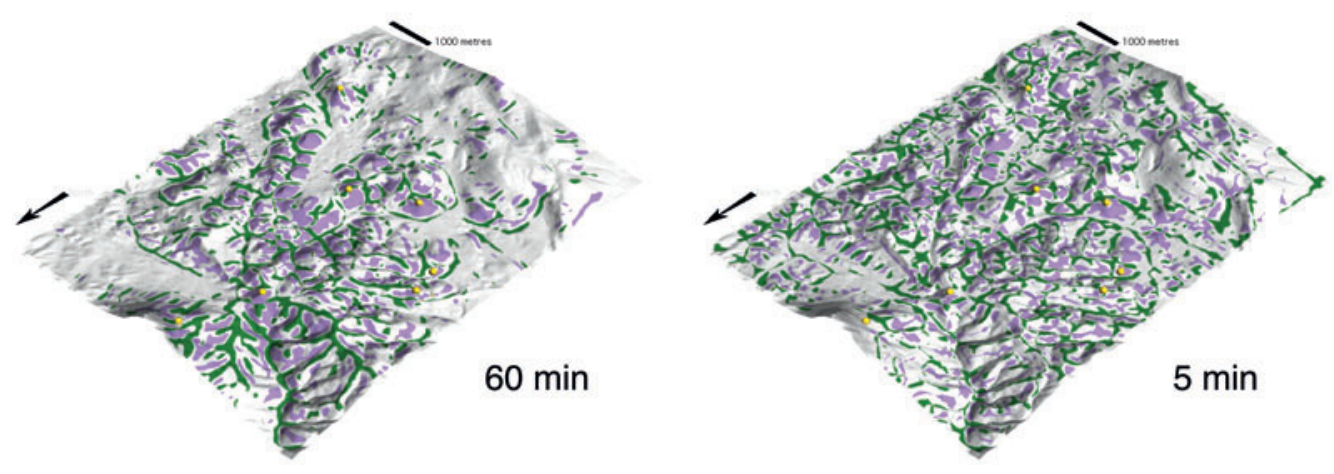

Fig. 4 | Morphometric features of the topography of accessibility of the study area on a 60 minute and a 5 minute time budget.

can be used in a more nuanced and open-ended exploration of past practices in a land-

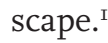

Razdrto, or Ocra, as it was called in classical sources, is a pass around $597 \mathrm{~m}$ a.s.l. crossing the Dinaric Alps (Alpes Iuliae in classical sources) in western Slovenia. Ocra is the gateway between the Mediterranean and Central Europe. Here, two old long-distance channels funnel: the Amber Route connecting Adriatic Sea with the Baltic Sea, and the route to the Black Sea, from where Argonauts came on their mythical journey from Colchis.

In the Bronze and Iron Ages a series of hillforts was constructed in the region, some of them directly overlooking the pass. Roman transport across Ocra increased by the mid-2nd century BC, after the establishment of the colonia Aquileia in the Friuli Plain. In the Augustan period, a road was built, which connected Aquileia with the Roman town Emona (Horvat / Bavdek 2009).

How can we approach the area of the Ocra pass in terms of mobility? Surely there is no need to tackle obvious paths and corridors. The pass, which "naturally" channels the movement, is very obvious, as are the very easily observed general corridors to and from the pass (Fig. 2, 3 and 4).

The 6o-minute potential path field clearly includes areas with long-distance, or longterm accessibility, areas which are very well connected with distant locations (Fig. 4). It shows the main corridors where people and things can flow relatively fast and unhindered by topography. This is accessibility in terms of fast movement across the landscape and not in the landscape.

I For this study, a DEM (digital elevation model) of the $60.5 \mathrm{~km}^{2}$ study area with the spatial resolution of $\mathrm{I} 2.5 \mathrm{~m}$ was used. Friction surface was computed using Tobler's hiking formula (Tobler 1993) and expressed as minutes needed to cross the raster cell. All calculations were performed using scripts developed for GRASS GIS. 
The establishment of hillforts around the main corridors is thus an element of a plan to control and channel the flow of people and material across the pass. The communities who built them created new spatial arrangements, which were made to control and dominate the passage of the material and people across the pass.

This obvious, visible spatial arrangement can be identified with what de Certeau calls "strategy." For de Certeau (1984), power is about territory and boundaries, in which the weapons of the strong are classification, delineation, division and control, while the weak use furtive movement, short cuts and routes (his term is "tactics") to contest this spatial domination.

Strategies are only available to subjects of "will and power," so defined because of their access to a spatial or institutional location that allows them to objectify the rest of the social environment. Strategies thus invoke and actualize a schematic and stratified ordering of social reality.

The position of hillforts around the obvious channels and corridors is thus a strategy, by which established centres of power are made concrete in hillforts in relation to the flows of material across the pass.

As we decrease the time budget, to 5 minutes for example, a more surprising picture emerges. The landscape composed of major corridors fragments into a mosaic of smallscale paths and routes outside the grand corridors (Fig. 4). There is no longer a single, wellordered landscape structured around the main corridors of movement, but a chaotic, unordered landscape. In De Certeau's terms, this is the space of "the tactic," an action that he defines as insinuating itself within the space of the other, worming its way into the territory of that which it seeks to subvert. It claims no space for itself, relying rather on time - "it is always on the watch for opportunities that must be seized 'on the wing'” (de Certeau I984, xix).

Thus we see a web of possible movements, crosscutting the structure ordered by intercommunity politics and power, materialized in the hillforts. It is the place of daily action, of the practices of people doing their daily chores outside the domain of politics and large structures of power.

These places possibly never materialized into structures like paths, as the gains from their small-scale victories are always discarded, "whatever it wins, it does not keep" (de Certeau I984, xix). A tactic is to infiltrate into the other's place, always on the watch for opportunities in time. For de Certeau, this is the central feature of everyday life, which "poaches" in countless ways from the property of others. People appropriate and reappropriate the strategic structures, in order to manipulate and enjoy them. The hillforts make sense only in relation to the large channels of movement, that is, movement in terms of long-distance communication, transport and exchange. When we get down to the tactics of daily practices, however, the whole landscape, ordered and constructed by the logic of power and control, fragments into the landscape of daily practices. The daily practice of walking subverts the logic of control and domination. 
In this way we can explore the ways people resist the spatial discipline imposed by communities. This "imprint of walking" breaks down the logic of domination through the spatializing practices of everyday living.

It is ultimately the people, on their daily tasks, who create landscape. As with de Certeau's walkers in the city, landscape is created by daily tasks in the landscape and not by large-scale plans and ideas. Landscape is not a plan laid down by strategies of control and domination, which forces people into predefined channels of movement. Ultimately it is people who trace or do not trace these corridors, using their tactics to avoid them or subvert them for their own purposes.

\section{Conclusions}

As people move through the landscape, so they define it: there is no landscape without people moving around on their tasks. People create the space to move through as they move through it, and their movement creates time as well. The real challenge facing archaeological GIS research lies in the development of concepts, tools and approaches that can enable us to analyse and understand the complexities of past human engagements with the world. Time geography offers a conceptual and methodological framework for conducting accessibility constraint analyses that can be implemented within GIS.

Time geography focuses on time, space and practices, and places the emphasis on the significance of the material world and its constraints. Time geography is not limited to the mere description of courses of events in time and space, but emphasizes the importance of gaining a deeper understanding of fundamental social conditions and processes (Lenntrop 2004, 223). The approach outlines necessary but not sufficient conditions for human interaction. Thus it provides an approach rather than a full theory and requires the utilization of other knowledge and theoretical frameworks. We see this as its this major strength, as it does not come loaded with theoretical baggage, but can be employed as an analytical tool within many different theoretical approaches towards past landscapes.

By focusing on the human interactions afforded by time and space, it allows us to approach the landscape as an agent of interaction between people. A time-space framework can help us to understand the limits time and space impose on interaction between people. It tells us about possibilities and nothing more. It does not offer spatially precise but nonaccurate results, such as are provided by least cost paths.

Finally we want to stress that our tools do not produce non-problematic representations of movement, as end-points that record and communicate information about movement: paths, roads, corridors ... We believe that those representations would ultimately be misleading and wrong. Instead, these tools should be seen as explorative activities, that do much more than just resemble: they take the places of the original situation and so enable us to intertwine our practice of modelling with the flows and movements of the past. The 
difficult task of figuring out what happened within those possibilities is thus left to the interpretative skills of archaeologists.

\section{Acknowledgements}

This research was conducted while I was Marie Curie fellow at Ghent University. I would like to thank Patricia Murrieta-Flores for insightful discussion about computational approaches to movement. All mistakes, however, remain my own.

\section{References}

Aldred, O. / Sekedat, B. (20Ira)

Part 2 of Moving on to Mobility: Archaeological Ambulations on the Mobile World. http:// traumwerk.stanford.edu/archaeolog/20II/oI/part_2_of_moving_on_to_mobilit.html (seen I6. I2. 20II)

Aldred, O. / Sekedat, B. (20IIb)

Part 4 of Moving on to Mobility: Archaeological Ambulations on the Mobile World. http:// traumwerk.stanford.edu/archaeolog/20II/05/part_4_of_moving_on_to_mobilit.html (seen I6. I2. 20II)

Bender, B. (2002)

"Time and Landscape", in: Current Anthropology 43, I03-IO2.

Bell, T. / Lock, G. (2000)

"Topographic and Cultural Influences on Walking the Ridgeway in Later Prehistoric Times", in: G. Lock (ed.), Beyond the Map: Archaeology and Spatial Technologies, Amsterdam, 85-100.

de Certeau, M. (1984)

The Practice of Everyday Life, Berkeley.

Dijkstra, E.W. (1959)

"A Note on Two Problems in Connection with Graphs", in: Numerische Mathematik I, 269-271.

Fahlander, F. (2003)

The Materiality of Serial Practice: A Microarchaeology of Burial. PhD dissertation, Göteborg.

Gaffney, C. / Stančič, Z. (1993)

GIS Approaches to Regional Analysis: A Case Study of the Island of Hvar, Ljubljana.

GRASS Development Team (2012)

Geographic Resources Analysis Support System (GRASS) Software, Version 6.4.2. http:// grass.osgeo.org (seen I3. 3. 20I3) 
Hägerstrand, T. (1970)

"What About People in Regional Science?", in: Papers of the Regional Science Association 24, $7-2 \mathrm{I}$.

Hägerstrand, T. (1973)

"The Domain of Human Geography", in: R.J. Chorley (ed.), Directions in Geography, London, $67-87$.

\section{Hägerstrand, T. (1975)}

"Space, Time and Human Conditions", in: A. Karlqvist / L. Lundquist / F. Snickars (eds.), Dynamic Allocation of Urban Space, Lexington, 3-I4.

\section{Hägerstrand, T. (1976)}

"Geography and the Study of Interaction between Society and Nature", in: Geoforum 7(5-6), 329-334.

Hengl, T. / Reuter, H.I. (eds.) (2009)

Geomorphometry: Concepts, Software, Applications, Amsterdam.

Horvat, J. / Bavdek, A. (2009)

Ocra, The Gateway between the Mediterranean and Central Europe, Ljubljana.

Miller, H.J. (2005)

"A Measurement Theory for Time Geography", in: Geographical Analysis 37, I7-45.

Ingold, T. (1993)

"The Temporality of Landscape", in: World Archaeology 25(2), I52-I74.

Lenntrop, B. (2004)

"Path, Prism, Project, Pocket and Population", in: Geografiska Annaler, series B, 86/4, $223-226$.

Llobera, M. (2000)

"Understanding Movement: A Pilot Study towards the Sociology of Movement", in: G. Lock (ed.), Beyond the Map: Archaeology and Spatial Technologies, Amsterdam, 65-83.

Llobera, M. (200I)

"Building Past Landscape Perception With GIS: Understanding Topographic Prominence", in: Journal of Archaeological Science 28, 1005-IOI4.

Pred, A. (1977)

"The Choreography of Existence: Comments on Hägerstrand's Time-Geography and its Usefulness", in: Economic Geography 53(2), 207-22I.

Thomas, J. (1996)

Time, Culture, and Identity, London.

Thrift, N. (2007)

Non-Representational Theory, London. 


\section{Tobler, W. (1993)}

Non-isotropic Geographic Modelling (National Center For Geographic Information and Analysis, Technical Report No. 93-I), Santa Barbara, CA.

Wickstead, H. (2009)

"The Uber Archaeologist. Art, GIS and the male gaze revisited", in: Journal of Social Archaeology 9(2), 249-27I. 

Gary Lock, Mariza Kormann, John Pouncett**

\section{Visibility and movement: towards a GIS-based integrated approach}

\section{Introduction: why visibility and movement?}

A continuing theme since the initial adoption of GIS technology by archaeologists has been the modelling of visibility and movement as ways of understanding past landscapes and the people who inhabited them. The underlying issues have been fully explored elsewhere (Lock / Pouncett forthcoming) and here we briefly introduce only the main points relevant to the work presented in this paper. Modelling visibility and movement is usually justified through an interest in "perceiving the landscape" and an attempt to move GIS-based analysis away from "detached objectivism" (describing landscape as if viewing from a distance) towards "situated subjectivity" (trying to understand landscape from experiencing it directly).

From the earliest publications on archaeological GIS, the potential of modelling visibility and movement has been recognized. In his introduction to Interpreting Space, for example, Green talks of "perceiving landscape" and how "GIS provides such a means" (Green I990, 6), while within the same volume Madry and Crumley (I990) present an example of GIS being used to explore the landscape settings of sites through viewshed analysis and the calculation of least cost pathways. The critique of GIS as encouraging retrogressive positivist approaches, a situation that was recognized and criticized early within the adoption process (Wheatley I993; Gaffney / van Leusen I995), led to a greater reliance on visibility and movement studies as the main outcome of this humanist turn. Consequently both techniques have been developed considerably, with visibility studies refined to include cumulative, Higuchi and directional viewsheds (Wheatley / Gillings 2000), and movement studies similarly refined to include various sorts of surface approaches, not least accessibility (Llobera 2000).

To use visibility or movement is now almost de rigueur in archaeological applications and it is the "or" that we wish to address here. Both approaches are seen as a way of humanizing digital models, avoiding the detached, "seeing everything from above" view of the world and situating the agent within the landscape. There is, of course, a strong whiff of technological determinism surrounding these techniques, as both are relatively easy to perform as individual functions without any understanding or discussion of the underlying technical or theoretical assumptions. The theoretical shortfall here is that for human beings movement and visibility are not separate "procedures" or "functions" but are intimately linked to produce the world as we perceive it.

* University of Oxford. 
Here we draw heavily on the theoretical work of Gibson (I979) and Ingold (2000; 20II). Gibson, a psychologist specializing in visual perception, argued that movement and visibility are interlinked and that we engage with landscape through a constantly changing series of vistas, his theory of "reversible occlusion." He also introduced the concept of "affordance," whereby landscapes depend on the interaction of perceiver and environment, which come together to offer opportunities for action. For example, gentle slopes afford movement whereas a sheer cliff does not. Ingold has added a phenomenological interpretation to Gibson's ecological approach to visual perception: he argues that visual perception never occurs from a fixed point but through a "continuous itinerary of movement," so the "unfolding of a field of relations [is] established through immersion within an environmental and social context." This also introduces the importance of the "social context" in addition to the environment: cultural markers within the landscape assume extra significance as influences on movement. In this paper we are inspired by, and try to model, several of Gibson's and Ingold's concepts based on the notion that movement is primarily visual. This moves us away from the well rehearsed arguments of space versus place, where the concept of "place" is a culturally constituted but essentially static understanding of the world, and towards one based on pathways, wayfinding and life as a constantly changing network of cultural and ecological experiences that are lived through moving.

Central to this approach, and to using GIS technology more widely, is an understanding of "scale," a surprisingly complex and slippery issue often taken for granted and not well theorized or often discussed in depth in GIS-based archaeology (Lock / Molyneaux 2006). Here we recognize two different forms of scale (Dobres 2000), "analytical scale" and "phenomenological scale." Analytical scale is the realm of research, the recognition, measurement and analysis of patterns, including operational concepts such as ratio, fraction and spatial resolution. Phenomenological scale is the lived scale of being in the world and experiencing embodied interactions with the material world as part of everyday life. This difference reflects the quantitative/qualitative tension present in archaeological GIS and is something we try to address in this paper through the integration of method and theory.

\section{Previous work: hillforts of the ridgeway}

This paper builds on previous work that explored various methods of modelling visibility and movement along the Ridgeway, a prehistoric pathway in central England, and its relationship with a series of Iron Age hillforts (Bell / Lock 2000; Lock / Pouncett 20I0). The earlier paper combined two elements: the use of least cost pathways (LCPs) to determine the possible route of the Ridgeway in later prehistoric times, and viewshed analysis to determine whether the hillforts were located to be visible from the Ridgeway. The initial LCP calculated from a cost surface based solely on a function of slope - an unconstrained LCP - 
"fell off" the Ridgeway following the initial path of least resistance. Because the Ridgeway runs east-west along a ridge top, it was decided to add a topographic bias which would more accurately model the human intentionality of walking the path, in effect attempting to model human behaviour rather than the behaviour of an algorithm. A function of aspect was added which prioritized east-west movement by decreasing the friction costs as the aspect approaches $90^{\circ}$ and $270^{\circ}$ to the path. The resultant constrained LCP approximately followed the modern Ridgeway and formed the basis for further analysis.

A series of binary viewsheds were generated at $250 \mathrm{~m}$ intervals along the Ridgeway with a maximum viewable distance of $3 \mathrm{~km}$ in order to model near and middle distance visibility as someone walked along the Ridgeway. Viewsheds were accumulated to produce a visibility index and the location of hillforts was tested against the high visibility areas, in order to establish whether they were located to be visible, which, as it turned out, they aren't. This analysis highlighted the influence of topography for modelling movement and the importance of scale for modelling visibility. The second paper developed these themes further, introducing a multi-scalar approach which sought to better integrate modelling of movement and visibility through the concepts of corridors of intentionality, reflecting the long distance aim of moving from Point A to Point B, and intermediate waypoints, from Point A to Point B via Point C. These were underpinned by the concept of "affordance," highlighting the relationship between the perceiver or active observer and the environment, and were intended to shift the emphasis of modelling movement away from the "efficiency" of accumulated costs towards the human intention that underlies movement.

Slope is scale-dependent and, therefore, so too are any costs based on slope, and the LCPs which are generated on the basis of the accumulation of those costs. Landserf (Wood I996) was used to calculate slope for multiple scales of analysis, ${ }^{\mathrm{I}}$ using window sizes to a maximum of Io I cells (equivalent to a planimetric distance of circa I km). Marked variation was observed in the LCPs for different scales of analysis, with changing correlations between the LCPs and the Ridgeway in areas of varying topographic definition. Different topographic features were picked out at different scales of analysis, with some LCPs following the line of the Ridgeway closely and others picking out passes or cutting across the heads of valleys. Additional complexity was added to the movement algorithm to incorporate a function of visibility based on cultural landmarks being visible as waypoints along the intended route. Corridors of intentionality were defined for each leg of the journey using directional binary viewsheds for a corresponding cultural landmark, in this case an intermediate hillfort. "Cones" of vision were calculated by inverting the direction of movement and by reclassifying the directional viewshed based on the proximity to the hillfort.

I Landserf uses quadratic approximation to calculate surface parameters. A quadratic trend surface is fitted to the data points corresponding to the centroids of the cells that lie within an $\mathrm{n} \times \mathrm{m}$ window. Surface parameters are calculated for the data point corresponding to the cell at the center of the $\mathrm{n} \times \mathrm{m}$ window. 
Two key themes emerge from the work on the hillforts of the Ridgeway: I) scale dependency, i.e., that the perception of topography and landscape and the influence of topography and landscape are dependent on scale; and 2) uncertainty, i.e., that considerable convergence and divergence occur between individual "solutions," so this is an exploratory process. Both of these themes are developed further in this paper using the concept of viewpaths.

\section{Case study: the Danebury long barrows}

Our study area is within the $450 \mathrm{~km}^{2}$ of chalk downland that has formed the focus for landscape studies around the Iron Age hillfort of Danebury, close to the Wiltshire/Hampshire border in southern Britain. The pioneering work of Palmer (I984) provided the base maps incorporating his extensive transcription and analysis of aerial photographs, subsequently digitized and used in an early GIS-based analysis of the development of this prehistoric landscape including Neolithic, Bronze Age and Iron Age monuments (Lock / Harris I996). Here we concentrate on a group of four long barrows in the north-western corner of the Danebury area (Fig. I), verified by fieldwork as follows:

- $\quad$ Barrow I3, Bulford I (Grinsell I957, I39)

- $\quad$ Barrow I4, Sheer Barrow (Crawford i958, LB77)

- $\quad$ Barrow I5, Milston 2 (Grinsell I957, I42)

- $\quad$ Barrow I7, Milston 39 (Grinsell I957, I42)

Long barrows are a distinctive class of Neolithic funerary monument, constructed during the mid- to late fourth millennium and early third millennium BC (Pouncett 2008). The visual characteristics of long barrows have provided a focus for GIS-based research, for example in order to explore territorial markers through the combination of binary viewsheds and Thiessen polygons (Lock / Harris I996), and modelling visibility to and from individual barrows by binary and cumulative viewsheds (Exon et al. 2000; Wheatley I995). Here we concentrate on integrating visibility with movement between individual barrows at various scales.

The dataset used here corresponds to an area $7 \mathrm{~km}$ by $7 \mathrm{~km}$ (centred on National Grid Reference SU I85 455) with the locations of the barrows extracted from Lock and Harris I996. The DTM (digital terrain model) is based on Ordnance Survey Landform Profile data with a Io $\mathrm{m}$ cell size and a vertical resolution of $0.0 \mathrm{I} \mathrm{m}$, obtained from Edina Digimap. A $5 \mathrm{~km}$ buffer has been applied to the dataset to minimize the impact of edge effects; this is more than double the mean distance to global horizon (see below) and assumes the maximum range of effective visibility. The DTM was re-sampled to a $25 \mathrm{~m}$ cell size to allow rapid calculation of total viewsheds (see below). The topography of the area ranges between $68 \mathrm{~m}$ and 20I $\mathrm{m}$ OD (Ordnance Datum = above mean sea level) although the long barrows are all at the lower end of the range and occur in a variety of landscape contexts: 


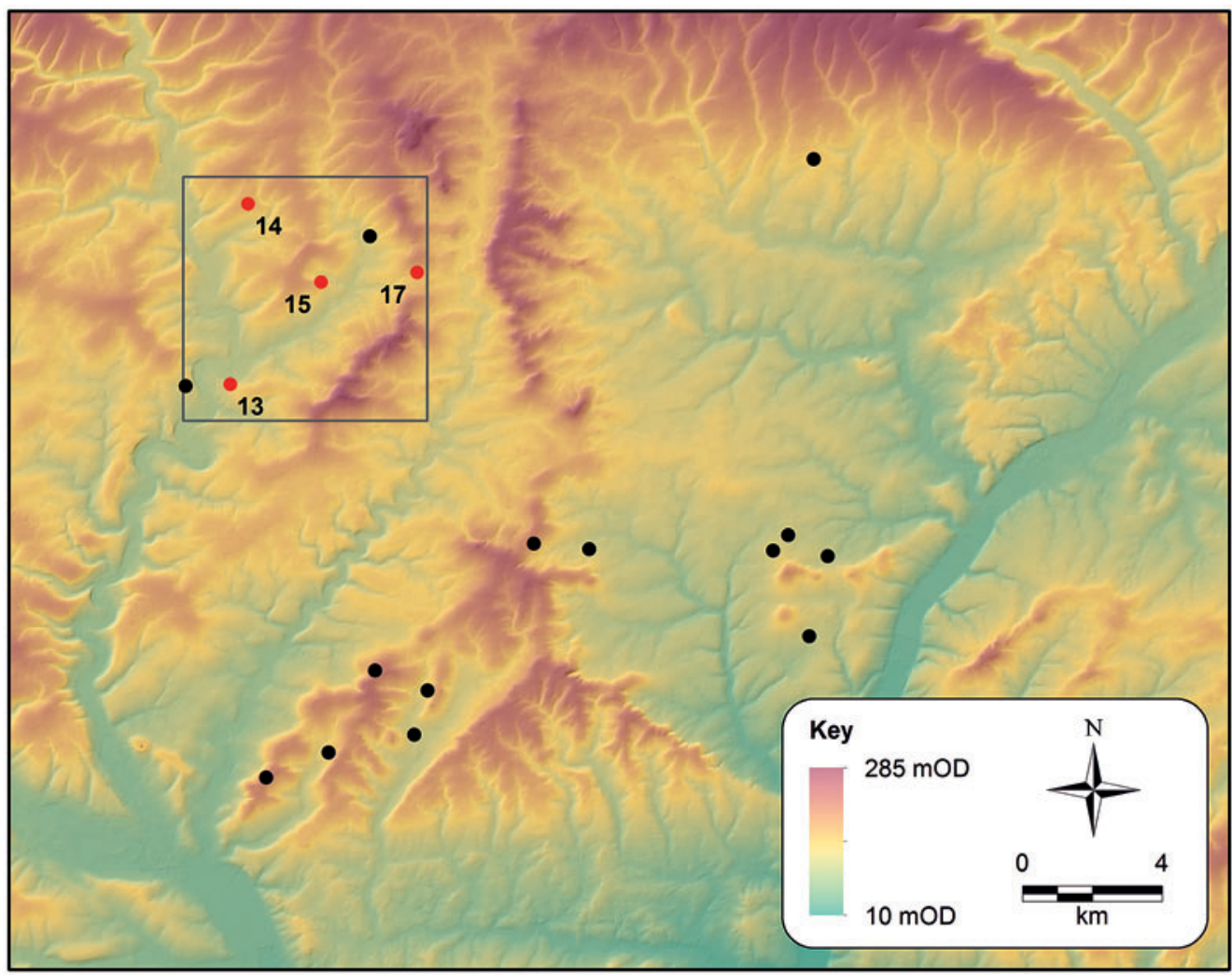

Fig. 1 | The Danebury area showing the study area used here and the location of long barrows. The barrows used for analysis in this paper are shown in red and numbered.

- $\quad$ Barrow I3 is situated on the lower slopes of a natural spur close to the apex of a tight bend in a river at a height of $96 \mathrm{~m} \mathrm{OD}$;

- $\quad$ Barrow I4 is located just below the crest of a natural spur overlooking the eastern bank of a river at a height of $\mathrm{I} 20 \mathrm{~m} \mathrm{OD}$;

- $\quad$ Barrow I5 is located on the upper reaches of a natural spur along the western edge of a river valley at a height of II2 $\mathrm{m}$ OD;

- $\quad$ Barrow I7 is situated on the northern edge of a pass between two river valleys at a height of $120 \mathrm{~m}$ OD.

By modelling movement between these barrows we are not suggesting that their use was contemporary or that people did, indeed, move between them. The emphasis of this paper is on developing a methodology, although the locations of the long barrows are variable enough to raise interesting questions about the possible choices to be made if moving between them: is movement favoured along river valleys or along the adjacent upland ridges, or both under different circumstances? 


\section{An integrated approach: moving and seeing}

An important attempt to integrate visibility characteristics within the process of modelling movement is Lee and Stucky's work on "viewpaths" (I998), in which a viewshed contributes to the friction surface used to generate a least cost pathway. This concept simulates the influence of visibility on movement and is developed further below. The viewpaths generated by Lee and Stucky were based on the calculation of two visibility surfaces or total viewsheds (viewgrids):

I. $\mathrm{V}_{\mathrm{G}}$ (General) - the number of cells which are visible from each cell ("looking out");

2. $V_{D}$ (Dominance) - the number of cells from which each cell is visible ("looking in"). These visibility surfaces or total viewsheds assume that the height of the observer and the height of the target are not equal, i.e., that the view "looking out" is different from the view "looking in" (see Fisher I996, fig. 2). Four different types of viewpath were calculated using friction surfaces based on different characteristics of $V_{G}$ and $V_{D}$ :

- Hidden Path - the path which is the least visible from other locations, with friction costs based on the lowest values of $\mathrm{V}_{\mathrm{D}}$;

- Scenic Path - the path with the highest visibility, with friction costs based on the inverted value of $\mathrm{V}_{\mathrm{G}}$;

- Strategic Path - the path with the least possibility of being visible from other locations but maintaining the highest visibility from the path itself, with friction costs based on the minimum of the value of $\mathrm{V}_{\mathrm{D}}$ or the inverted value of $\mathrm{V}_{\mathrm{G}}$;

- Withdrawn Path - the path that is both the least visible from other locations and has the lowest visibility, with friction costs based on the minimum of the values of $V_{D}$ or $\mathrm{V}_{\mathrm{G}}$.

Each of these four paths are tested against a benchmark Euclidean Path based solely on the horizontal distance and height difference between cells, so that comparisons of visibility, invisibility and efficiency (length of path) can be computed.

\subsection{Multi-scalar analysis}

The Hidden and Scenic viewpaths proposed by Lee and Stucky (I998) are also implemented here using a modified form of total viewshed where visibility is restricted to a specified scale of analysis or maximum visible distance (a technique elsewhere referred to as "fuzzy cumulative visibility analysis,", "FCVA", Kormann and Lock 20I4). By restricting the scale of analysis it is possible to model the range of visibility that influences movement as an agent makes his/her way through a landscape, in digital terms moving from cell to cell across a DTM. The locations which can be seen change as the agent moves from one cell to the next and the dynamic nature of this change is reflected in the values of the visibility indices for the resultant viewshed. 
Visibility indices are calculated for each cell in a DTM using a circular kernel with a radius equivalent to the maximum visible distance for the specified scale of analysis, so for example a $200 \mathrm{~m}$ scale of analysis is modelling a maximum distance of visibility of $200 \mathrm{~m}$ in any direction. The visibility indices are standardized by the maximum possible value of the visibility index for the specified scale of analysis in order to allow like-for-like comparison between different scales of analysis (Fig. 2). Values of the standardized visibility indices range between o (none of the cells in the kernel are visible) and I (all of the cells in the kernel are visible), indicating areas of lower and higher visibility. Two viewsheds were calculated for each scale of analysis, replicating the viewgrids which were used as friction surfaces for the viewpaths proposed by Lee and Stucky (above).

Rather than using arbitrary values for the scales of analysis, we here introduce the importance of skylines (or horizons) as a characteristic of visibility and, therefore, of movement. The importance of these, particularly with regard to astronomical alignments and territorial boundaries, has long been recognized in archaeology (Ruggles et al. I993). Conventional GIS-generated viewsheds fail to take into account the visual impact of landscape features relative to the position of skylines or horizons, i.e., points where the land touches the sky. Alternative forms of viewshed, including horizon viewsheds and local or global offset viewsheds, have been proposed to address this problem (Fisher I99I) although, because these are not standard push-button functions, they have not been widely adopted by archaeologists or other GIS practitioners. Here we use a variant of the horizon viewshed (Fisher I996) to determine the minimum and maximum scales of analysis used below, with the minimum scale defined as the mean distance to the local (closest) horizon and the maximum scale defined as the mean distance to the global (furthest) horizon (Fig. 3).

Euclidean Paths ( $c f$. Lee / Stucky I998 and above) were generated from Barrow I5 to each of the other long barrows in the study area (these are also used as the baseline below) using the Path Distance ${ }^{2}$ and Cost Path 3 tools in ArcGIS I0.0. These are based on slope distance, taking into account horizontal distance and height difference only, and were calculated using a constant friction surface (value $=\mathrm{I}$ ). Observer points were created at $100 \mathrm{~m}$ intervals along each of the Euclidean Paths for the purposes of calculating horizons. Lines of sight were generated for each of these observer points using $\mathrm{z}$ values equivalent to an observer height of $\mathrm{I} .60 \mathrm{~m}$ and a target height of $0.00 \mathrm{~m}$. An angular increment of $\mathrm{I}^{\circ}$ was used, resulting in 360 lines of sight per observer point $(36,720$ lines of sight in total). The resultant lines of sight were broken into visible and non-visible segments and the end points of the visible segments were defined as horizons. Distances to the horizons were aggregated

2 http://help.arcgis.com/en/arcgisdesktop/ıo.o/help/index.html\#/How_the_path_distance_tools_work/ 009z00000027000000/(seen 29. 06. 20II)

3 http://help.arcgis.com/en/arcgisdesktop/ıo.o/help/index.html\#/Creating_the_least_cost_path/ oogzo0000021000000/(seen 29. 06. 201I) 


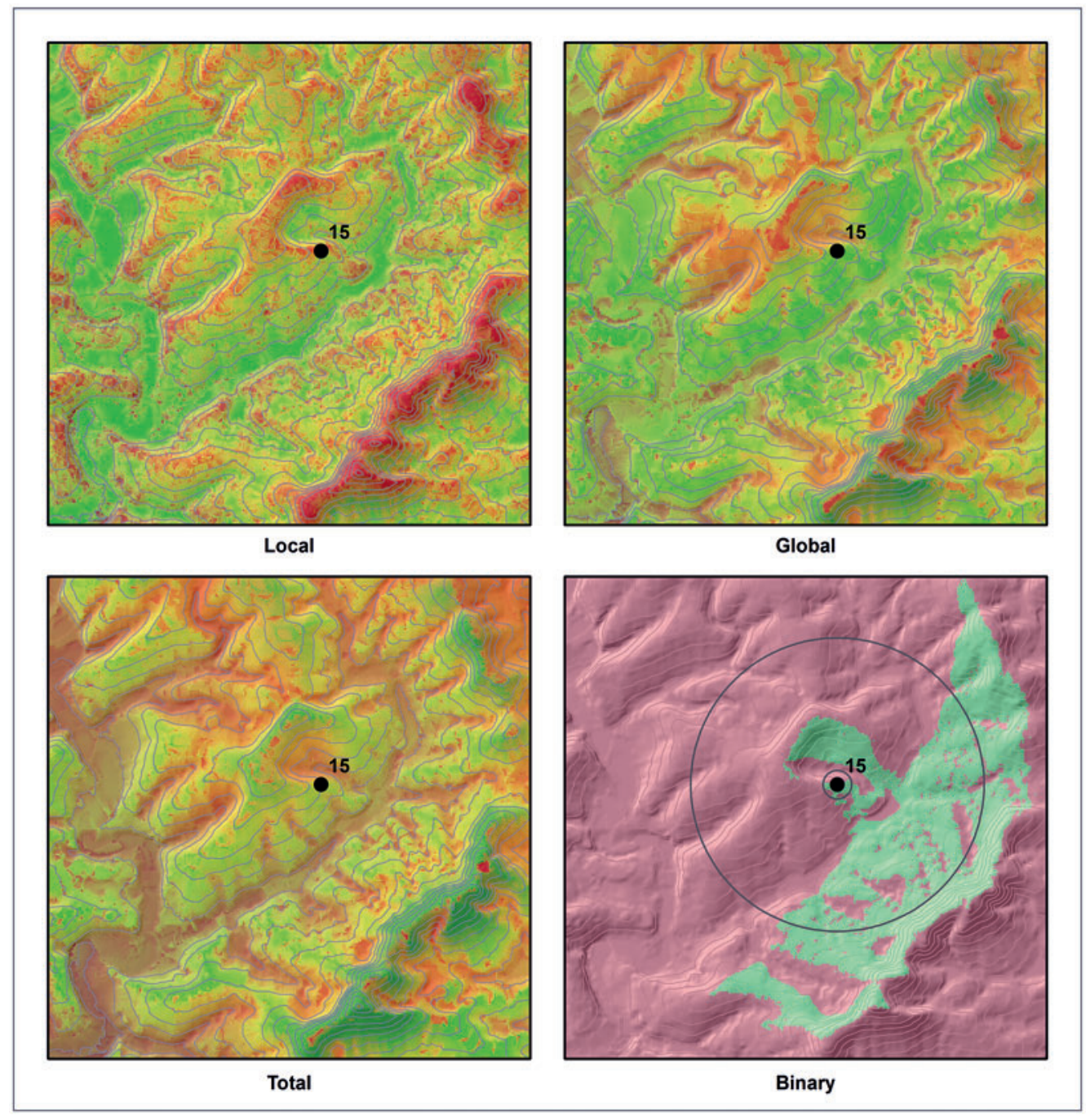

Fig. 2 Restricted viewsheds for the $7 \mathrm{~km}$ by $7 \mathrm{~km}$ study area (local $=200 \mathrm{~m}$, global $=2 \mathrm{~km}$ and total $=$ the whole area) compared against the binary viewshed for Barrow I5, red = o (low visibility / not visible), green $=\mathrm{I}$ (high visibility / visible), with north to the top. 


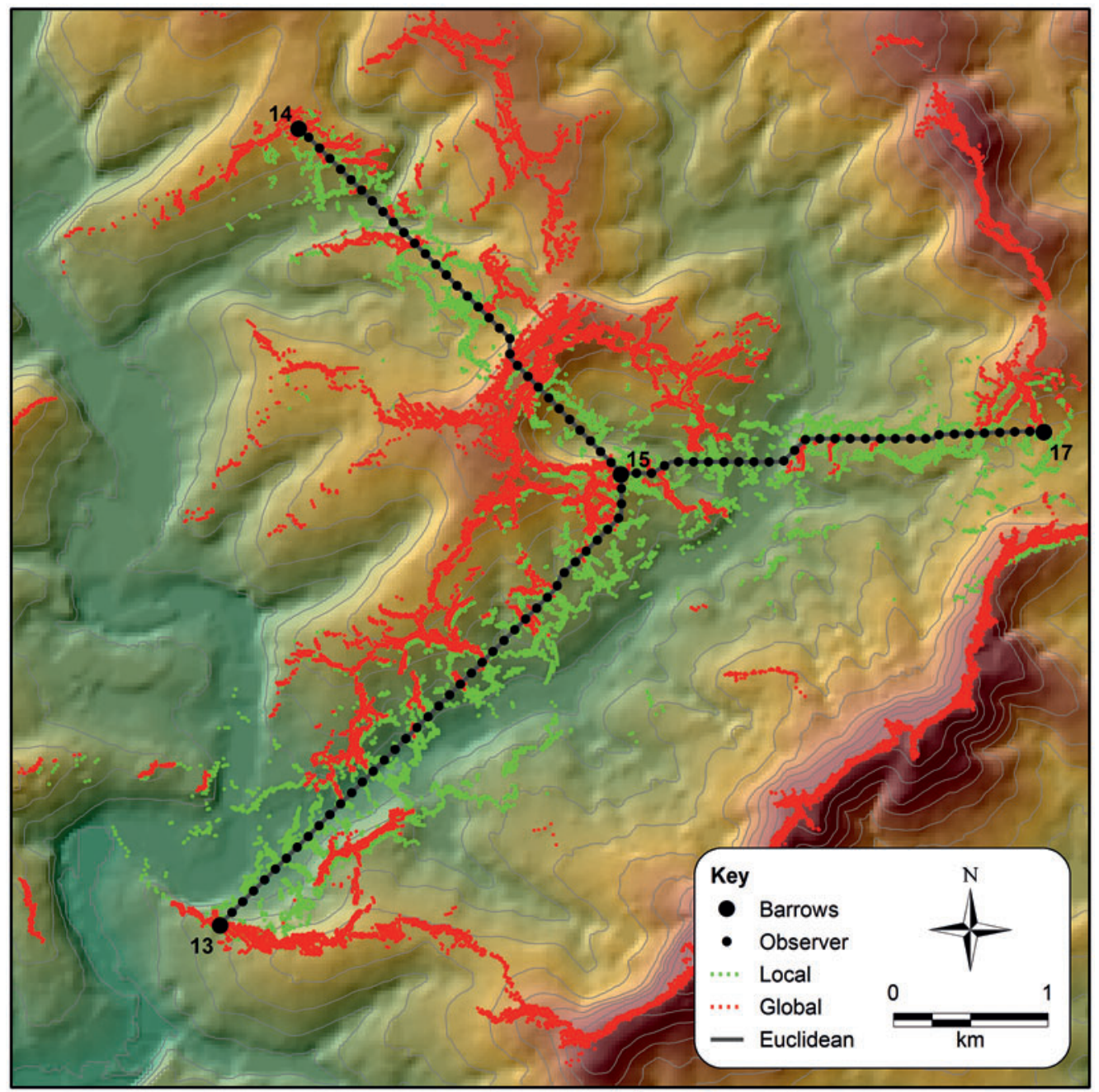

Fig. $3 \mid$ The Euclidean Paths between the barrows showing observer points at Ioo $\mathrm{m}$ intervals from which local horizons (green) and global horizons (red) were generated. 
for each observer point, calculating the minimum and maximum values, and these were averaged to calculate the mean distance to the local horizon 4 ( $207 \mathrm{~m}$, equivalent to 9 cells) and the mean distance to the global horizon 5 (2,130 m, equivalent to 79 cells). Although the actual values determined here are specific to the study area, the method (Pouncett 2013) by which they were established has wider applicability.

\subsection{Multiple paths}

Having established appropriate scales of analysis, initial viewpaths were generated using the visibility surfaces $\left(\mathrm{V}_{\mathrm{G}}\right.$ and $\left.\mathrm{V}_{\mathrm{D}}\right)$ proposed by Lee and Stucky (I998). Visibility surfaces were generated for viewpoints corresponding to the centroid of each cell in the DTM including the $5 \mathrm{~km}$ buffer $(462,400$ viewpoints in total) using the Viewshed tool in ArcGIS ro.0. ${ }^{6} V_{G}$ and $V_{D}$ viewgrids were obtained by inverting the observer (OFFSETA $V_{G}=$ I. $6 \mathrm{~m}$ and $V_{D}=0.0 \mathrm{~m}$ ) and target heights (OFFSETB $V_{G}=0.0 \mathrm{~m}$ and $\left.V_{D}=1.6 \mathrm{~m}\right)$. The maximum theoretical value for any cell in the total viewshed is 462,399 , since a cell cannot be visible from itself, although in practice values range between $\mathrm{I}_{7}$ and $67,5_{\mathrm{I}} 6$ for $\mathrm{V}_{\mathrm{G}}$ and 65 and 74,182 for $V_{D}$. This difference between the range of values for the two viewgrids highlights the significance of reciprocity (Conolly / Lake 2006, 229-230). Furthermore, in both instances the range of values is significantly lower than the maximum theoretical value, which suggests that the $5 \mathrm{~km}$ buffer has successfully eliminated any edge effects.

Perhaps unsurprisingly, the highest values in both the $V_{G}$ and $V_{D}$ viewgrids correspond to hilltops (peaks and ridges) and the lowest values correspond to valley bottoms (channels). The ridge running along the eastern edge of the study area, interrupted by the pass on which Barrow I7 is located, is the most highly visible topographic feature in the landscape. Whilst there are more areas of higher visibility for the $V_{G}$ viewgrid than for the $V_{D}$ viewgrid, they are also more fragmented, with localized areas of lower visibility along prominent hilltops. More pronounced differentiation can be seen between the $V_{G}$ and $V_{D}$ viewgrids at smaller scales of analysis; this is particularly noticeable at the local scale (more below). The $V_{G}$ and $V_{D}$ viewgrids were used to generate visibility-based friction surfaces for the purposes of calculating Hidden and Scenic Paths as defined above.

To provide a comparison between the various methods outlined here and generate a series of images that will serve to stimulate discussion, we compare the Euclidean, Hidden and Scenic Paths with a more conventional LCP (based on slope) generated using the for-

4 The end point of the first visible segment of a line of sight, also referred to as an intermediate horizon (Fisher I996).

5 The end point of the last visible segment of a line of sight, also referred to as a skyline (Fisher I996).

6 http://help.arcgis.com/en/arcgisdesktop/ıo.o/help/index.html\#/Performing_visibility_analysis_with_ Viewshed_and_Observer_Points/o09zoooooov8000000/(seen June 29. 06. 20II) 


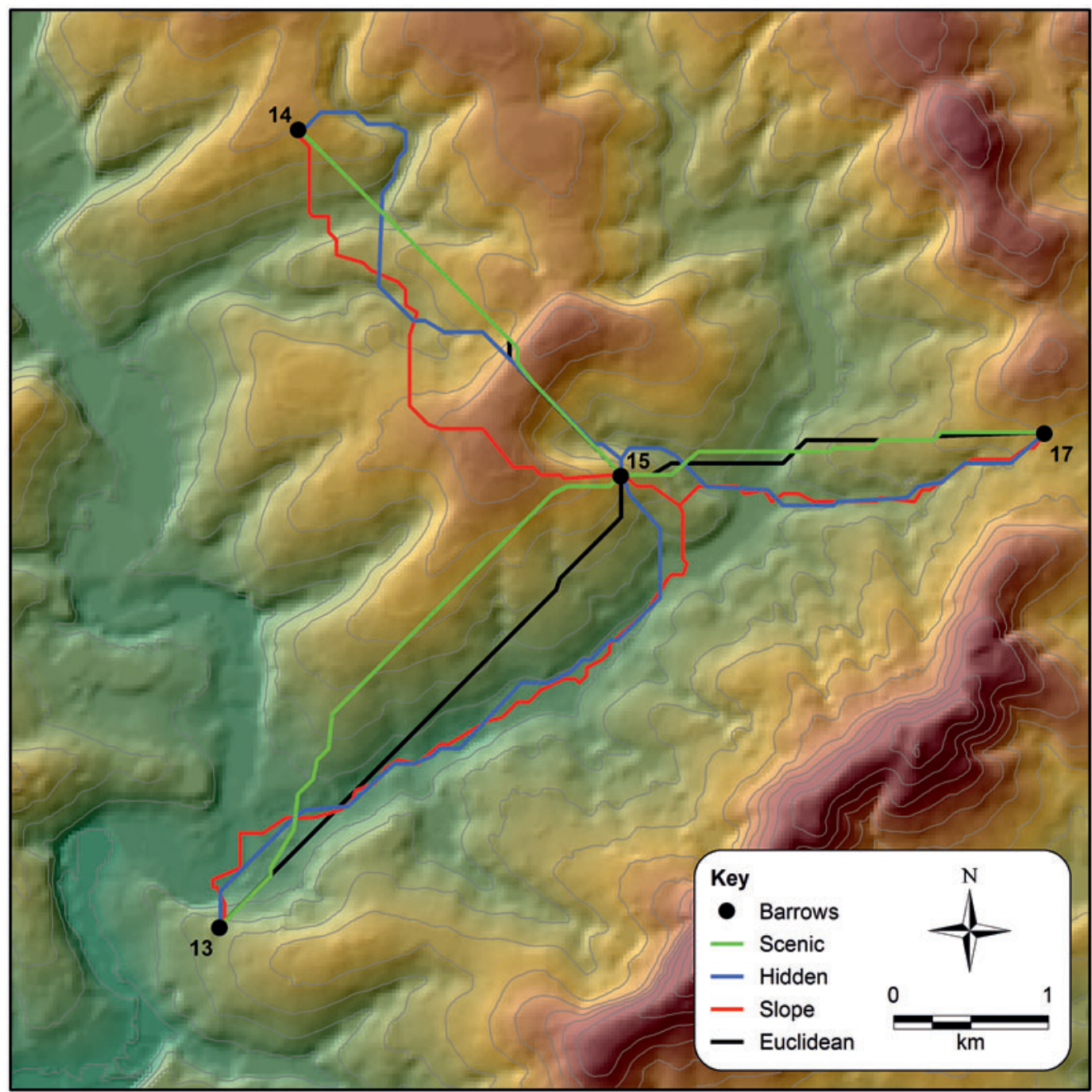

Fig. 4 | The Scenic and Hidden Paths between the barrows calculated using the total viewshed compared against the Slope and Euclidean Paths.

mula7 proposed by Bell and Lock (2000). Figure 4 illustrates the differences between these four paths from Barrow I5 to Barrows I3, I4 and I7, calculated using the total viewshed (as opposed to the restricted viewsheds based on the minimum and maximum scales of analysis, i.e., the mean distances to the local and global horizons respectively).

It can be seen that there is a strong correlation between the Scenic and Euclidean Paths from Barrow I5 to Barrows I4 and I7, whereas the viewpaths from Barrow I5 to Barrow I3

7 Cost $=\operatorname{Tan}\left(\operatorname{Slope}^{\circ}\right) / \operatorname{Tan}\left(\mathrm{I}^{\circ}\right)$ 
follow different routes, with the Scenic Path following the line of a ridge and the Euclidean Path cutting across the valley below. Likewise, there is a strong correlation between the Hidden and Slope Paths from Barrow I5 to Barrows I3 and I7, each following the line of a valley. In contrast the Hidden and Slope Paths from Barrow I5 to Barrow I4 follow different routes, one following the lines of ridges and cutting across valleys and the other following the lines of valleys and cutting across ridges. In both instances, the degree of correlation between the Scenic and Euclidean Paths and the Hidden and Slope Paths would appear to be dependent upon whether the initial direction of movement is upslope or downslope. Preference is given to higher ground in the case of the Scenic Paths to maintain a good view and to lower ground in the case of the Hidden Paths to stay out of view.

Although the Euclidean, Slope, Hidden and Scenic Paths all represent the same intent, i.e., to move from one barrow to another, Figure 4 shows that there are multiple possibilities for the same outcome based on different factors. The Euclidean Path minimizes the surface distance and is, therefore, the most "direct" route regardless of slope, whereas the Slope Path minimizes the relative cost, usually thought of as "effort," and so in effect is a longer but easier route. In contrast, the Scenic and Hidden Paths are influenced by visibility, the former maximizing "looking out," which can be considered as "the view" and the latter minimizing "looking in," so that by walking that route you are less likely to be seen. We are, of course, assuming here that people being seen is not important for Scenic Paths, but is so for Hidden Paths. Scale is inherent within these different paths and in the decisions made before and during walking them. For the Euclidean Path the scale can be considered "global," as it is based on knowing where the end point is and continuously minimizing the distance to it, whereas for the other three paths decision making is more "local," as it incorporates information based on slope or visibility at particular locations along the path. This can be regarded as the difference between analytical scale and phenomenological scale highlighted in the introduction, the latter attempting to be a digital representation of perception.

It is worth exploring scale a little further in terms of an agent located within a landscape and how that agent perceives the near and distant landscape characteristics and the opportunities for movement. Previous work on the hillforts of the Ridgeway (Lock / Pouncett 2010) has highlighted the importance of scale-dependency and how the value of slope is linked to the distance over which it is calculated, so that different values will be obtained by assessing the terrain closer to, or further away from, the observer. Since the friction costs used to calculate the Slope Path are based on those values, visibility and movement are intrinsically linked. It has long been recognized that visibility is scale-dependent and here we expand on that insight through the use of two different scales of analysis. The paths shown in Figure 4 are based on the total viewshed, i.e., unrestricted vision across the whole area. In Figures 5 and 6 the Hidden and Scenic Paths are shown using the restricted viewsheds for scales of analysis based on the mean distances to the local and global horizons, i.e., maximum visible distances of circa $200 \mathrm{~m}$ and circa $2 \mathrm{~km}$ respectively. These paths are referred to accordingly as Total, Local and Global Paths in the text below. 


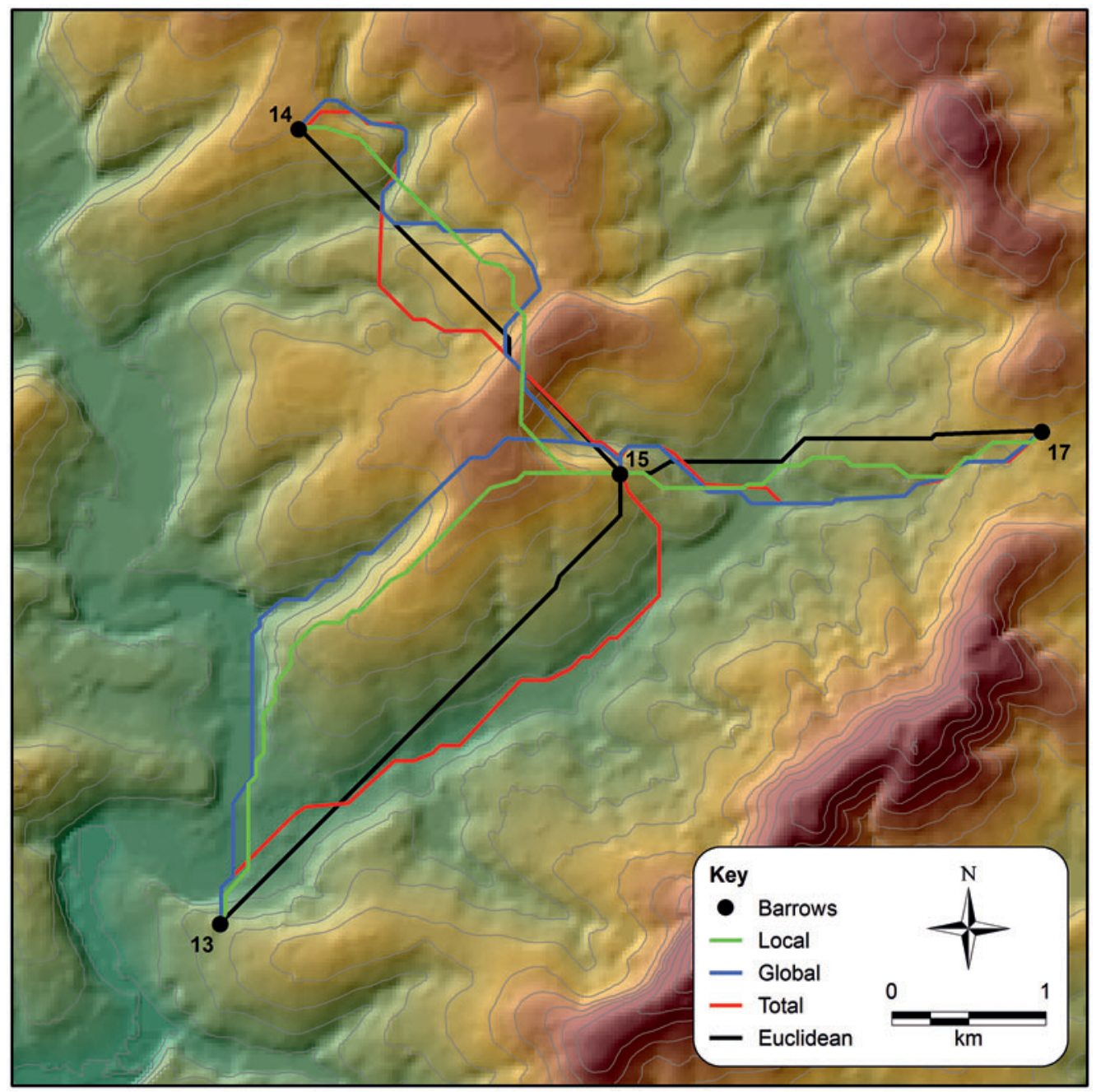

Fig. 5 | The Hidden Paths between the barrows calculated using the restricted viewsheds (local = $200 \mathrm{~m}$ and global $=2 \mathrm{~km}$ ) and the total viewshed compared against the Euclidean Paths.

Looking in detail at the Hidden Paths first (Fig. 5), we can see for the route from Barrow I5 to Barrow I7 a close correlation between all paths except the Euclidean Path, with each path following the line of the same valley. The Global and Total Paths are almost identical, consistent with the "restricted" view from the valley bottom, whereas the Local Path hugs the base of the slope along the northern side of the valley rather than following the valley bottom. All of these routes offer less opportunity for being seen when compared to the alternative route along the ridge-top taken by the Euclidean Path. Greater variation can be seen between the routes from Barrow I5 to Barrows I3 and I4, most evident in the case of the 


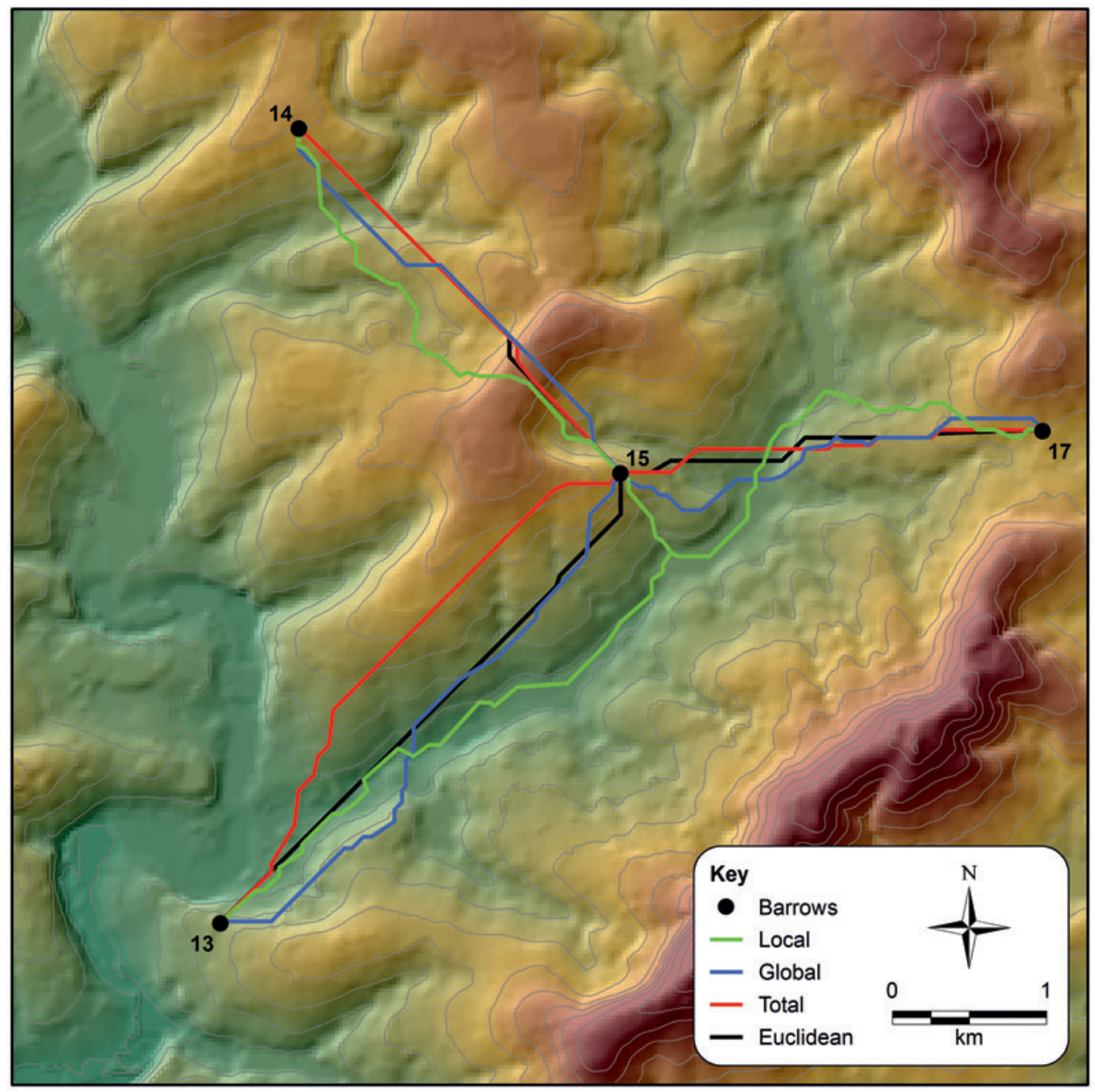

Fig. 6 The Scenic Paths between the barrows calculated using the restricted viewsheds (local=200 $\mathrm{m}$ and global $=2 \mathrm{~km}$ ) and the total viewshed compared against the Euclidean Paths.

Total Path from Barrow I5 to Barrow I3, which follows the line of the valley to the south of Barrow I5. This is in sharp contrast to the Global and Local Paths from Barrow I5 to Barrow I3: the Global Path skirts the northern edge of the spur on which Barrow I5 is located, cutting directly across the top of the adjoining ridge, before following the line of a valley to the west of Barrow I5 to reach Barrow I3, while the Local Path follows a similar route but with subtle differences, skirting the northern edge of the spur before hugging the northeastern edge of the adjoining ridge. The Global and Local Paths use more immediate topographic features to provide cover from closer view, whereas the Total Path is concerned with 
being seen from further away. Similar subtleties of difference can be seen between the routes from Barrow I5 to Barrow I4 at different scales of analysis.

Perhaps not surprisingly the Scenic Paths, i.e., those maximizing looking out, produce equally rich opportunities for interpretation (Fig. 6). There is a good correlation between the Scenic Paths from Barrow I5 to Barrow I4, with all of the paths following a similar line along or across the same topographic features. Greater variation can be seen between the paths from Barrow I5 to Barrows I3 and I7. Again, the greatest discrepancies are with the paths from Barrow I5 to Barrow I3 where, although the Global Path corresponds closely to the Euclidean Path, the paths for restricted scales follow different topographic features. The Total Path follows the line of the ridge to the southwest of Barrow I5, while the Local Path follows the line of the valley below. Interestingly the Scenic Local Path and Total Hidden Path have very similar routes along the valley bottom, perhaps indicating that even for the latter the immediate topography is of most importance in restricting "looking in." It is also interesting that the Local Paths for the routes between all barrows deviate the most from the Euclidean Paths - an important point as it shows the influence of localized topographic features which are taken into account by the observer when moving.

\section{Discussion}

The analysis described above has shown that there is no single path between two locations and multiple possibilities exist depending on the intentions of the agent: to generate a single least cost pathway and claim significance for it as an "exact" route is a naïve and reductionist attempt at modelling movement, especially when the influence of visibility is taken into account. This is clear in Figures 4 and 5, which show a marked variation in the degree of correlation between the Hidden and Scenic Paths from Barrow I5 to Barrows I3, I4 and I7. In this section we present some initial work that attempts to move beyond single paths and explores the idea of corridors of intentionality through probability surfaces, which show the differing affordance of movement and visibility across the landscape.

In areas where there is a strong correlation between different paths (for example, Fig. 6, the Scenic Paths from Barrow I5 to Barrow I4), there is greater confidence that an individual cell will lie on the line of a particular path. Conversely, in areas where there is a poor correlation between different paths (for example, in Fig. 6, the Scenic Paths from Barrow I5 to Barrow I3) there is lower confidence that an individual cell will lie on the line of a particular path. Also important here is the notion of reciprocity, which is explicitly acknowledged by the distinction between the $V_{G}$ and $V_{D}$ viewgrids used as friction surfaces for the Hidden and Scenic Paths (see above). Depending upon the values of the observer and target heights used (here $\mathrm{I} .60 \mathrm{~m}$ and $0.00 \mathrm{~m}$ ), it cannot be assumed that Point A can be seen from Point B simply because Point B can be seen from Point A. Similarly, depending upon 
whether an isotropic or anisotropic cost surface is used, it cannot be assumed that the least cost pathway between Points A and B will be the same as that between Points B and A.

In the case of the Slope Paths, one possible solution would be to calculate a least cost corridor between each pair of long barrows rather than two separate least cost pathways. Least cost corridors can be calculated by adding the individual cost surfaces for two points together so that each cell in the grid has a value which represents the lowest combined accumulated cost to get to both points. In the case of an isotropic cost surface, the least cost pathway will correspond to the cells within the least cost corridor with the lowest values and as such, the cell values can be inverted and standardized with values ranging between $o$ and I to reflect the probability that a cell lies on a least cost pathway.

Here we extend the notion of a least cost corridor to generate probability surfaces that show the areas in which a least cost pathway or viewpath is most likely to exist. Least cost corridors were generated for the Scenic Paths from Barrow I5 to Barrows I3, I4 and I7 using the Corridor tool in ArcGIS I0.0. ${ }^{8}$ To construct the image shown in Figure 7 , three least cost corridors were calculated for each pair of long barrows, one for each scale of analysis (local, global and total), and converted to probability surfaces by inverting and standardizing the raster datasets for each of the least cost corridors so that the values of the cells ranged between I and 0.9 The individual probability surfaces were clipped to show cells with values $=0.95$ (i.e., cells with a $95 \%$ or higher confidence level) and overlain using the Cell Statistics tool in ArcGIS IO. IO $^{\text {to }}$ create a single surface showing the maximum probability values for the Scenic Paths for the three combined scales of analysis (contrast Fig. 7 and 6).

Marked variation can be seen in the resultant probability surface, with differential spatial patterning in the probability values along the line of individual paths. Several key points arise: all of the cells corresponding to the lines of Scenic Paths fall within the range of the clipped values for the probability surface, although probability values vary; the areas of highest probability for the paths from Barrow I5 to Barrow I4, where the Scenic Paths are strongly correlated, are more extensive than those for the paths from Barrow I5 to Barrows I3 and I7, where the scenic paths are poorly correlated; the areas where the greatest difference between the paths for different scales of analysis or initial points of divergence occur correspond to cells which fall at the lower end of the range of probability values.

It is clear from this example that the probability surface provides a much richer and more sophisticated understanding of the likely paths between the barrows than the individual

8 http://help.arcgis.com/en/arcgisdesktop/Io.০/help/index.html\#/Creating_a_least_cost_corridor/ $009 z 00000024000000 /$ (seen 29. 06. 20II)

9 Cells with a value close to I are more likely to lie within the least cost corridor for each pair of long barrows (i.e., cells which have a high probability of lying on a path between the long barrows). Conversely, cells with a value close to $o$ are less likely to lie within the least cost corridor for each pair of long barrows (i.e., cells which have a low probability of lying on a path between the long barrows).

Io http://help.arcgis.com/en/arcgisdesktop/ı0.o/help/index.html\#/How_Cell_Statistics_works/ 009z00000088000000/(seen I8. 10. 20II) 


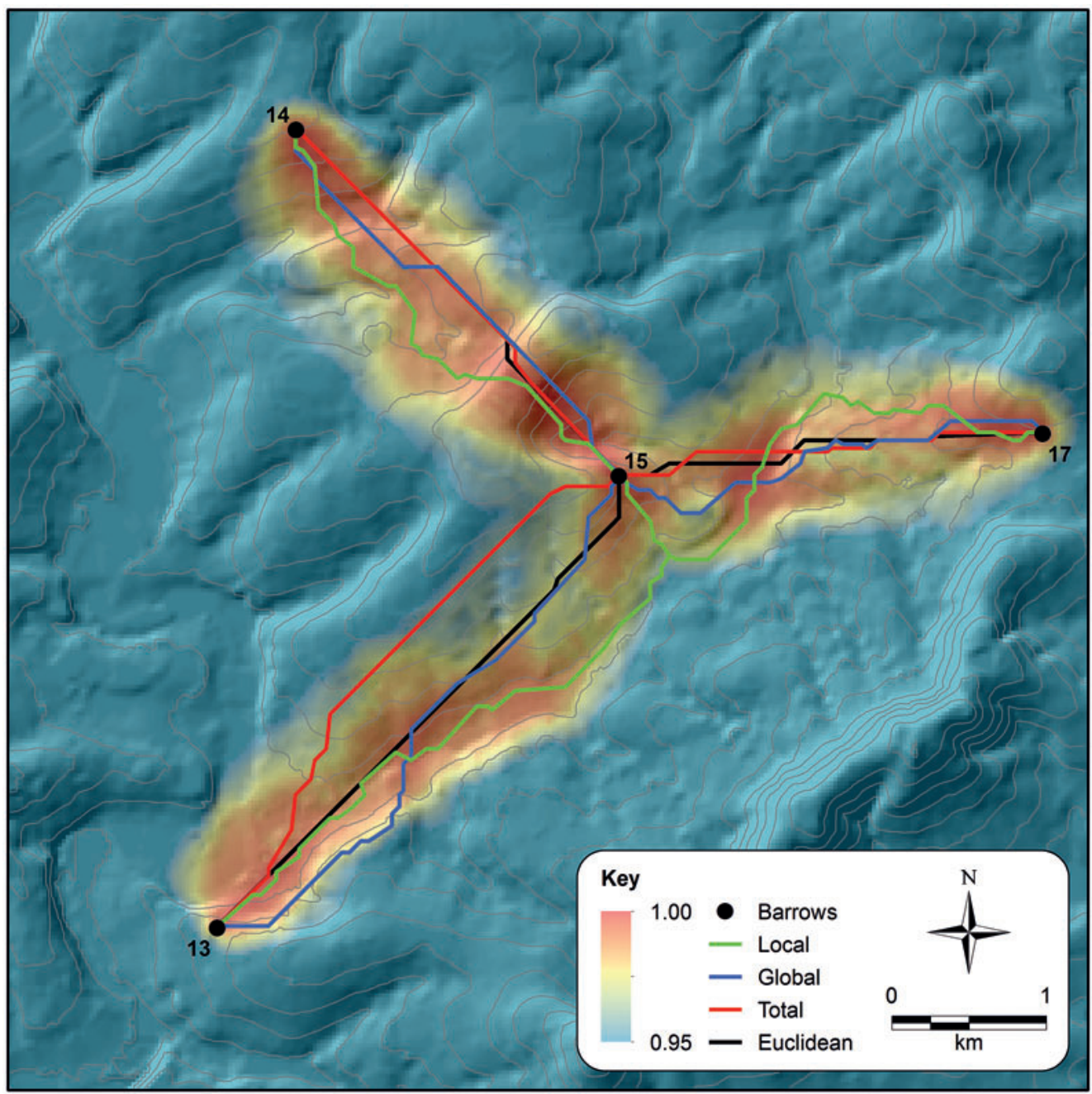

Fig. $7 \mid$ The probability surface for Scenic Paths at different scales, blue = low probability (lowest values equivalent to $<=95 \%$ ), red $=$ high probability (I00\%), with values clipped to show those of interest.

least cost pathways or viewpaths. By looking at the correlation between the probability values and the underlying topography it is possible to explore the reasons for the convergence and divergence of paths between two locations at different scales of analysis. In terms of movement, visibility and perception of the landscape, this is an attempt to model the complex choice of direction on offer as an agent proceeds along a pathway to an intended destination. The choice will involve what can be seen in the immediate vicinity, in the middle distance and in the far distance, as well as the perceived topography and the affordance for movement offered at those different distance ranges, together with the known direction of the destination. 
The methods of analysis which underpin the integrated approach to modelling movement and visibility advocated in this paper both compliment and extend existing approaches to modelling movement or visibility. Probability surfaces, for example, are a more transparent representation of the results of modelling movement than least cost pathways, showing the areas through which a path is most likely to pass rather than a single solution which may or may not correspond to an actual path. Similarly, scale-sensitive methods emphasize the importance of perception with regard to modelling visibility, which highlights the need to perform analysis at a scale which is appropriate to a particular landscape rather than at a scale which is entirely arbitrary. The analysis of the Danebury long barrows presented above has demonstrated the interpretative potential of these methods, which integrate movement and visibility in order to model human behaviour in a more realistic manner and using the mean values of the distances to the local and global horizons to model that behaviour at a "phenomenological" rather than an "analytical" scale.

\section{References}

Bell, T. / Lock, G. (2000)

"Topographic and Cultural Influences on Walking the Ridgeway in Later Prehistoric Times", in: G. Lock (ed.), Beyond the Map: Archaeology and Spatial Technologies, Amsterdam, $85-100$.

Crawford, O. (1958)

Neolithic Wessex: Showing the Distribution of Long Barrows, Circles, Habitation Sites, Flint Mines, Southampton.

Conolly, J. / Lake, M. (2006)

Geographical Information Systems and Archaeology, Cambridge.

Dobres, M.-A. (2000)

Technology and Social Agency, Oxford.

Exon, S. / Gaffney, V. / Woodward, A. / Yorston, R., (2000)

Stonehenge Landscapes: Journeys through Real and Imagined Landscapes, Oxford.

Fisher, P. (1991)

"First Experiments in Viewshed Uncertainty: The Accuracy of the Viewshed Area", in: Photogrammetric Engineering and Remote Sensing 57(IO), I32I-I327.

Fisher, P. (1996)

"Extending the Applicability of Viewsheds in Landscape Planning", in: Photogrammetric Engineering and Remote Sensing 62(II), I297-1302.

Gaffney, V. / van Leusen, M. (1995)

"GIS, Environmental Determinism and Archaeology", in: G. Lock / Z. Stančič (eds.) Archaeology and Geographic Information Systems: A European Perspective, London, 367-382. 
Gibson, J. (1979)

The Ecological Approach to Visual Perception, Boston.

Green, S. (1990)

"Approaching Archaeological Space: An Introduction to the Volume”, in: K. Allen / S. Green /

E. Zubrow (eds.), Interpreting Space: GIS and Archaeology, London, 3-8.

Grinsell, L. (1957)

"Archaeological Gazetteer Including a List of Wiltshire Barrows, Circles and Enclosure of 'Highworth' Type, Ditches, Enclosures and Hill-forts, and Field Systems”, in: R. Pugh /

E. Crittall (eds.), A History of Wiltshire. Volume I, Part I, Oxford.

Ingold, T. (2000)

The Perception of the Environment: Essays on Livelihood, Dwelling and Skill, London.

Ingold, T. (20II)

Being Alive. Essays on Movement, Knowledge and Description, London.

Kormann, M. and Lock, G. (2014)

"Exploring Differences: Implications for FCVA Visibility Indices and Scales of Analyses", in: Kamermans, H. / Godja, M. / Posluschny, A. (eds.), A Sense of the Past. Studies in Current Archaeological Applications of Remote Sensing and Non-invasive Prospection Methods. Oxford: BAR International Series 2588, I47-I54.

Lee, J. / Stucky, D. (1998)

"On Applying Viewshed Analysis for Determining Least-cost Paths on Digital Elevation Models", in: International Journal of Geographic Information Science I2(8), 89I-905.

Llobera, M. (2000)

"Understanding Movement: A Pilot Model towards the Sociology of Movement", in: G. Lock (ed.), Beyond the Map: Archaeology and Spatial Technologies. Amsterdam, 65-84.

Lock, G. / Harris, T. (1996)

"Danebury Revisited: An English Iron Age Hillfort in a Digital Landscape", in: M. Aldenderfer / H. Maschner (eds.), Anthropology, Space, and Geographic Information Systems, New York, 2I4-240.

Lock, G. / Molyneaux, B. (eds.) (2006)

Confronting Scale in Archaeology: Issues of Theory and Practice, New York.

Lock, G. / Pouncett, J. (2010)

"Walking the Ridgeway Revisited: The Methodological and Theoretical Implications of Scale Dependency for the Derivation of Slope and the Calculation of Least-cost Pathways", in: B. Frischer / J. Webb Crawford / D. Koller (eds.), CAA 2009 Making History Interactive. Proceedings of the 37th CAA Conference, Williamsburg, Virginia, USA, Oxford, I9I-202.

Lock, G. / Pouncett, J. (forthcoming)

"Spatial Thinking in Archaeology: Is GIS the Answer?", in E. Deweirdt / J. Bourgeois (eds.), Spatial Analysis Applied to Archaeological Sites from Protohistory to the Roman Period, Ghent. 
Madry, S. / Crumley, C. (1990)

"An Application of Remote Sensing and GIS in a Regional Archaeological Settlement Pattern Analysis: The Arroux River Valley, Burgundy, France”, in: K. Allen / S. Green / E. Zubrow (eds.), Interpreting Space: GIS and Archaeology, London, 364-380.

Palmer, R. (1984)

Danebury. An Iron Age Hillfort in Hampshire. An Aerial Photographic Interpretation of its Environs, London.

Pouncett, J. (2008)

"The Neolithic Period", in: R. Adkins / L. Adkins / V. Leitch (eds.), The Handbook of British Archaeology, London, 36-62.

Pouncett, J. (2013)

"Expanding Horizons: Visibility, Monuments and Topography". Paper Given at the 41st Computer Applications and Quantitative Methods in Archaeology Conference (CAA 2013 Perth), 25th to 28th March 2013, Perth, Western Australia.

Ruggles, C. / Medyckyj-Scott, D. / Gruffyd, A. (1993)

"Multiple Viewshed Analysis Using GIS and its Archaeological Application: A Case Study in Northern Mull", in: J. Anderson / T. Madsen / I. Scollar (eds.), Computer Applications and Quantitative Methods in Archaeology, CAA 92, Aarhus, I25-132.

Wheatley, D. (1993)

"Going over Old Ground: GIS, Archaeological Theory and the Act of Perception", in: T. Madsen / I. Scollar (eds.), Computing the Past: Computer Applications and Quantitative Methods in Archaeology CAA92, Aarhus, I33-I38.

Wheatley, D. (1995)

"Cumulative Viewshed Analysis: A GIS-based Method for Investigating Intervisibility, and its Archaeological Application”, in: G. Lock / Z. Stančič (eds.), Archaeology and Geographic Information Systems: A European Perspective, London, I7I-I86.

Wheatley, D. / Gillings, M. (2000)

"Vision, Perception and GIS: Developing Enriched Approaches to the Study of Archaeological Visibility", in: G. Lock (ed.), Beyond the Map: Archaeology and Spatial Technologies, Amsterdam, I-27.

Wood, J. (1996)

"The Geomorphological Characterisation of Digital Elevation Models", Unpublished Ph.D. thesis, University of Leicester. 
Élise Fovet*, Klemen Zakšek ***

\section{Path Network Modelling and Network of Aggregated settlements: a case study in Languedoc (Southeastern France)}

\section{Introduction}

The possibilities and constraints on the movement of people and goods is a key factor that determines practices and structures space. The evolution of the communication network is therefore very important for understanding the evolution of a region. Our study aims to analyse the changes in the pattern of ancient aggregated settlements through communication network modelling. The reconstruction of the ancient communication network is a means of understanding the evolution of this pattern not as a succession of creations and abandonments of settlements - point maps - but as a changing network.

The study area is located in Languedoc (southeastern France) and extends from the Mediterranean coast to the hills of the hinterland (Fig. I). In coastal regions, the communication network is traditionally associated with sea and river freight. However, this paper deals with the road network at the regional scale, not with trade at Mediterranean level. In addition, it should be noted that the extent of navigability on local rivers in the periods under study is open to question; for example, the most important river of the study area the Vidourle river - was navigable only during high water before its embankment from the plain from the Middle Ages onwards. The road networks have therefore played a major role in trade at the regional level in this area.

Thanks to numerous previous studies, we have a good overview of the ancient settlement distribution and dynamic in most of the study area (Favory et al. 1985; Favory et al. I994a; Durand-Dastes et al. I998; Nuninger 2002). However, knowledge of the ancient road network in this region is still deficient (Fig. 2). Research has long focused on the axis of long-distance communication connecting Italy to Spain through southern Gaul, known as the Via Domitia (from the Rhone to the Pyrenees), also called the "Heraclean road" in the context of the prehistoric periods. In the study area, its itinerary is reported by ancient sources (literary and epigraphic) and most of its course has been reconstructed from its milestones (Castellvi et al. I997). However, inter-regional roads - the "medium" level of the communication network - are still poorly known. Following G. Charvet, it is generally considered that the major communication routes - linking Nîmes to other capital cities - fol-

\footnotetext{
* MSHE Ledoux (USR 3I24), Laboratory of Chrono-Environnement (UMR 6249), ModeLTER, Besançon, France. ** University of Hamburg, Institute of Geophysics, Hamburg, Germany / Centre Of Excellence Space-Si, ModeLTER, Ljubljana, Slovenia.
} 


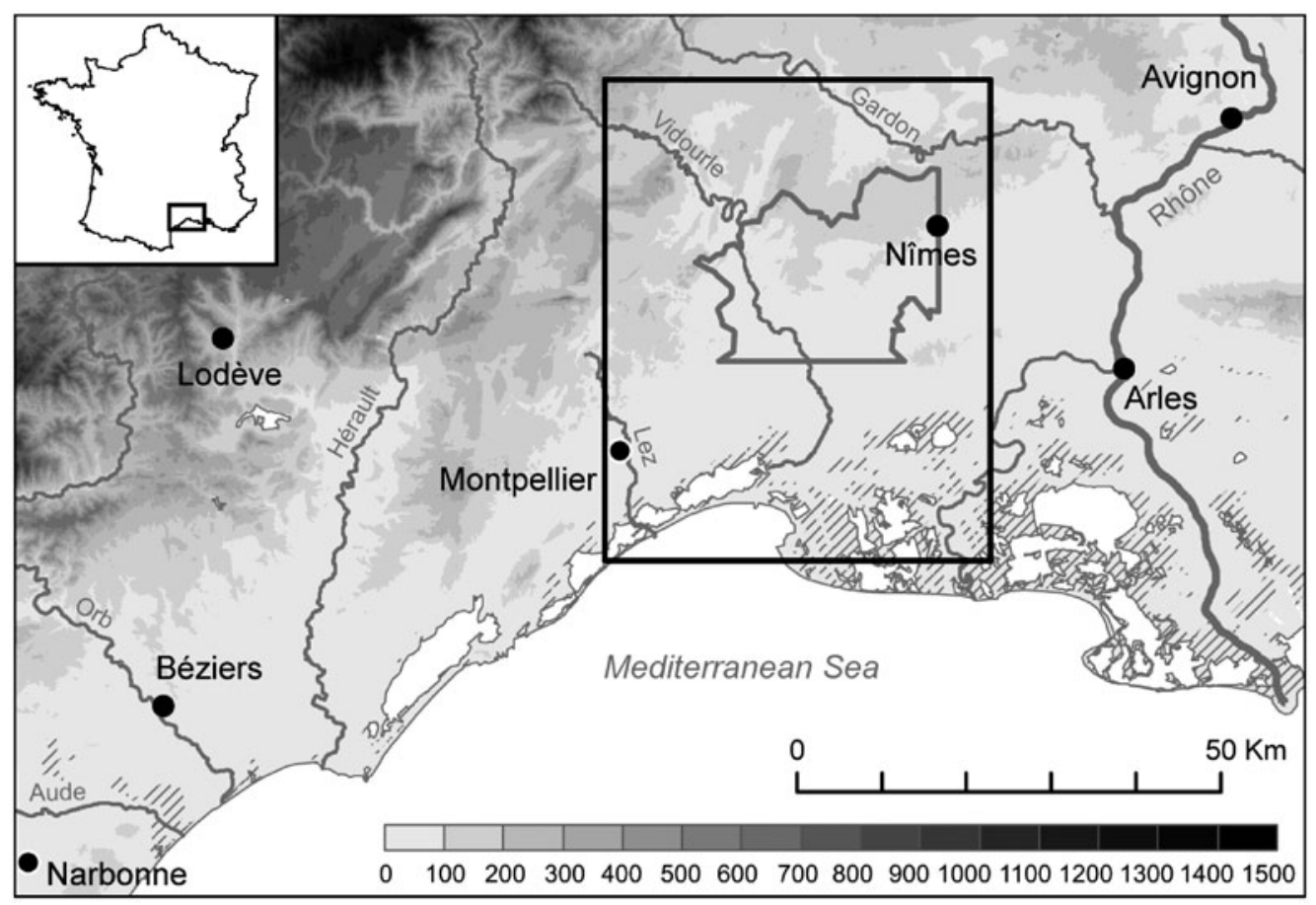

Fig. 1 Study area and subset for settlement pattern analysis.

low approximately the course of present-day roads (Charvet I873; Clément 2003; Monteil I999; Provost et al. I999; Fiches 2002, 2I, fig. 4). It is also assumed that transhumance paths and medieval salt and pilgrimage roads were used from Roman or prehistoric times (Clément 2003; Favory et al. I985; Favory et al. 1994b; Fiches 2002, 80-8I). At the same time, in some areas, map and photointerpretation studies carried out at local scale propose numerous possible Roman paths (Parodi et al. I987; Bonnaud / Raynaud I994; Raynaud 2002), since the communication network seems to be well preserved in the landscape of this region: the archaeological sites are indeed often close to present paths. It is nevertheless very difficult to define the status of these hypothetical segments of ancient roads in the ancient communication network: were they part of the regional network or local paths between farms?

These reconstructions of ancient routes are based on regressive methodology, ${ }^{\mathrm{I}}$ which starts from present-day elements of the landscape and selects tracks identified as being re-

I This kind of methodology uses the position of places of interest (river crossings, settlements), landscape analysis and toponymy. It results in the assembly of various segments of linear elements in the present landscape, interpreted as remnants of old routes. 
lated to the periods under study. However, there is very little evidence to date the use of these old roads. Moreover, studies on roads have shown that the routes change, mainly because of attraction by later settlements, and may undergo minor or major course changes (Vion i989). Roads have a history and their course results from a long and complex evolution that combines abandonments, changes in status and reactivations (Vion I989, 89). That is the reason why the number of proposed routes for a given regional road increases in areas where precise studies have been carried out (see box in Fig. 2).

The knowledge yielded by a regressive approach is too scant to handle ancient road networks: the chronology and status of known roads are uncertain and many major connections remain to be located. Therefore, we adopted a constructive approach. Optimal path modelling, that is, simulating the connections between contemporary archaeological sites, helps to apprehend the whole communication network in its relative chronology and hierarchy.

In contrast to the methods that have previously been used to study the road network in Languedoc, the aim of modelling is not to find the ancient roads in a precise manner, but to locate the communication channels that potentially result from the distribution of settlements. Optimal path modelling helps determine the most plausible path between two places, taking into account factors affecting mobility. In a further step, the computation of optimal paths between a set of places - optimal path network modelling - gives the structure of a network; the multiplication of modelled paths highlights the communication channels which, according to the factors considered, are the most likely: that is, development in the form of roads is most likely where the intensity of trade is potentially highest.

Our goal was not to study the numerous paths, built or not, that connect all settlements, but rather to trace the main communication channels that cross the region. This scale of analysis restricted the study to a specific level of the network and guided the choice of sites for path modelling. The regional level of the communication network has been modelled from the distribution of the agglomerations. Our selection of the major sites is based upon the collective research programme "L'habitat groupé gallo-romain et les agglomérations secondaires en Languedoc-Roussillon" (Fiches 2002). These sites can be very large or quite small ( 2 ha or less), nevertheless they all present evidence of specific status, such as the organizational structure of buildings, the presence of religious activity, epigraphy, etc. It is acknowledged that agglomerations played an important role in the spatial organization of the territory of Nîmes between the capital city and rural settlements (Fiches 2002, I5). So occasionally we will call these sites "centres," referring to centres of gravity of the economy or population. 


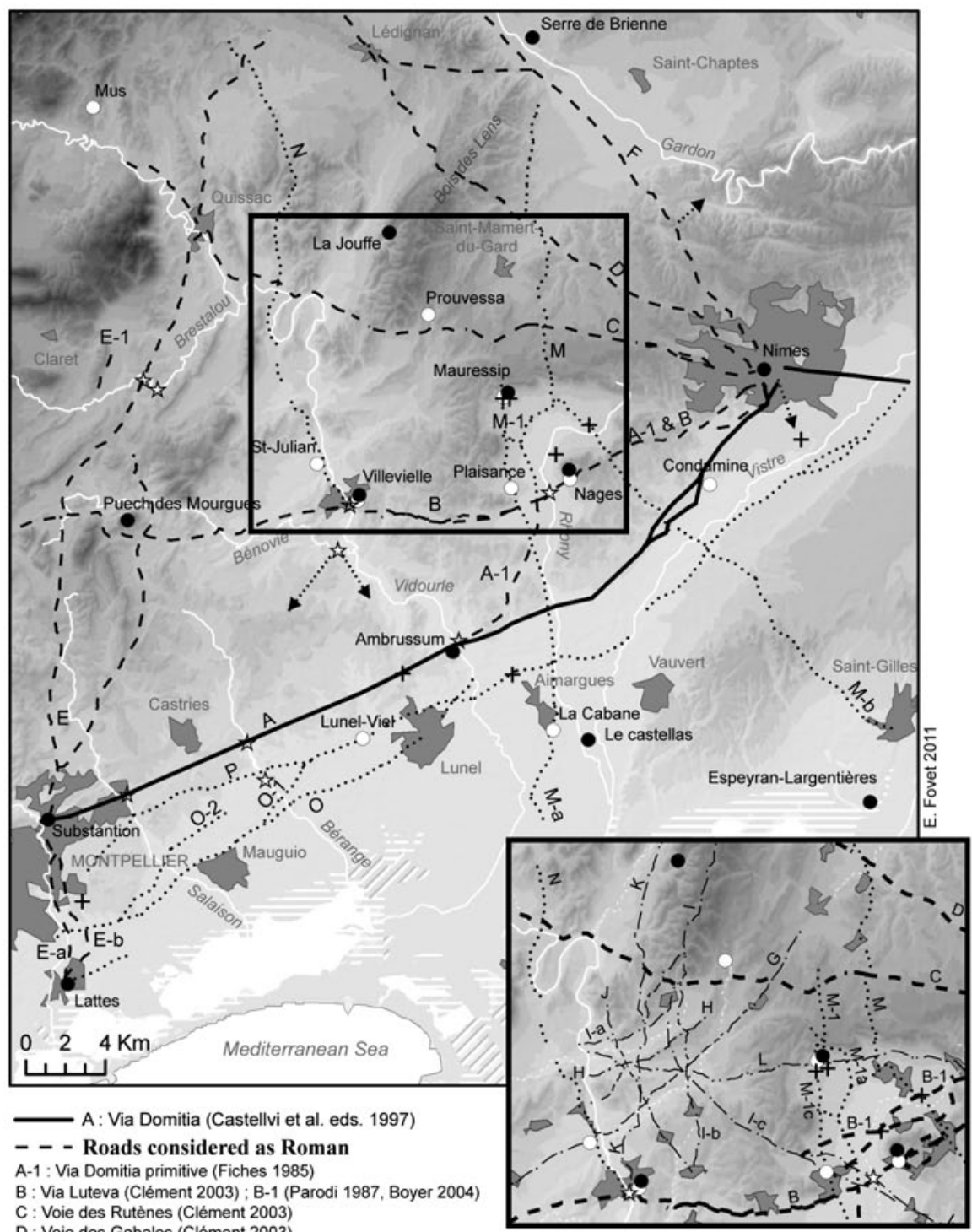

B : Via Luteva (Clément 2003) ; B-1 (Parodi 1987, Boyer 2004)

D : Voie des Gabales (Clément 2003)

E : Pénétrante Castelnau-le-Lez à Alès (Clément 2003) ; E-1 (Cavalier 1892)

F : Voie des Arvernes (Clément 2003)

\section{....... Ancient Paths considered as originally Roman}

$\mathrm{M} ; \mathrm{M}-\mathrm{a} ; \mathrm{Mb}$ : Chemin du sel - Malgoirès (Clément 2003)

$\mathrm{N}$ : Collectrice de Jalcreste, de Sommières-Tornac (Clément 2003)

O : Cami Salinié (Favory et al. 1985, Clément 2003)

P: Cami Roumieu (Favory et al. 1985)

\section{- Ancient tracks (from map and photo-interpretation)}

G ; H ; J (Bonnaud et Raynaud 1994)

I (Bessac et al. 1979) ; I-a (Bonnaud et Raynaud 1994) : I-c (Parodi 1987 , Boyer 2004)

L (Parodi et al. 1987, Boyer 2004)

M-1 (Parodi 1987) ; M1-c (Boyer 2004)

Ma-1 (Raynaud in Fiches ed. 2002)

Fig. 2 | Roads traditionally considered as Roman. 


\section{Optimal path implementation}

The factors and parameters taken into account in this work are mainly chosen according to the environmental characteristics of the interior of Languedoc: they are based on topography. The routes sought correspond to the least constraint path; in addition, the impact of a perceptual factor was tested: the field of view. To do so, two least cost path modelling methods were used.

\subsection{Optimal path factors}

From the perspective of travel by land, several categories of factors can be considered. First, we assume that the paths must be cost effective: they should enable fast movement, while energy consumption when travelling should be low. In fact, we assume that the difficulty of a journey was more important than travel time for the periods considered - especially since in the region the distance between the agglomerations in Roman times is only $25 \mathrm{~km}$ on average.

The basic constraints on movement are considered usually as topography (slope), as well as the existence of barriers such as rivers, or surface conditions (vegetation, a built road, swamp, etc.). However, apart from the difficulties related to our poor knowledge of hydrography and surface conditions in ancient times, ${ }^{2}$ we can consider these factors as secondary, to the extent that various construction techniques were used (bridges, land stabilization, forest clearance etc.). We do not aim to simulate the effect of movement of an individual in a given context, but to assess the strong constraints imposed by a space travelled frequently by communities. From this perspective, we can consider that the topography is the primary element.

Energy consumption also depends on the means of transport considered. To simplify the implementation, only pedestrian locomotion has been taken into account to set the least cost path modelling. Of course, the use of a cost function for wheeled vehicles would change the structure of the communication networks produced by theoretical modelling, due to different critical slopes (Herzog 2013). Nevertheless, we assume that a model based on pedestrian movement can already give a good assessment of the potential for the organization of the communication network.

Second, energy consumption is not the only variable that influences human travel (Llobera 2000; Wheatley / Gillings 2002, I5I, I55). For this study, we have considered that a

2 We know that in the study area river fords have moved significantly since the periods studied (Clément 2003 , 26), especially as a result of the hydrological system of this north Mediterranean karstic region. In addition, our knowledge of the palaeoenvironment is limited and it is still not possible to map ancient vegetation and wetlands reliably. 
path providing a good field of view will be preferred by travellers transporting goods - inert, or live, such as herds - for orientation and safety reasons. We assume that it is one of the factors in the establishment of roads in elevated places (as better perceptual conditions would counterbalance the topographical difficulties). When implemented, the "visual" factor is usually based on viewshed analysis (Lee / Stucky I998; Lu et al. 2008). We however prefer to apprehend this factor through the field of view (FOV). Like energy consumption, this factor is conditioned by topography (see infra).

\subsection{Slope-dependent least cost path calculation}

Various solutions have been proposed to weight the distances depending on slope (for a comprehensive review of the various algorithms used in archaeology see: Van Leusen I999; Van Leusen 2002, 6.5-6.7; Wheatley / Gillings 2002, I54-I56). Like others previously (Llobera 2000; Podobnikar et al. 2004), we relied on biometric measurements: the energy consumption values relating to movement on slopes were based on the results of a physiological study made on mountaineers (Minetti et al. 2002). The range of slope gradients given in Minetti's paper is quite broad, so we modelled intermediate cost values using a polynomial function of 3 rd degree.

The relative energy consumption calculated according to the slope value is an anisotropic parameter. Therefore, the slopes should not be considered as a set of fixed values, since the friction of movement is always dependent of the direction of movement: there are strong differences when walking up, down or along the slope. The problem of the difference between energy consumption walking up or down the slope is sometimes treated partially by introducing an offset on symmetric functions, so that the cost of walking down the slope is smaller than walking on flat terrain (Verhagen et al. I999; Van Leusen 2002, I6.IO-I6.I8). Some circumvent the issue by considering that a path is a round trip (De Silva ( Pizziolo 200I). However, it can be argued that, for a round trip, one would choose the best option by considering separately the costs for each direction; these costs cannot be reduced to an average cost, as has been proposed in some studies (De Silva / Pizziolo 200I). Moreover, it is also possible to follow different paths depending on the direction of movement.

Taking into account the direction of motion in path modelling has long posed technical difficulties. It is not enough to offer different cost values for walking up and down slopes, it is still necessary to know the direction in which the slope will be traversed during each trip. Some commercial GIS software allows anisotropic calculations, such as the ESRI's Path Distance method, which can calculate the effective slope for each combination of two pixels from their respective elevation values ("vertical relative moving angle": ESRI 2009). This effective slope is then transformed using a "vertical factor," which can be defined by a table correlating cost values with slope categories (in our case based from the energy expenditure values published by Minetti et al.). However, the integration of one or 


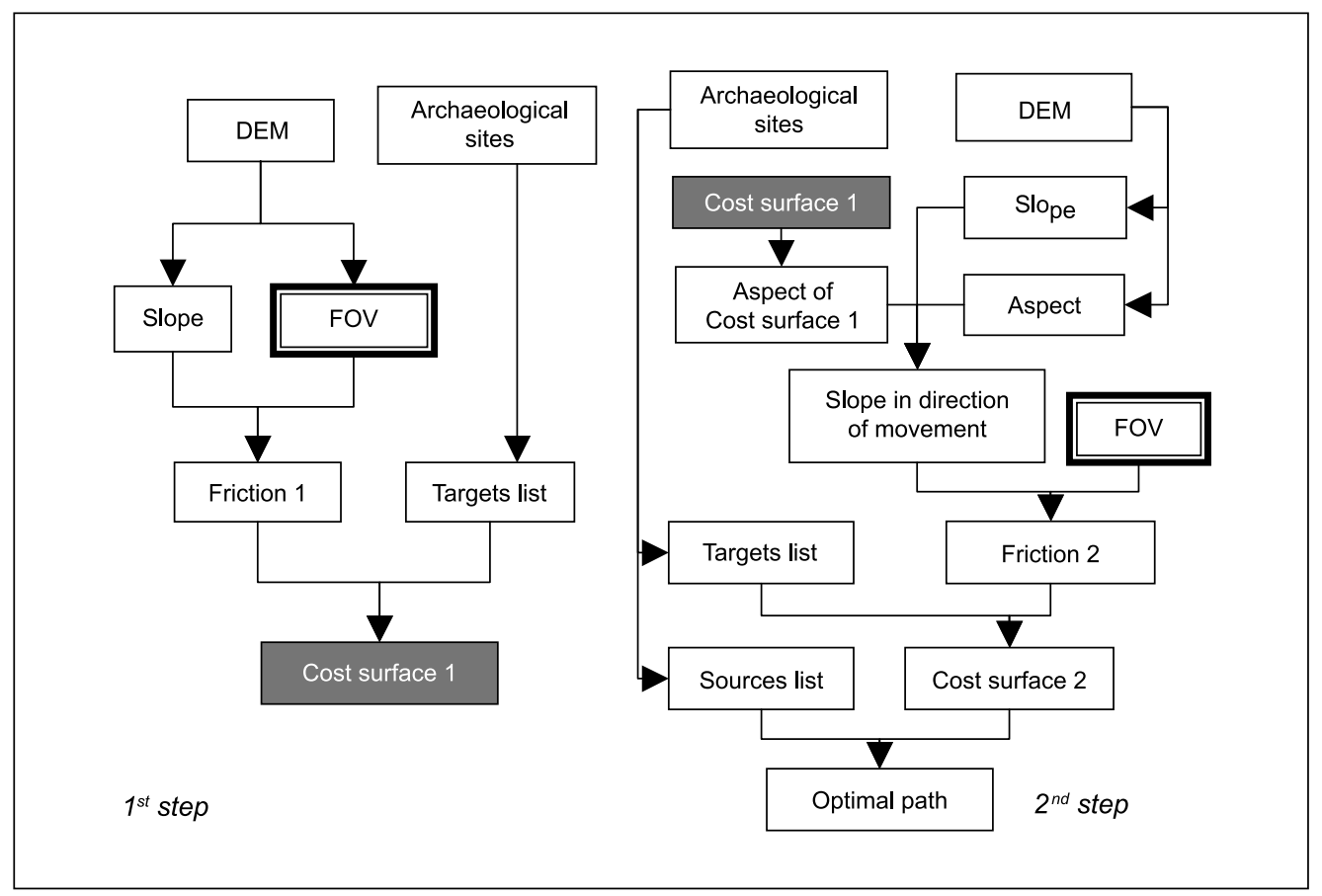

Fig. 3 | Proposed procedure for ancient path modelling.

more additional factor(s) affecting movement can be problematic, because this tool provides only one way to combine the effects of the slope and any other cost component(s), namely multiplication. Theoretically, there is no dependency between the parameters we have chosen; the FOV (field of view) factor is not more important on a steep slope than on flat terrain. Therefore, addition is a more suitable method of combination than multiplication.

Our approach proposes a specific anisotropic procedure: it considers the (approximate) direction of movement during the calculation of the friction surface. This procedure consists of two main steps (Fig. 3), in order to predict the approximate direction of movement between two places which might differ significantly from a straight line. The first step consists in computing a temporary accumulated cost surface (cost surface 1). In the second step the approximate direction of movement is estimated by the calculation of the aspect of the temporary accumulated cost surface; this allows us to calculate the effective slope from which we performed a final accumulated cost surface using an isotropic algorithm (ESRI's Cost Distance), and then the least cost path.

The calculation of the effective slope is based on the cosine of the difference between the aspect of the relief and the direction of the movement (aspect of cost surface 1). When the difference between the aspect and the direction of movement is equal to $90^{\circ}$ (i.e. when 


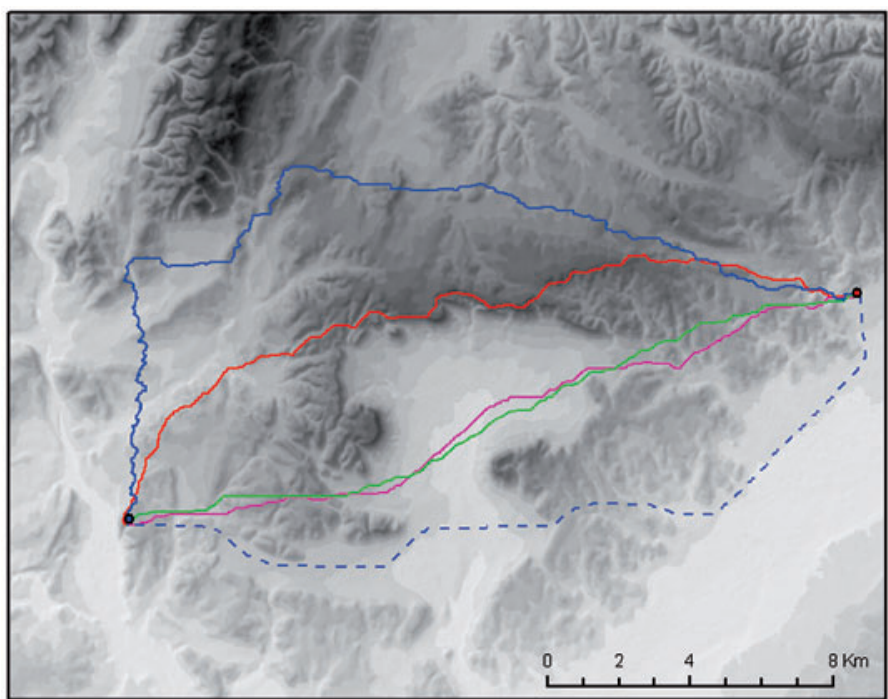

153045607590105120135150165195210225240255270285300

- Esri's isotropic method (costdistance)

- - Idrisi 3.2 isotropic method (cost)

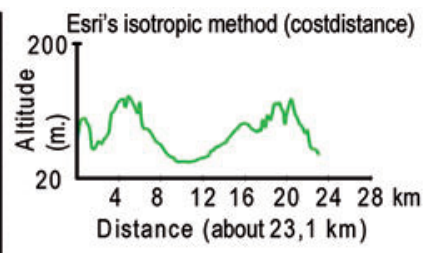

Esri's anisotropic method (pathdistance)

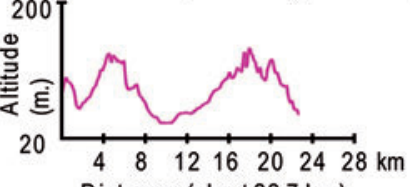

Distance (about 22,7 km)

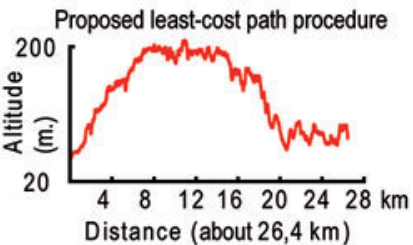

E. Fovet 2011

Fig. 4 | Comparison of the different least-cost path procedures.

walking along the slope) the recalculated slope is null, when this difference is equal to $0^{\circ}$ (i.e. when walking up the slope) the value remains unchanged, and when this difference is larger than $90^{\circ}$ (i.e. when walking down the slope) the recalculated slope has a negative value.

$$
\text { slope }_{\text {recalc }}=\cos \left(\text { aspect }_{\text {relief }}-\text { direction }\right) \cdot \text { slope }(\text { Zakšek et al. 2008) }
$$

The resulting paths are quite different from those obtained with the ESRI's Path Distance method (e.g. Fig. 4). They are "smoother," exhibiting fewer topographical variations than the ESRI's modules. In the region studied, consequently, the proposed procedure tends to generate elevated paths, following the ridges. In contrast, the Path Distance method generally produces quite straight paths, hardly influenced by the topography; this favours the transition into lowlands and narrow valleys. The analysis of all the modelled tracks (between a set of agglomerations) showed that the communication channels produced by these two procedures represent different types of paths that we also find in the actual landscape.

We consider that the differences with the ESRI's anisotropic method do not undermine our least cost paths procedure, although it is true that in very complex topographical 


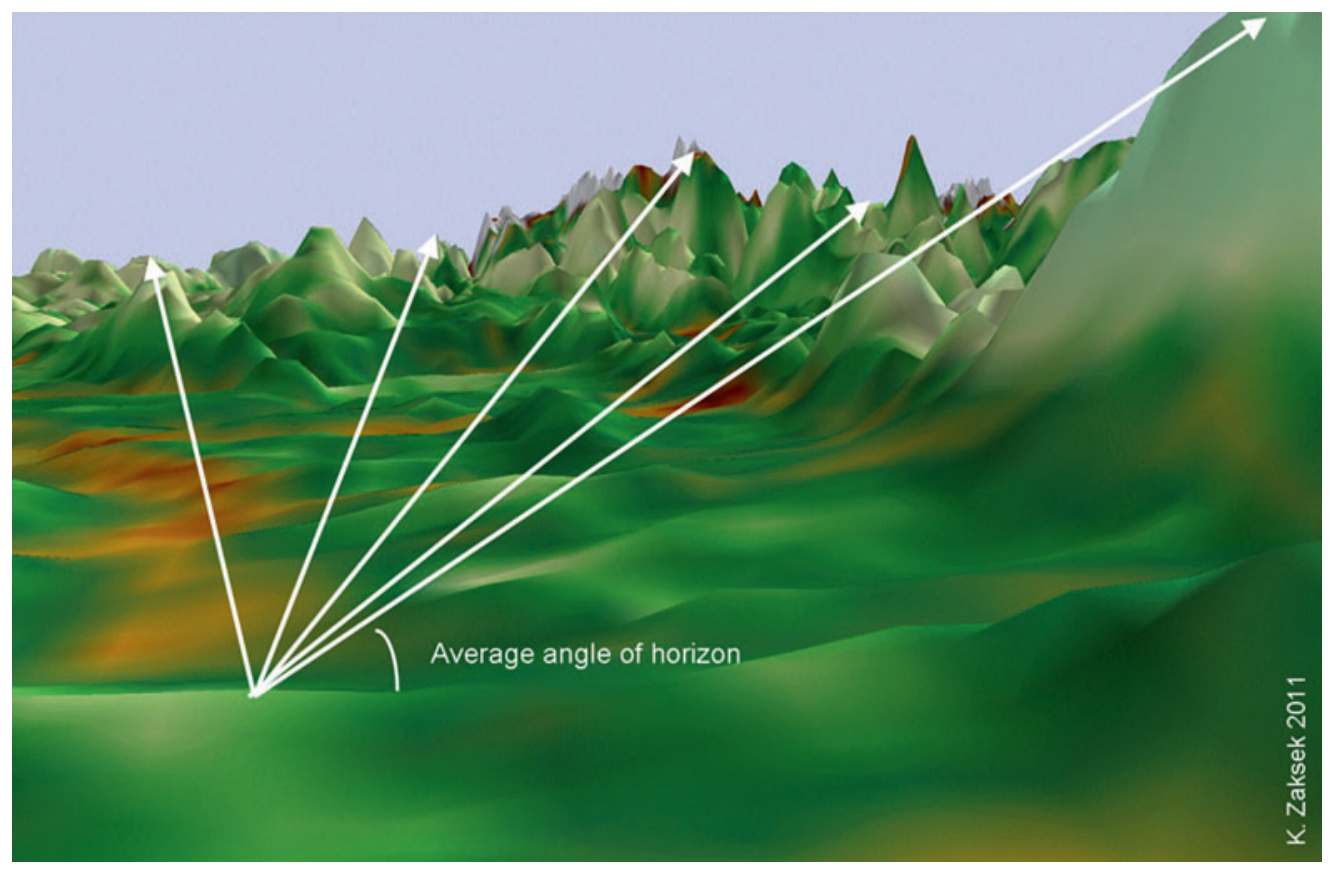

Fig. 5 | FOV as the average angle of horizon (drawing by K. Zakšek).

conditions (with craggy relief) our procedure causes unnecessary detours. In these rare cases, however, the introduction of the field of view (FOV) factor improves the model significantly.

\subsection{Introduction of the field of view factor}

The field of view (FOV) has been defined as the average angle of horizon (Fig. 5). It was computed by searching the horizon at the maximum distance of $7 \mathrm{~km}$ in 32 directions on $360^{\circ}$, with a methodology similar to skyview factor computation (Yokohama et al. 2002; Zakšek et al. 20II; Kokalj et al. 20II). Areas with the average angle of horizon close to zero do not have many obstacles in their horizon (such as plains, ridges etc.), and areas with a high average angle of horizon provide a low field of view (as in narrow valleys or piedmonts).

In order to obtain optimal paths that take into account both the effect of the slope and the impact of the field of view, the friction surface was calculated as a sum of the FOV and the relative energy consumption weights (see supra). However, the impact of the FOV on 
human decisions about movement is not measurable. It is hence essential to evaluate the combination of the FOV and energy consumption factors. We computed several models, changing the weight of the field of view:

In the first model, the FOV was set to I; this model yields a very poor influence by the FOV, as its values are much lower than the energy consumption ones - FOV values range from I to 27.7 , with a mean of 2.87 , while those of energy consumption range from 24 to 356 , with a mean of 33 . A second model was produced using a FOV weight of 5 ; the values of this layer are still two times lower than the energy consumption ones. In the third model, FOV weight was set to Io, which yields a strong influence by the field of view since the values of the two factors are then similar. In the fourth model FOV weight was set to 20 ; the values of this layer are two times higher than the energy consumption ones.

The introduction of the FOV to the modelled tracks gathers the paths either on the ridges or in the centres of plains and basins.

\section{Assessment of the models}

\subsection{Comparison with roads previously proposed as ancient}

Path modelling validation is a difficult issue. The relationship between network models and roads considered as ancient (e.g., presumed Roman) is ambiguous: if a modelled channel does not fit the presumed path for a given route, one cannot really know if that is because the model is erroneous or because the route traditionally proposed corresponds to another period or another level in the road network (local roads and inter-regional roads vs. regional communication channels). The status of roads implies specific routes, because the main purposes are different (e.g., supra-local roads do not aim to connect all local places), the level of engineering and the organization are variable and the modalities of transport can also be different (pack animals vs. wheeled vehicles for bulky goods). Inevitably, several alternative routes existed and our modelled networks are designed to locate only one of them. Thus, at the present state of studies on ancient roads in Languedoc, optimal path modelling cannot really be tested against the roads considered to be ancient; conversely, however, models can provide an analysis of the roads considered to be ancient.

The Via Domitia is an interesting example for the problem of the confrontation between the road network models and the known ancient roads. We know that this interprovincial road was constructed during the 2 nd century BC (see supra); however, it is now generally considered that this was even then an adaptation of a pre-existing route (Py I990, 623; Clément / Peyre I99I, I5-25; Castellvi et al. I997, I6; Py/Vignaud I998). In our region, its path can be divided into two parts (see Fig. 2): the section Sextantio-Ambrussum and the section Ambrussum-Nîmes. Close to Nîmes, its precise location is subject to discussion (Fiches I985, 136-138; Fiches I997, 63; Laforgue et al. 1997, 24). 


\begin{tabular}{|c|c|c|c|c|c|c|c|c|}
\hline 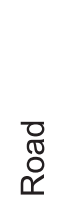 & 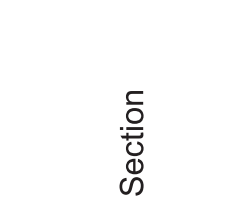 & 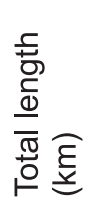 & 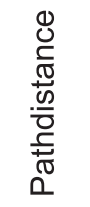 & 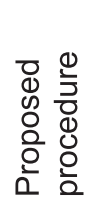 & 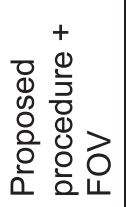 & 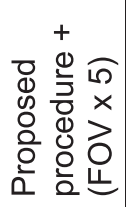 & 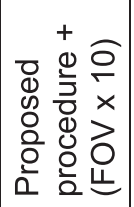 & 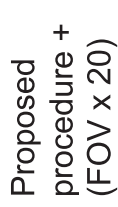 \\
\hline A & $\begin{array}{l}\text { Sextantio- } \\
\text { Ambrussum }\end{array}$ & 21.9 & 20.2 & 21.4 & 17.5 & 16.4 & 11.9 & 7.3 \\
\hline A & $\begin{array}{l}\text { Ambrussum- } \\
\text { Nîmes }\end{array}$ & 20. 9 & 3.7 & 1.7 & 1.5 & 15.2 & 15.5 & 15.6 \\
\hline A & $\begin{array}{l}\text { Ambrussum-La } \\
\text { Condamine- } \\
\text { Nîmes }\end{array}$ & 20.9 & 17.9 & 11.7 & 12.9 & 13.4 & 15.5 & 15.6 \\
\hline A-1 & $\begin{array}{l}\text { Ambrussum- } \\
\text { Nage-Nîmes }\end{array}$ & 17.6 & 11.1 & 11.8 & 11.1 & 6.7 & 6.8 & 6.9 \\
\hline
\end{tabular}

\begin{tabular}{|l|l|}
\hline & $>75 \%$ of the total length \\
& $>50 \%$ of the total length
\end{tabular}

Fig. 6 | Length of the longest optimal path segments of the network that follow the Via Domitia (with a tolerance of $500 \mathrm{~m}$ ).

The Sextantio-Ambrussum section of the Via Domitia is followed, by and large, by the various optimal paths between these two towns (Fig. 6), with the exception of those from the model strongly influenced by our visual factor (FOV set at 20 ). In contrast, to model the path of the Ambrussum-Nîmes section, it seems necessary to integrate the FOV with a significant weight - directing the optimal paths in the open plain. For the other models the only way to reconstruct the Via Domitia correctly is to take into account the small town of La Condamine as a stopping point. Archaeologists usually consider that the section connecting Ambrussum to Nîmes has changed over time. According to J.-L. Fiches (Fiches I985, I36-I38; Fiches 1997, 63) its passage in the plain could not have been put in place before the layout of the cadastre "Nîmes A" to which the road fits securely, that is to say from the Ist century $\mathrm{BC}$ on. It was proposed as early as I930 (J. Igolen) that the pre-Roman path passed via the oppidum of Nages, $5 \mathrm{~km}$ to the north of the Via Domitia (see Fig. 2, road A-I). This proposed pre-Roman route is more readily reproduced by the paths from our least cost procedure (without the integration of the FOV): optimal path segments are a bit longer, but mostly much denser.

Concerning the rest of the road network, we observe that, in general, optimal paths follow approximately the tracks of the roads considered to be ancient ${ }^{3}$ (Fig. 7), although they do not always correspond to dense channels. The communication channels produced by the Path Distance method correspond better to the presumed inter-regional Roman roads

Only roads E, N, O and B are not well represented. 


\begin{tabular}{|c|c|c|c|c|c|c|c|c|}
\hline 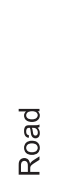 & 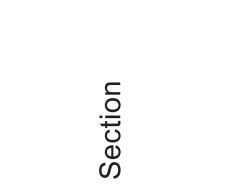 & 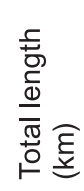 & $\begin{array}{l}0 \\
0 \\
\frac{0}{\pi} \\
\frac{0}{00} \\
\frac{0}{0} \\
\frac{E}{\pi} \\
0\end{array}$ & 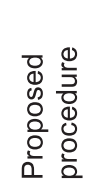 & 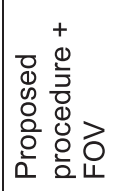 & 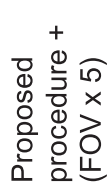 & 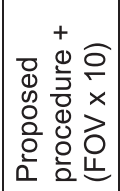 & 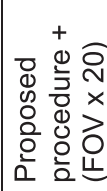 \\
\hline B & & 48.8 & 15.5 & 12.6 & 12.0 & 8.9 & 7.7 & 7.8 \\
\hline C & Mus-Prouvessa & 16.5 & 14.9 & 3.3 & 7.3 & 10.7 & 8.5 & 6.1 \\
\hline C & $\begin{array}{l}\text { Prouvessa- } \\
\text { Nîmes }\end{array}$ & 20.3 & 14.4 & 8.7 & 11.7 & 14.7 & 9.3 & 10.5 \\
\hline D & & 31.0 & 20.1 & 3.7 & 4.1 & 15.2 & 15.4 & 11.2 \\
\hline $\mathrm{F}$ & & 19.3 & 9.4 & 4.9 & 4.2 & 10.9 & 4.5 & 4.5 \\
\hline$E$ & & 52.2 & 17.8 & 9.8 & 9.7 & 9.2 & 9.4 & 8.3 \\
\hline E-2 & & 18.3 & 5.5 & 7.1 & 6.8 & 7.1 & 7.8 & 6.9 \\
\hline B-1 & & 15.8 & 9.3 & 4.7 & 3.3 & 4.0 & 3.4 & 3.4 \\
\hline G & & 17.9 & 8.5 & 5.3 & 4.0 & 13.4 & 9.2 & 8.4 \\
\hline $\mathrm{H}$ & & 7.9 & 3.6 & 7.9 & 7.0 & 6.7 & 6.9 & 6.7 \\
\hline 1 & & 17.2 & 2.6 & 10.2 & 11.4 & 6.5 & 3.4 & 3.0 \\
\hline I-a & & 7.2 & 2.6 & 6.0 & 6.0 & 5.2 & 0.0 & 0.0 \\
\hline $\mathrm{I}-\mathrm{b}$ & & 8.1 & 0.0 & 3.2 & 6.7 & 4.3 & 6.5 & 6.2 \\
\hline I-C & & 22.1 & 7.8 & 4.7 & 9.3 & 2.1 & 2.1 & 2.1 \\
\hline J & & 8.0 & 6.3 & 4.3 & 4.3 & 5.9 & 5.8 & 7.4 \\
\hline K & & 16.8 & 11.9 & 6.6 & 8.3 & 5.1 & 0.0 & 0.0 \\
\hline $\mathrm{L}$ & & 16.2 & 11.5 & 5.5 & 5.7 & 4.9 & 4.4 & 4.3 \\
\hline$M$ & & 15.8 & 15.7 & 4.2 & 2.4 & 5.7 & 3.0 & 3.0 \\
\hline M-a & & 26.4 & 13.6 & 11.6 & 13.7 & 16.2 & 13.8 & 14.0 \\
\hline$M-b$ & & 25.1 & 10.4 & 8.2 & 12.5 & 7.3 & 4.8 & 7.4 \\
\hline $\mathrm{N}$ & & 24.8 & 8.1 & 4.0 & 4.5 & 5.4 & 4.5 & 6.3 \\
\hline 0 & & 54.5 & 10.8 & 8.2 & 8.2 & 8.0 & 8.1 & 11.0 \\
\hline$P$ & & 21.6 & 10.5 & 6.3 & 8.7 & 11.3 & 6.4 & 6.4 \\
\hline
\end{tabular}

$>75 \%$ of the total length $>50 \%$ of the total length

Fig. 7 | Length of the longest optimal path segments of the network which follow the roads previously proposed as ancient (with a tolerance of $500 \mathrm{~m}$ ). 
(roads C, D and F). Regarding the other types of road, some are better represented by this model (B-I, K, L and particularly the ancient salt roads M), while others are better represented in the networks modelled using our least cost path procedure ( $\mathrm{G}$ and particularly $\mathrm{H}$ and the transhumance paths I). Considering the specificities of the paths modelled by our procedure, it is not surprising that they are the only ones that fit to the ridge paths $(\mathrm{H}, \mathrm{I}$ and I-a).

These comparisons let us see that no model alone can approach the complex ancient road network; the use of several models completing each other is needed. In some cases historical reconstitution of a single road requires that different parameters be modelled. For example, the section Nîmes-Nages of the inter-regional road B is best fitted by our procedure when the visual factor is given no, or a very small, weight (FOV set at o or I). Its Nages-Villevieille section is followed only by the Path Distance model. For the section Villevieille-Puech des Mourgues, models using our procedure are the best (especially with FOV set at I or 5).

As a further step, the analysis of optimal path network modelling at regional scale shows that some inter-regional roads are likely formed by connecting up separate regional routes. Let us take the example of the road D, which connects Nîmes to Anderitum (nowadays Javols in Lozère): its section between Nîmes and the massif of Bois des Lens (in the north of La Jouffe) is represented in the majority of the models (Path Distance, models with FOV set at 5, Io or 20) as a portion of the route between Nîmes and Mus. We can therefore propose that this section of the inter-regional road D corresponds primarily to the regional roads from Mus to Nîmes, to which the route from Anderitum would connect.

The road $\mathrm{C}$ also seems to be composed of the regional routes from Nîmes to Prouvessa and La Jouffe on one hand, and from Mus to Mauressip, Nage and Espeyran on the other hand. The connection between these two sections is poorly represented by modelling pathways between the regional centres. It is therefore interesting to note that in the area where these regional networks connect (south of Prouvessa) this road makes a detour (Fig. 8). This area is also marked by a Late Roman funerary area and the proximity of a Roman and Late Roman settlement. This detour is obviously not caused by the topography and could well be an artefact of the evolution of the road network. In fact, the segment oriented southeast to northwest of this anomaly corresponds to the channels connecting the oppida La Jouffe and Mauressip, which serve a set of iron ore processing sites and high quality stone quarries in the massif of Bois des Lens (Fig. 8).

We can therefore assume that the linkage of the two old roads has been influenced by the existence of other routes passing nearby. At present, there is no element that would allow us to fully understand this phenomenon of interaction between the different levels of roads (local, regional ...): only more data for the southwest to northeast communications would be able to support this hypothesis. In any case, the comparison between this road and the network models suggests that the axes of passages in this sector are complex; the 
Modelled channels: example of the proposed procedure with FOV $\times 5$

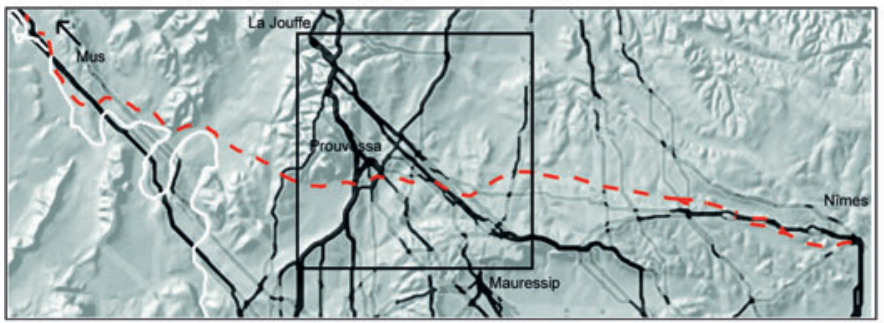

Modelled channels: example of Esri's procedure (pathdistance)

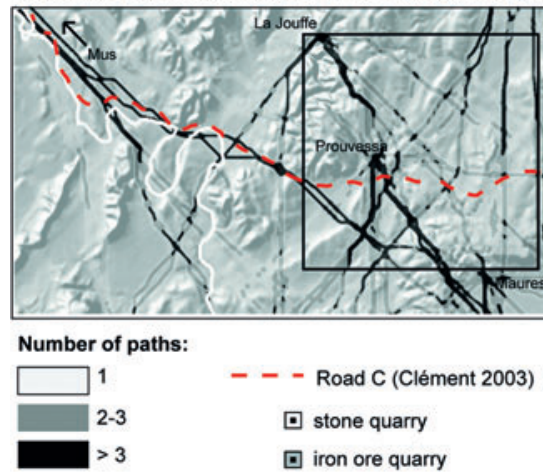

iron ore quarry
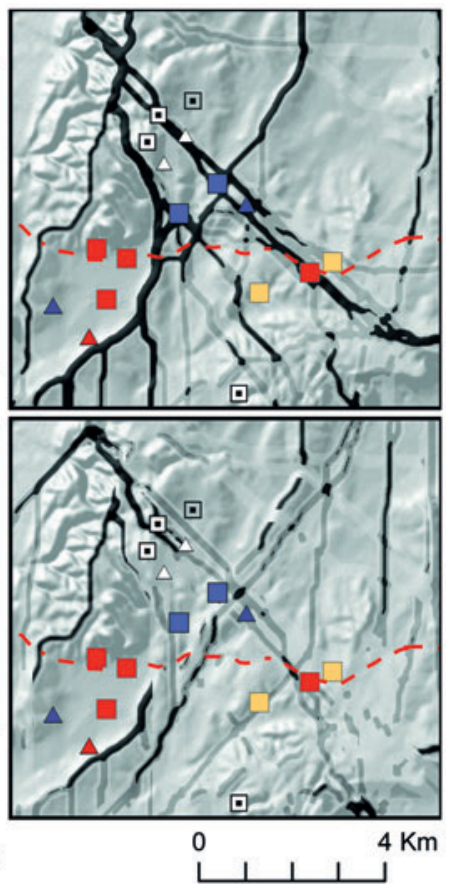

Fig. 8 | Enlarged view of road $\mathrm{C}$ and the modelled channels.

tracks could have swung between the attraction of long-distance networks and the logic of regional or local communications, and could well have had a story much more dynamic than is indicated by the regression analysis of the road network.

The confrontation between the road network models and the roads considered as ancient raises interesting questions but, as we said above, it does not help to validate or invalidate the different models.

\subsection{Comparison with the settlement pattern}

Another way to evaluate the different regional road network models is to observe their consistency with the entire settlement pattern at different periods. Indeed, it can be assumed that the road network was a significant factor for the choice of location of many sites. For a farm, the vicinity of a major road made it possible to market its produce more easily and probably lowered the financial cost of transport. Latin agronomists paid special attention to the "commodity" of transport in the rural economy: 
A handy road contributes much to the worth of land: first and most important, the actual presence of the owner, who will come and go more cheerfully if he does not have to dread discomfort on the journey; and secondly its convenience for bringing in and carrying out the necessaries - a factor which increases the value of stored crops and lessens the expense of bringing things in, as they are transported at lower cost to a place which may be reached without great effort; and it means a great deal, too, to get transportation at low cost if you make the trip with hired draught-animals, which is more expedient than looking after your own; furthermore, that the slaves who are to accompany the master will not be reluctant to begin the journey on foot. (Columella, RR I, transl. H.B. Ash I94I).

In order to evaluate the models we calculated the frequency of archaeological sites 4 in a range of distance bands from the main communication channels, for four different periods which represent the major phases of evolution of the settlement pattern in this region: the

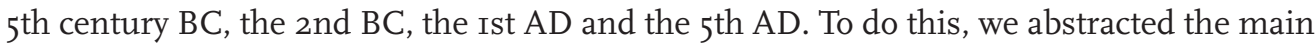
channels from the path networks obtained, using the density 5 of paths. We started by mapping the densest channels (which represent 5 or 6 paths, or 4 paths for certain periods), then we proceeded by completing gaps in these main pathways by following the most dense channels in between (usually 3 or 4 paths, or sometimes 2 paths). In certain cases, where two agglomerations were not connected with this procedure, we lowered the first threshold ( 3 or 4 paths). We restricted this analysis to the core of the study area (Fig. I); this subset of $452 \mathrm{~km}^{2}$ is free of border effects and corresponds to the hilly zone of the interior of Languedoc (the type of environment for which the model was developed) where the archaeological data are most reliable.

Except for the $5^{\text {th }}$ century BC, a proportionally large quantity of sites is situated at less than $800 \mathrm{~m}$ from the main modelled channels, while in zones at more than $\mathrm{I} 200 \mathrm{~m}$ the number of archaeological sites declines (Fig. 9). About $40 \%$ of the sites are situated in one of the first two ranges of distance in most periods. We note that this percentage is quite stable despite the strong variation in the numbers of sites between the different periods. Indeed, there are ten times more sites occupied in the ist century AD than during the 2nd century BC, but the proportions of sites inside the corridors are similar.

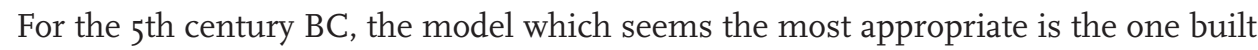
with our least cost path procedures without taking into account the visual factor (FOV weight set at o). For all other periods, the "Path Distance model" is the one that has most sites in the corridor of $400 \mathrm{~m}$, while our least cost path procedures obtain better correlation between $400 \mathrm{~m}$ and $800 \mathrm{~m}$ when the visual factor is given no, or a very small, weight (FOV set at o or I). Models that take into account the FOV significantly (weight of 5 or Io) are suitable for the 2 nd century BC and ist century AD, but less so for the $5^{\text {th century AD. }}$

4 Excluding those used as nodes to model the optimal path network.

5 Defined by kernel density of optimal paths within a radius of $125 \mathrm{~m}$. 

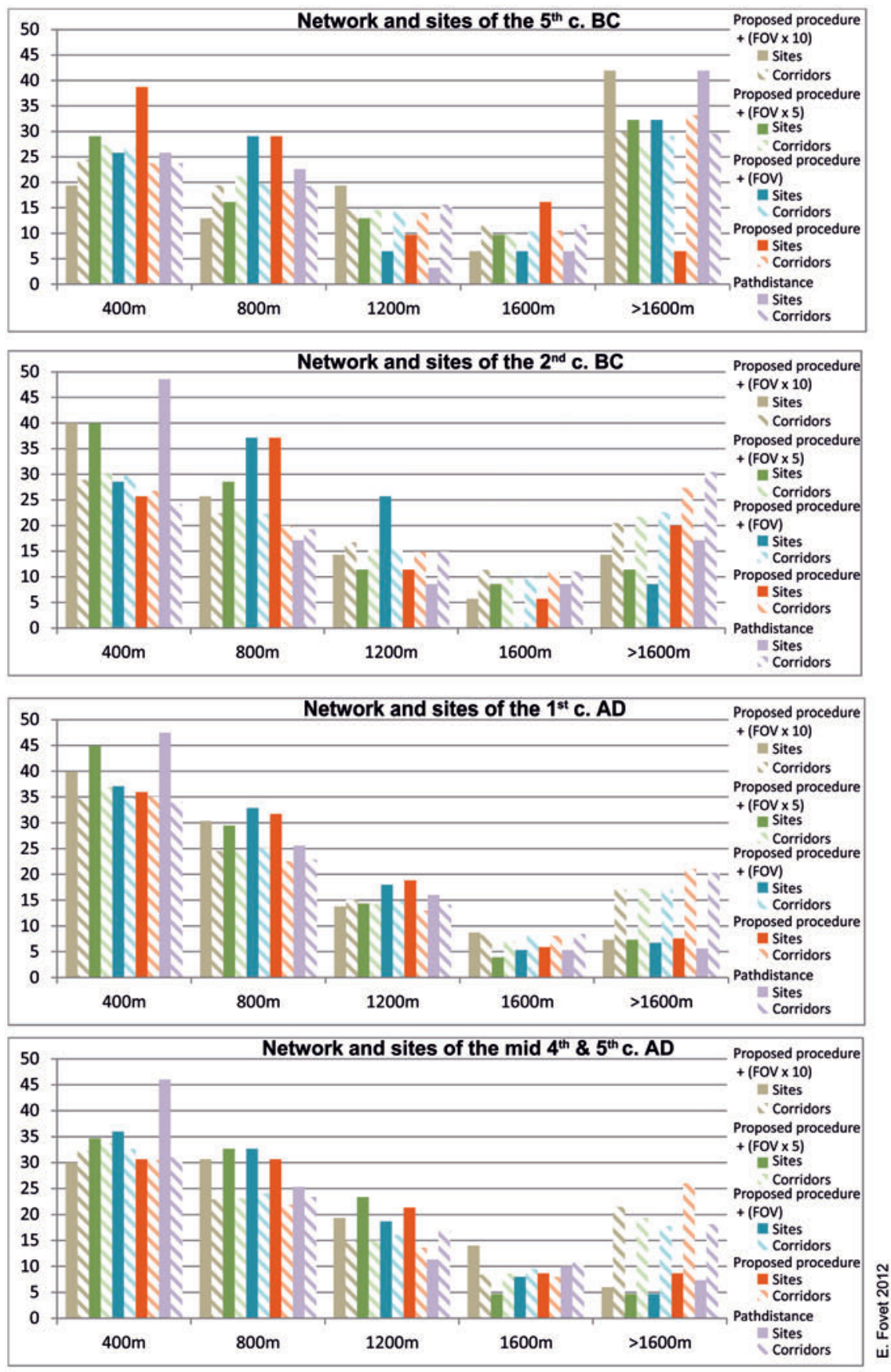

Fig. 9 | Road network models and settlement pattern: proportions of sites located in distance bands from the main communication channels (plain colours) and proportions of landscape taken up by these zones (hatched colours). 
A relationship appears between the types of sites $^{6}$ and the network models (Fig. IO). For the prehistoric periods, it is difficult to determine whether the various models concern specific types of sites, because the number of sites is low. One can nevertheless note that in the and century BC ephemeral sites (class A) predominate in the models in which the visual factor is given no, or a very small, weight (FOV set at $\mathrm{O}$ or $\mathrm{I}$ ), while class B is slightly overrepresented in the vicinity of the "Path Distance model".

In the ist century $\mathrm{AD}$, distributions of classes for each model are quite similar to the analysed corpus. One can nevertheless note that modest settlements (class A and B) tend to be over-represented in the models from our procedure, whereas this tendency is reversed for the "Path Distance corridors," where class E (higher status settlements) and C (medium size settlements occupied for a long time) are better represented. For the end of the 4 th and during the $5^{\text {th }}$ century $\mathrm{AD}$, distributions of classes for each model show stronger differences. Higher-status settlements (class D and E) are better correlated with models without a visual factor, while smaller and short-lived sites (class A or B) are under-represented. Conversely, in the vicinity of models that integrate the visual factor significantly (FOV multiplied by 5 or Io), ephemeral sites (class A) are clearly over-represented while long-lived and large settlements (class C and D) are scarcer.

Overall, these two sets of charts show that from the 2nd century BC on, we observed far more small and ephemeral sites in the vicinity of the network models that integrate the visual factor and therefore favour elevated places or mid-plain, especially the model where the FOV is multiplied by 5 . In contrast, the network of pathways that is relatively uninfluenced by the topography and which favours the transition into lowlands (produced with the Path Distance method) is more strongly related to large and sustainable settlements. This suggests that we modelled two types of network that seem to have had separate functions, since they not only reflect different ways of moving, but also appear to serve specific categories of archaeological sites. This phenomenon may be related to rural activities, such as pastoralism, but the characteristics of settlements attached to these models should be studied in greater detail before proposing a firm link to this type of path network.

These results let us consider the coexistence of two different kinds of network, each governed by a specific logic of movement (and probably with different aims and means of transport). Therefore, we decided to use the two most typical models to study the evolution of these regional path networks: a "model A" built with Path Distance and a "model B," which corresponds to the model that integrates the visual factor and which proved to be the most attractive, or specifically related, to ephemeral sites, i.e., the model that gives a moderate but significant weight to this factor (FOV weight set at 5).

6 This analysis uses the results of a classification of the settlements (from the 7 th century BC to the 7 th century AD) made on a supra-regional scale (using a corpus localized in different micro-regions in southeast and central France) during the ArchaeDyn 2 programme (Bertoncello et al. 20I2). This classification is mainly built on the highly discriminating variables "surface" and "duration of the occupation" of the settlements. 

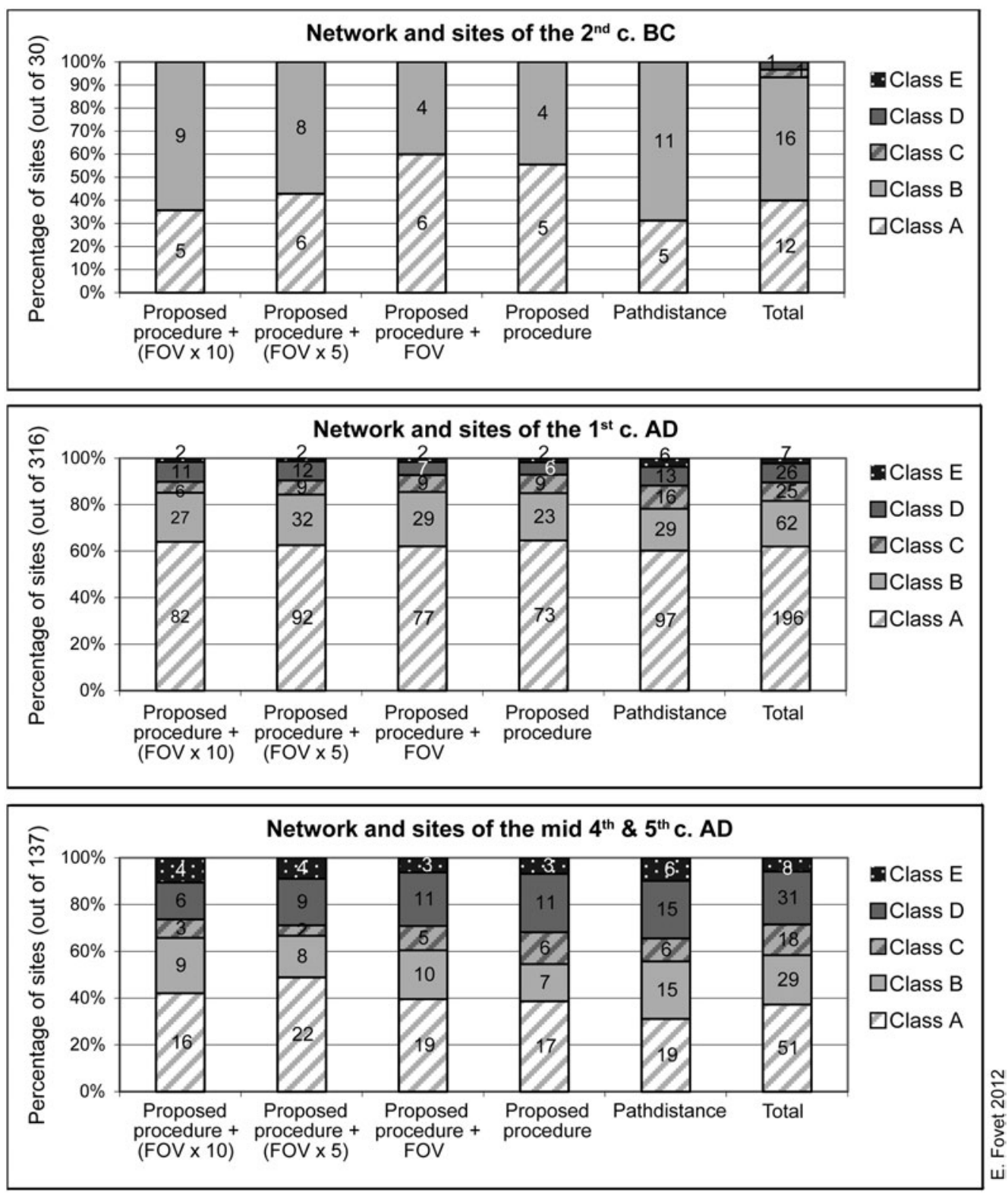

Fig. 10 Road network models and settlement pattern: types of sites located in a corridor of $400 \mathrm{~m}$ from the main communication channels (hierarchical classification from ArchaeDyn2 programme). 


\section{Evolution of the optimal path networks}

The evolution from the $5^{\text {th }}$ century BC to the Ist century AD of the distribution of the agglomerations produces only very slight changes in the configuration of the regional optimal path network in both models (Fig. II and Fig. I2). This apparent stability shown by the optimal path models over these periods suggests that new agglomerations did not really change the structure of the road network but more likely completed it. The oppida of the second Iron Age (settled between the late $4^{\text {th }}$ and early 3rd centuries BC) as well as the small towns created during early Roman times (from the end of the Ist century BC and especially during the early ist century AD) were established along the previous communication channels (especially in model A). This suggests that the major settlements created during these periods were established in the vicinity of ancient roads. Thus these centres seem to have benefited from pre-established communication structures, and did not necessitate the construction of additional roads to trade and exchange with other important places.

However, the establishment of these early Roman towns also seems to have influenced the appearance of (or at least reinforced the existing trend of) alternative routes to the previous agglomerations. This tendency is more pronounced in model B. This phenomenon is particularly noticeable in the case of the oppidum of Ambrussum, around which the network model B forms four points of intersection within a radius of $3 \mathrm{~km}$ (Fig. I2). The existence of alternative pathways is indeed likely in this case, as it may be that travellers wanted to avoid the legal constraints (passage fee) probably associated with crossing the river by the bridge7 at the foot of the oppidum. Therefore we can assume that alternative channels (type B) coexisted with tracks connecting the oppidum to the other regional centres (notably the Via Domitia linking Nîmes to Sextantio and Lattes).

Beyond the overall stability of the network suggested by the optimal path models, the question that emerges concerns the role of new centres in the agglomeration network: were the new towns complementary to or competitors of the ancient ones?

The cases of Ambrussum and Lunel-Viel are interesting in this respect. Lunel-Viel was established to the southwest of Ambrussum, in the middle of the Ist century AD, at the intersection of pre-existing communication channels of the model A (Fig. II), and where the alternative channels in the model B meet (Fig. I2). This let us consider that the establishment of Lunel-Viel resulted in channelling this second type of flow (B), probably on the track of road P (see Fig. 2 and Fig. 7). Therefore, Lunel-Viel would have had the effect of helping to better control the traffic circumventing Ambrussum. This hypothesis seems to be confirmed by the topography of this very small Roman town (Fig. I3): the road Cami roumieu (road $\mathrm{P}$ ) penetrated from the east to the heart of the town and led to a large dead end furnished with monumental architecture, which suggests strong flow control on this road.

On this Roman bridge see Vial 2003, 390-39I, $n^{\circ}$ I-I 

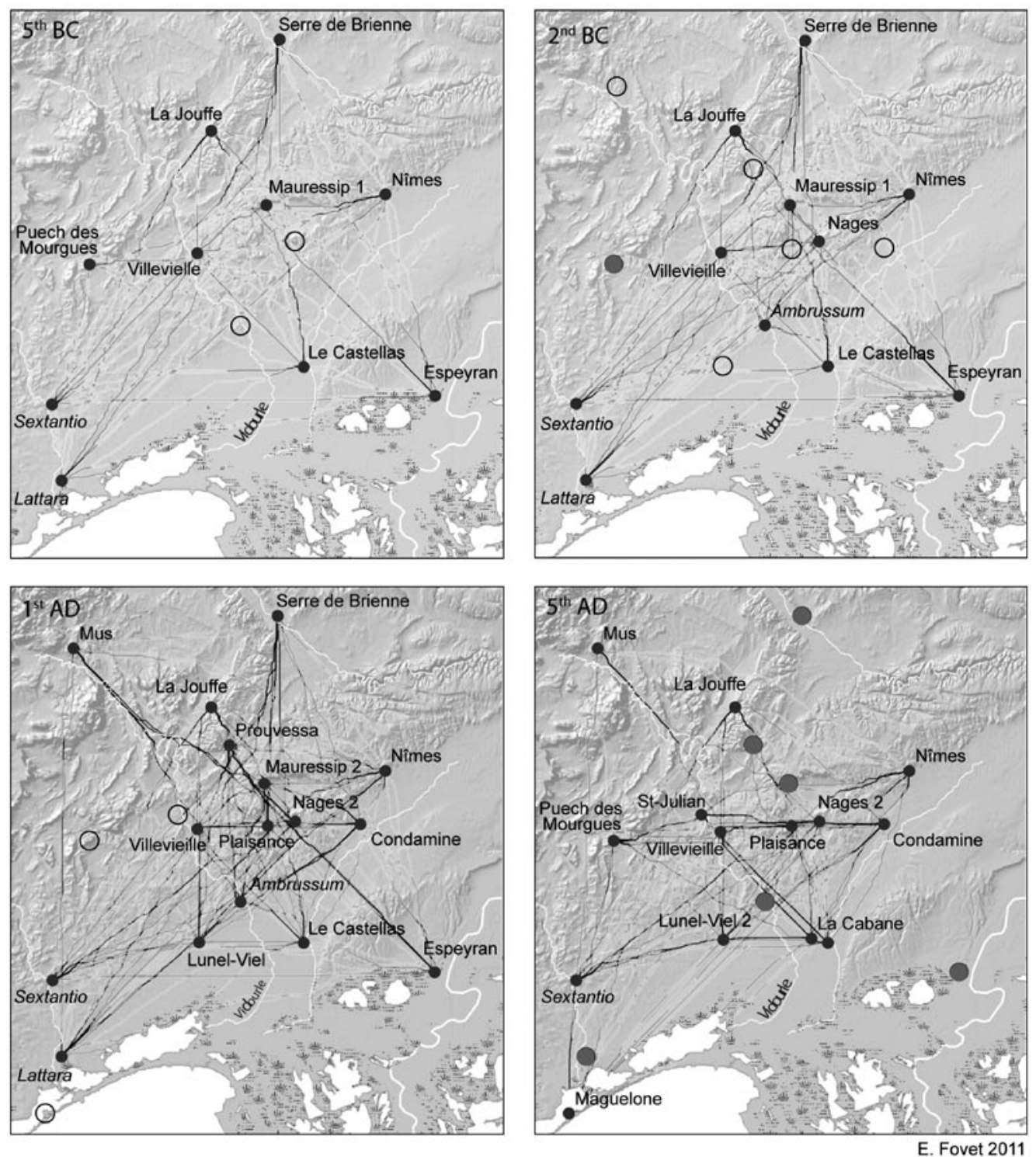

- Agglomeration

Agglomeration of the next period

- Former agglomeration
Number of optimal paths :

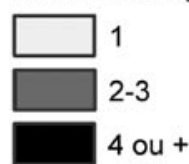

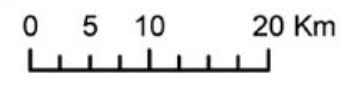

Fig. 11 Road network models from the 5th century BC to the 5th century AD: model A. 

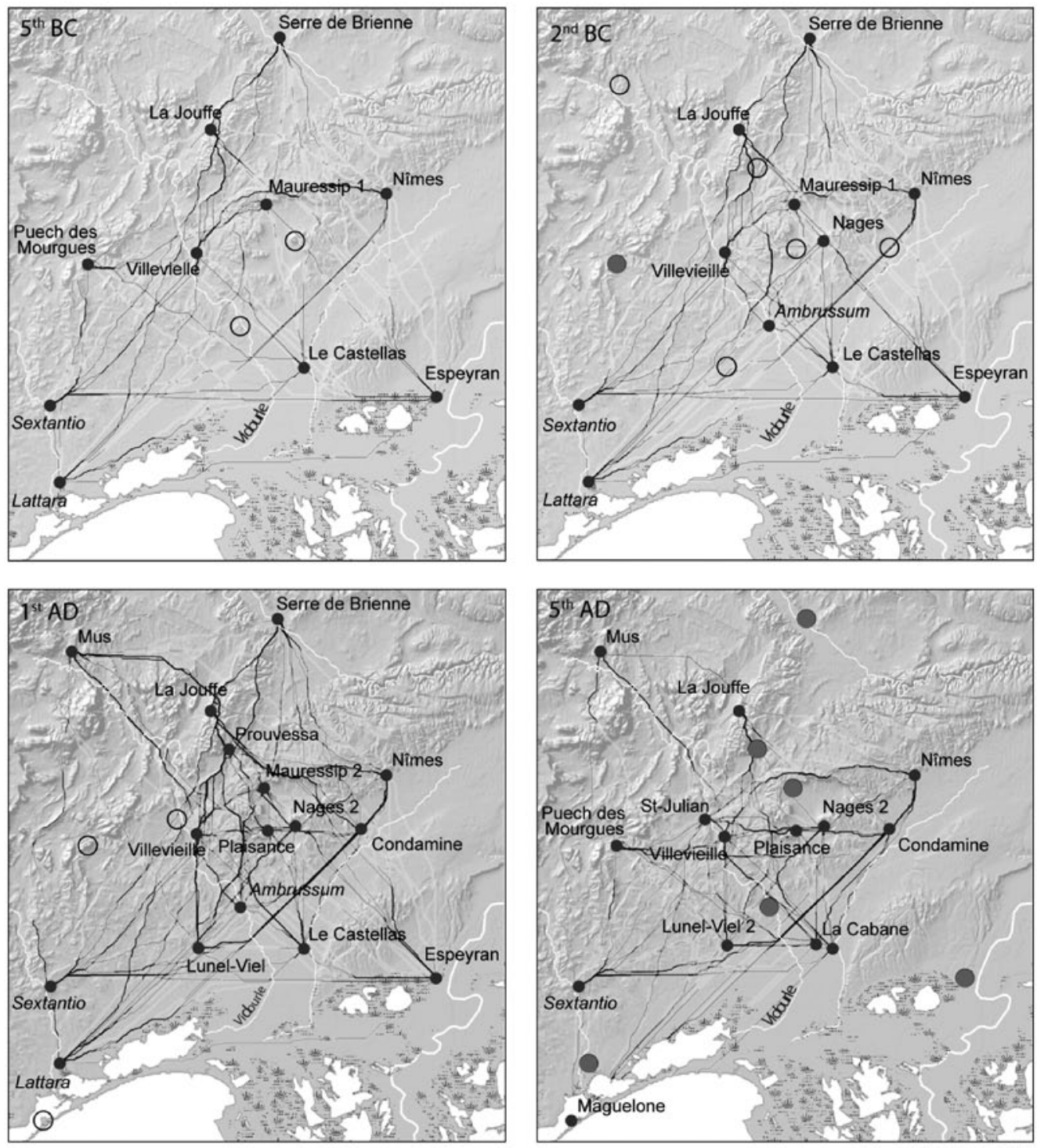

E. Fovet 2011

- Agglomeration

Agglomeration of the next period

- Former agglomeration
Number of optimal paths :
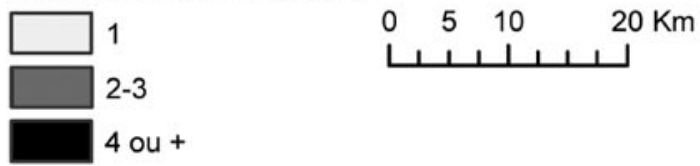

2-3

4 ou +

Fig. 12 | Road network models from the 5th century BC to the 5th century AD: model B. 


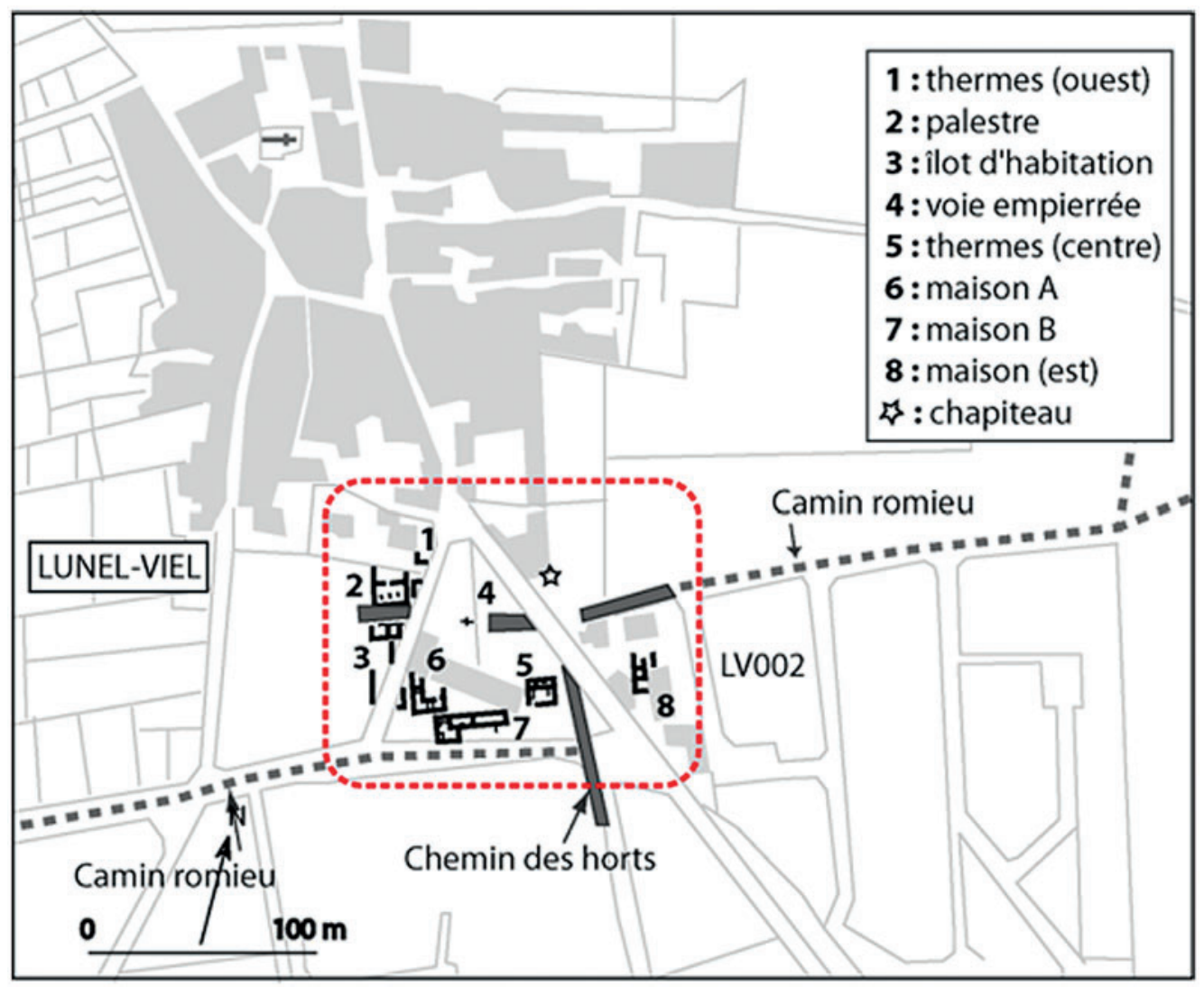

Fig. 13 | Lunel-Viel: spatial extent of the Roman town and roads serving the site (extract from Ouriachi 2009, vol. 2, from Raynaud I990 and Raynaud 2007).

From this point of view the new agglomeration seems to complete the role of the older centre. However, one may also wonder if, on the contrary, Lunel-Viel would not have rather had the effect of weakening the position of Ambrussum by reinforcing the alternative channels, especially since Villevielle, which is located further upstream, developed strongly from the ist century AD.

On any scenario, there are parallels between the histories of Ambrussum and LunelViel. Ambrussum witnesses great vitality in the Ist century BC, but the upper city was abandoned around the beginning of and century AD, and only the road station located at the foot of the hill, where the Via Domitia passed by, lasted longer. In contrast, Lunel-Viel was created in the middle of the Ist century AD and witnesses a phase of intensification in the middle of the 2 nd century AD (followed by stability until the middle of the 3rd century AD). Therefore, the decline of Ambrussum could be related to the potential competition exerted by Lunel-Viel (and other places?) at regional scale; or, at the least, the regional role of Am- 
brussum in the road network could have been transferred to Lunel-Viel. The existence of a long-distance communication axis (the Via Domitia) does not seem to have been sufficient to maintain the economic vitality of the oppidum: the place turned into a stopping point only. Path modelling cannot explain the decline of Ambrussum, but shows the likely role of the road network in the relationship between this site and Lunel-Viel. This aspect was not fully taken into account before, because the question of the roads was only addressed by the analysis of the roads traditionally regarded as ancient, which recognizes no direct connection between these two sites (see Fig. 2).

This example shows that optimal path network modelling can give new perspectives on the changing pattern of agglomerations: it leads us to rethink the relationship between these major settlements, and to reassess their relative position in the trade networks.

For the Late Roman period, the changes in the pattern of agglomerations do not seem to have a strong impact on the structure of the communication network either (Fig. II and Fig. I2). The abandonment or decline of several originally indigenous aggregated settlements between the end of the Ist century AD and the middle of the 2nd century AD produce only a decrease in the density of certain modelled channels, while the settling of StJulian during the 3 rd century AD and the reoccupation of Puech des Mourgues in the middle of the $4^{\text {th }}$ century AD has only the effect of increasing the density of the east-west channels in the hinterland. This relative stability is partly due to the phenomena of slight displacements of population centres that do not affect the path network models - such as from Lunel-Viel to Lunel-Viel2, Lattes to Maguelonne, Le Castellas to La Cabanne and probably from Espeyran to another nearby site not included in the models because of uncertainties (St-Gilles). In addition, if the site of Puech des Mourgues did not appear very well integrated in the previous regional communication networks, St. Julian is located near a very old communication channel, which is found in the various prior network models. This stability suggests that abandonments or declines cannot be explained primarily by a restructuring of the regional road network.

However, we must be cautious regarding the Late Roman period, which should be studied using a wider range of settlements to fully perceive the evolution of the network of exchange. Indeed, the end of monumental architecture and euergetism makes the major places of this period much less easy to apprehend from archaeological data than for the previous periods, which are far better served by epigraphy and evidence of religious activity. The Late Antique central places are hence probably poorly represented in our modelling. Therefore, at this stage of the study, we will make only preliminary observations:

We observe that the modelled channels for this period tend to pass via the location of former aggregated settlements that were not used in the calculation. The configuration of the general pattern of agglomeration would induce movement through (or close by) these sites anyway. The case of Ambrussum has already been discussed above: the road station is the only remaining settlement in the period studied, despite the fact that the place seems still to be well located in the regional path network; nevertheless its regional role may have 
been transferred to Lunel-Viel. The case of Mauressip is very interesting insofar as it seems to illustrate a process of the survival of some roads near abandoned sites: when new settlements are established along a pre-existing network (Nages and Plaisance in this case), they continue to maintain the structure of the road network, even if the original places are no longer active. Note that in the model A the perpetuation of the east-west road near the former oppidum (road L) seems due only to the existence of the Late Roman settlements (Puech des Mourgues and St-Julian); this raises the question of whether there was a process of reactivation of this track during the late Roman Empire.

\section{Conclusion}

The simulation of communication channels in this study was performed using several models. In addition to the use of common commercial GIS software, a procedure for calculating least cost paths has been proposed. In addition, the impact of a perceptual factor has been tested (the field of view).

The analysis of these models - from comparison with the presumed Roman roads, and consistency with the entire settlement pattern at different times - led us to consider the coexistence of two types of networks: a network of pathways relatively uninfluenced by the topography and rather straight, which favours the transition into the lowlands, and a network which integrates the visual factor, which favours elevated places. This second type of modelled network seems to have a separate function from the first: it does not just reproduce a different way of moving but also tends to serve a specific category of sites, namely those of very short duration.

The two types of road network model can give new perspectives on the changing pattern of agglomerations. They show a slow construction of the road network from the Iron Age up to the early Roman period (Ist century AD). Oppida of the second Iron Age and small towns created at the beginning of the Roman period fit into the networks modelled for previous periods: settled in the vicinity of previous communication channels, these agglomerations seem to benefit from pre-established communication structures. In this sense, the new major settlements did not really change the structure but completed it. Nevertheless, the models suggest that each introduction of new major settlements created or reinforced certain roads, or sections of roads, which offered alternatives to the old towns. Also, it is open to question whether these new agglomerations had the effect of channelling some of the alternative paths or weakening the position of the older towns in the communication network. This approach puts a different perspective on old questions about the evolution of the network of regional centres, driven by opposing logics of integration and competition.

For the late Roman Empire, however, the possible impact of the changes in the settlement pattern - characterized by the decline of several originally indigenous towns - on the 
organization of the communication network are poorly identified by the modelling of recognized towns.

The confrontation between the road network models and the roads considered to be Roman has provided more questions than answers. At this stage of research on communication networks, the modelled results give a glimpse into a phenomenon of integration between different status of roads. The regional road network modelling shows that some inter-regional roads are likely formed by connecting up regional routes. In addition, some anomalies suggest that tracks could have swung between the attraction of long-distance networks and the logic of local communications, and could well have had a story much more dynamic than is indicated by the historical regression analysis of the road network. The intermediate level of the communication network (supra-local) - incorporating the role of large rural settlements - should be taken into account in order to test this hypothesis.

\section{Acknowledgements}

The authors wish to thank especially Laure Nuninger (UMR 6249, CNRS, France), Tomaž Podobnikar (Institute of Anthropological and Spatial Studies, ZRC SAZU, Slovenia) for their participation in the research on ancient path modelling and Krištof Oštir (Institute of Anthropological and Spatial Studies, ZRC SAZU, Slovenia), Takeshi Shirabe (Institute for Geoinformation and Cartography, TU Vienna, Austria) for their suggestions during the development of the algorithm. The proposed least cost path modelling procedure was developed through a collaborative interdisciplinary project initiated in a research programme between France and Slovenia (Proteus programme 2004-2005) and pursued within the ModeLTER (institute founded by ZRC SAZU and CNRS: 2007-20I0).

\section{References}

Bertoncello, F. / Fovet, E. / Gandini, C. / Trément, F. / Nuninger, L. (2012)

"Spatio-temporal Dynamics of Settlement Patterns from 800 BC to $800 \mathrm{AD}$ in Central and Southern Gaul: Models for an Interregional Comparison over the Long Term", in: C. Gandini / F. Favory / L. Nuninger (eds.), ArchaeDyn: 7 Millennia of Territorial Dynamics. Settlement Pattern, Production and Trades from Neolithic to Middle Ages. Proceedings of the Final Conference of the ArchaeDyn Project, Dijon, 23-25 June 2008, Oxford, 5I-64.

Bonnaud, R. / Raynaud, C. (1994)

Rapport de prospection systématique $n^{\circ}$ 2. Moyenne vallée du Vidourle, communes de Combas, Fontanès et Souvignargues (Gard). Rapport de prospection pédestre, programme de prospection-inventaire "Vaunage Vidourlenque et Vistrenque" (I994-I998), Contribution à la carte archéologique du Languedoc oriental, SRA Languedoc-Roussillon, inédit. 
Castellvi, G. / Comps, J.-P. / Kotarba, J. / Pezin, A. (eds.) (1997)

Voies romaines du Rhône à l'Èbre: Via Domitia et Via Augusta, Paris.

Charvet, G. (1873)

"Les voies vicinales gallo-romaines chez les Volques Arécomiques", in: Bulletin de la société scientifique et littéraire d'Alès V, 8I-II5 and I58-248.

Clément, P.-A. (2003)

Les chemins à travers les âges en Cévennes et bas Languedoc, Montpellier. First published I983.

Clément, P.-A. / Peyre, A. (I99I)

La Voie Domitienne. De la via Domitia aux routes de l'an 2000, Montpellier.

\section{Columella}

De re rustica. Trans. H. B. Ash (I94I), London.

De Silva, M. / Pizziolo, G. (200I)

"Setting up a 'Human Calibrated' Anisotropic Cost Surface for Archaeological Landscape Investigation”, in: Z. Stančič / T. Veljanovski (eds.), Computing Archaeology for Understanding the Past. Proceedings of the 28th Computer Applications and Quantitative Methods in Archaeology Conference, Ljubljana (Slovenia), I8-2I April 2000, Oxford, 279-286.

Durand-Dastes, F. / Favory, F. / Fiches, J.-L. / Mathian, H. / Pumain, D. / Raynaud, C. / Sanders, L. / Van der Leeuw, S. (eds.) (1998)

Des oppida aux métropoles. Archéologues et géographes en vallée du Rhône, Paris.

\section{ESRI (2009)}

Esri - ArcGIS Desktop 9.3 Help: Spatial Analyst. http://webhelp.esri.com/arcgisdesktop/ 9.3/index.cfm?topicname=how\%20pathdistance\%20works\& (seen I7. 9. 20I0).

Favory, F. / Fiches, J. L. / Raynaud, C. (1985)

"Occupation du sol entre Lez et Vidourle: approche des structures agraires dans la plaine littorale à l'époque romaine", in: Etudes languedociennes. Actes du IIo $\mathrm{e}^{\mathrm{e}}$ congrès national des sociétés savantes, Montpellier, I985, Paris, I6I-I79.

Favory, F. / Girardot, J.-J. / Raynaud, C. / Roger, K. (I994a)

"L'habitat gallo-romain autour de l'étang de l'Or (Hérault). Hiérarchie, dynamique et réseaux du II ${ }^{\mathrm{e}}$ s. av. au Ve ap. J.-C.”, in: Mélanges Pierre Lévêque 8, I23-2I5.

Favory, F. / Parodi, A. / Poupet, P. / Raynaud, C. (1994b)

"Lunel-Viel et son territoire", in: F. Favory / J.-L. Fiches (eds.), Les campagnes de la France méditerranéenne dans l'Antiquité et le haut Moyen Age, Paris, I63-245.

Fiches, J.-L. (1985)

"Remarques sur le réseau antique dans la région de Nîmes", in: Les routes du Sud de la France, de l'Antiquité à l'époque contemporaine. Colloque du Comité des Travaux Historiques et Scientifiques I, I35-I43.

Fiches, J.-L. (1997)

"Le relais d'Ambrussum, de l'oppidum au Puech des Mourgues", in: G. Castellvi, / J.-P. Comps / J. Kotarba / A. Pezin (eds.), Voies romaines du Rhône à l'Èbre: Via Domitia et Via Augusta, Paris, 6o-68. 
Fiches, J.-L. (ed.) (2002)

Les agglomérations gallo-romaines en Languedoc-Roussillon. Publication du Projet Collectif de Recherche (1993-I999), Lattes.

Herzog, I. (2013)

"Theory and Practice of Cost Functions", in: F. Contreras / M. Farjas / F. J. Meleros (eds.), Fusion of Cultures. Proceedings of the 38th CAA Conference, Granada (Spain), April 2010, Oxford, 43I-434.

Kokalj, Ž. / Zakšek, K. / Oštir, K (20II)

"Application of Sky-view Factor for the Visualization of Historic Landscape Features in Lidarderived Relief Models", in: Antiquity 85, 263-273.

Laforgue, J. / G. Castellvi / J.-P. Comps (1997)

"Le tracé général", in: G. Castellvi, / J.-P. Comps / J. Kotarba / A. Pezin (eds.), Voies romaines du Rhône à l'Èbre: Via Domitia et Via Augusta, Paris, 23-36.

Lee, J. / Stucky, D. (1998)

"On Applying Viewshed Analysis for Determining Least-cost Paths on Digital Elevation Models", in: International Journal of Geographical Information Science I2(8), 89I-905.

Llobera, M. (2000)

"Understanding Movement: A Pilot Model towards the Sociology of Movement", in: G. Lock (ed.), Beyond the Map. Archaeology and Spatial Technologies, Amsterdam, 65-84.

Lu, M. / Zhang, J. F. / Lv, P. / Fan, Z. H. (2008)

"Least Visible Path Analysis in Raster Terrain", in: International Journal of Geographical Information Science 6(22), 645-656.

Minetti, A. / Moia, C. / Roi, G. / Susta, D. / Ferretti, G. (2002)

"Energy Cost of Walking and Running at Extreme Uphill and Downhill Slopes", in: Journal of Applied Physiology 93(3), I039-1046.

Monteil, M. (1999)

Nîmes antique et sa proche campagne, Lattes.

Nuninger, L. (2002)

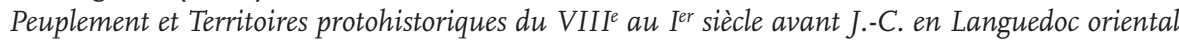
(Gard-Hérault), doctoral thesis in Archéologie, 2 vol., Université de Franche-Comté, Besançon. http://tel.archives-ouvertes.fr/docs/00/04/54/06/PDF/telooo0298I.Ithese.pdf.

Ouriachi, M.-J. (2009)

Habitat, terroirs et territoire en Languedoc oriental durant l'antiquité. Approche spatio-temporelle d'un système de peuplement, doctoral thesis in Histoire, 2 vol., Université de Franche-Comté, Besançon.

Parodi, A. / Raynaud, C. / Roger, J.-M. (I987)

"La Vaunage du III siècle au milieu du XII ${ }^{\mathrm{e}}$ siècle. Habitat et occupation des sols", in: Archéologie du Midi Médiéval 5, 3-59. 
Podobnikar, T. / Hvala, S. / Dular, J. (2004)

"Iterative Approach to Ancient Paths Modelling in the Iron Age Study of the Dolenjska Region (Slovenia)", in: K. Ausserer / W. Börner / M. Goriany / L. Karlhuber-Vöckl (eds.), Enter the Past: The E-way into the Four Dimensions of Cultural Heritage. Proceedings of the 3oth Computer Applications and Quantitative Methods in Archaeology Conference, Vienna (Austria), April 2003. Oxford.

Provost, M. / Dedet, B. / Fabre, G. / Pène, J.-M. / Petitot, H. / Raynaud, C. / Roger, K. / Vidal, L. (eds.) (1999)

Le Gard. Carte archéologique de la Gaule, 30/2-3, Paris.

Py, M. (1990)

Culture, économie et société protohistoriques dans la région nîmoise, 2 vol., Rome.

Py, M. / Vignaud, A. (1998)

"Voie et habitat protohistoriques de Peyrouse à Marguerittes (Gard) (V $\mathrm{V}^{\mathrm{e}}$ siècle avant notre ère)", in: Document d'archéologie méridionale 2I, I8I-I96.

Raynaud, C. (1990)

Le village gallo-romain et médiéval de Lunel-Viel, la fouille du quartier ouest (Annales littéraires de l’Université de Besançon), Paris.

Raynaud, C. (2002)

chapters "Mauressip, Saint-Côme-et-Maruéjols", "Nages, Nages-et-Solorgues", "Plaisance, Calvisson" and "Varatunnum (Saint-Julien), Salinelles", in: Fiches, J.-L. (ed.) (2002), Les agglomérations gallo-romaines en Languedoc-Roussillon. Publication du Projet Collectif de Recherche (I993-1999), Lattes, 595-36r and 65I-655.

Raynaud, C. (2007)

Archéologie d'un village languedocien, Lunel-Viel (Hérault), du I ${ }^{e r}$ au XVIII siècle, Lattes.

Van Leusen, M. (1999)

"Viewshed and Cost Surface Analysis using GIS", in: J. Barceló / I. Briz / A. Vila (eds.), New Techniques for Old Times. Proceedings of the 26th Computer Applications and Quantitative Methods in Archaeology Conference, Barcelona, March 1998. Oxford.

Van Leusen, M. (2002)

Pattern to Process: Methodological Investigations into the Formation and Interpretation of Spatial Patterns in Archaeological Landscapes, doctoral thesis, 2 vol., Rijksuniversiteit Groningen, Groningen. http://dissertations.ub.rug.nl/faculties/arts/2002/p.m.van.leusen/.

Verhagen, P. / Gili, S. / Micó, R. / Risch, R. (1999)

"Modelling Prehistoric Land Use Distribution in the Rio Aguas Valley (SE Spain)", in: L. Dingwall / S. Exon / V. Gaffney / S. Laflin / M. Van Leusen (eds.), Archaeology in the Age of the Internet. Proceedings of the 25th Computer Applications and Quantitative Methods in Archaeology Conference, Birmingham, April I997. Oxford.

Vial, J. (ed.) (2003)

Le Montpelliérais. Carte Archéologique de la Gaule 34/3, Paris. 
Vion, E. (1989)

"L'analyse archéologique des réseaux routiers: une rupture méthodologique, des réponses nouvelles", in: Paysages découverts I, 67-99.

Wheatley, D. / Gillings, M. (2002)

Spatial Technology and Archaeology, the Archaeological Applications of GIS, New York.

Yokoyama, R. / Shirasawa, M. / Pike, R.J. (2002)

"Visualizing Topography by Openness: A New Application of Image Processing to Digital Elevation Models", Photogrammetric Engineering \& Remote Sensing 68, 251-266.

Zakšek, K. / Oštir, K. / Kokalj, Ž. (20II)

"Sky-View Factor as a Relief Visualization Technique", Remote Sensing 3(2), 398-4I5. 



\section{Philip Verhagen*, Silvia Polla***, lan Frommer****}

\section{Finding Byzantine junctions with Steiner trees}

\section{Introduction}

In archaeology, computational approaches to the study of movement practices have become more and more popular in recent years, especially when applied to prehistoric contexts (Bell / Lock 2000; Llobera 2000; De Silva / Pizziolo 200I; van Leusen 2002; Fábrega Álvarez / Parcero Oubiña 2007; Snead et al. 2009; Llobera et al. 20II). The main aim of these methods is not just to reconstruct paths and road systems, but to use these models to understand the establishment and transformation of a hierarchical network of settlement nodes, also including a focus on off-site land use practices.

In this paper, we will introduce an example of the use of GIS-based modelling techniques for the study of the Roman-Byzantine communication system in the Roman Province of Cappadocia, in modern Turkey. We will argue that adopting a landscape archaeology approach to the analysis of an historic road system contributes to a deeper understanding of settlement dynamics (Bell et al. 2002). A GIS-based, spatial approach allows us to study settlements and pathways in a more formal manner and, by doing so, to address questions about ancient cognitive geography and past decision-making processes (Rockman ( Steele 2003). By systematically analysing the structure and phenomenology of the Roman provincial landscape, indicators of power and social order can be extracted from agricultural centuriation and communication systems (Witcher I998; Laurence I999). In the cultural context of Roman and Byzantine communication systems, GIS methods are usually employed to reconstruct ancient routes in the landscape. These reconstructions are constrained by the possibilities of testing the model with material evidence of roads (remains, milestones, bridges; see Graßhoff / Mittenhuber 2009). A further limitation concerns the integration of path models created at a micro-regional scale with a macro-regional approach that considers the road system as a coherent planned network of connections.

We therefore aim here to combine path models constructed on the basis of topographic and environmental constraints at the micro-regional level - like slope, distance to natural resources, and visibility - with a model of macro-regional movement in a strategic network composed of nodes and junctions. In this network, movement is structured and affected by "cultural" constraints, like site density and distribution, and the position of strategic administrative, economic, religious and/or military centres.

\footnotetext{
* Vrije Universiteit Amsterdam.

$* *$ Freie Universität Berlin.

*** US Coast Guard Academy.
} 
The integration of these two approaches is realized by combining a GIS approach for modelling segments of the system (paths), based on the environmental context, with a Steiner tree vector-based approach that takes into account the nodes and edges of the system. As an example, we use the documented inter-regional road system of Cappadocia that was established in the Roman period. It follows the previous pattern of macro- (Persian Royal Road) ${ }^{\mathrm{I}}$ and micro-regional (tribal villages) movement axes (Mitford 2000). Written sources and archaeological remains document this pattern of communication routes, consisting of strategic connections along a set of way stations. It can still be recognized in the pattern of Seljuk caravanserais in historical times (Hild I977).

\section{The Roman and Byzantine road system in Cappadocia}

For this case study we focus on the methodological aspects of reconstructing and analysing the inter-regional road system of the Roman/Byzantine province of Cappadocia in Asia Minor (current Kapadokya in Turkey). The road system of Roman/Byzantine Cappadocia is an inter-regional communication system, from which we will analyse only one segment and we will focus on path modelling at the micro-regional scale. For this, we will integrate path modelling and network modelling approaches, and take into account topography-based constraints (Llobera 2000; 200I), as well as the structure of the macro-regional network.

The study region (Fig. I) is dominated by mountains and characterized by a continental climate with snow from November to April in the area above the tree line. The area studied is a high plateau, enclosed to the south by the Taurus mountain range and cut transversely by the Antitaurus massif. The regional settlement pattern and the road system of Cappadocia are strongly structured and defined by topography. From the Bronze Age onward, the river plains were the main areas of settlement and acted as the primary axes of communication. Assyrians, Hittites, Phrygians, Lydians and Persians successively occupied the territory of Cappadocia, and were later followed by Seleucid, Roman, Byzantine, Seljuk and Ottoman rulers. The region has been subject to a centralized administration since the Persian period, and this clearly influenced the strategic construction and longterm use of the road systems. A strong relationship is evident, for example, between the Roman road system and the Seljuk caravanserais.

During the Roman Empire, strategic routes were set up from the provincial capital of Caesarea (currently Kayseri; Greek: Kaisarea) to connect it to Melitene (currently Malatya), over a total distance of approximately $250 \mathrm{~km} .{ }^{2}$ Caesarea, the starting point, was a central

I Herodotus 5.52-54; French (I998). On the Cappadocian pathways cf. Herodotus 52.2.2, French (I998, I8) and Hild (I977, 99 and Abb. 68) on the route from Elbistan to Melitene. For a localization of the route on modern topography cf. French (I998, 28: Kayseri sheet: Kayseri-(Aydinlar)-Kamber-Akmescit).

2 The modern road connection measures $339 \mathrm{~km}$. 


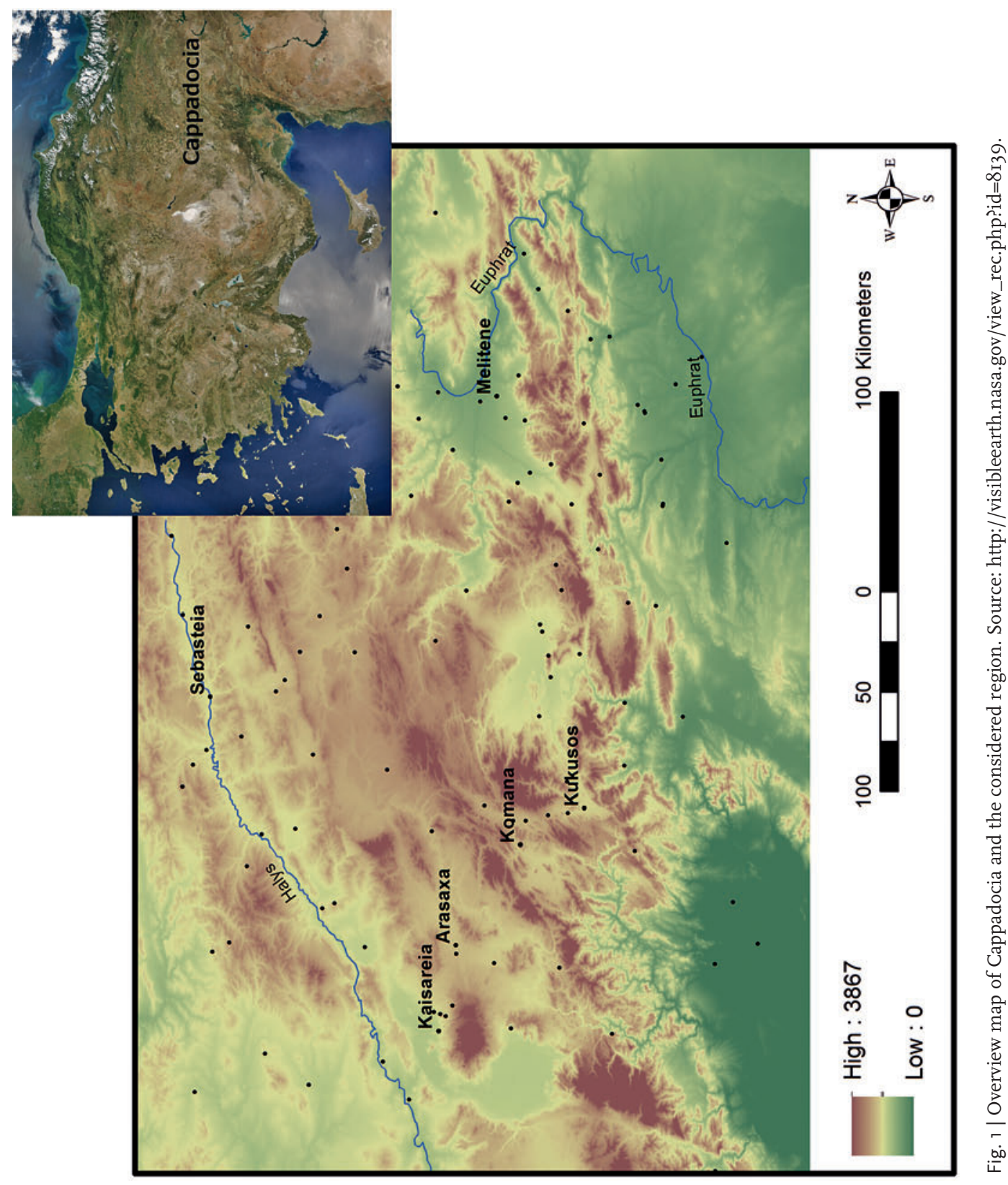


place from Assyrian times. It became a Hellenistic polis and then capital of the Roman province of Cappadocia and it was a central node of the road system in central Asia Minor during both Roman and Byzantine times. The connection we are studying was the southern alternative to reach Melitene, via Comana (Caesarea - Arasaxa - Comana - Kokousos Melitene; Hild I977, 85; Mitford 2000, 99I). Along the route, way stations were built at distances of approximately $40 \mathrm{~km}$. A number of milestones, some of them found in situ, are attested along the route to Comana (Hild I977, 85; French I988 and 20I2), and trace the corridor used by the Roman road. The so-called Roman Itineraria list the distances between the stations along the roads. For this area, the Itinerarium Antonini (ItAnt) and the Tabula Peutingeriana (TabPeut) provide geographical information about the paths used.

The pathway to Melitene passing by Comana seems to have been in use only until the Early Byzantine period (4th - 7th century AD; Hild I977, 84). In the $7^{\text {th }}$ century, an alternative northern route passed via the fortress of Taranta to Melitene (for documentation and sources see Hild I977, 84 n. 73). According to the sources, the area of the Antitaurus mountains, made desolate by the Byzantine campaigns against the Arabs, was re-organized during the 8th century. The eastern frontiers of the Byzantine Empire were restructured and the road system changed. In the Middle Byzantine period (9th - IIth century AD) a new alternative route diverged from Arasaxa - the first node of the Roman road and maintained as a Byzantine junction - to the north, passing via Tzamandos and Ariaratheia to Arabissos (as documented by Arab itinerary sources: Hild I977, 90 and n. I08). This last connection is an alternative route that passes via Arabissos. Arasaxa still seems to have been used as a way station during the Mamluk campaign against Caesarea in I277. The northern variant via Taranta was re-established in the Seljuk period and still serves today as the main route from Kayseri to Malatya (Hild I977, 84, note 75). The southern variant is no longer used for modern traffic (Hild i977, 88).

\section{Case study}

For this paper, we only consider the first stretch of the route, from Caesarea to Arasaxa, the first way station on the route listed in the ItAnt. It was still in use as a caravanserai in Ottoman times. The straight-line distance between these sites is $34.87 \mathrm{~km}$. In order to reach Arasaxa from Caesarea, the route has to move uphill and pass between the high Argaeos mountain to the south, ${ }^{3}$ and a lower mountain range to the north. On this stretch, the road has to cross several river valleys that are dry most of the year. As far as we know, no other settlements were connected by the road in Roman times.4 In Byzantine times, however,

3 The extinct volcano of Erciyes Dağı, the highest mountain in central Anatolia, with its summit reaching 4 OI3 $\mathrm{m}$.

4 The TabPeut links Caesarea first to Sinispora (?) $(35.52 \mathrm{~km}$ ) and then to Arasaxa (I9.24 km; cf. Mitford 2000 , 990). The name Sinispora is corrupt, however (it mixes two other toponyms), and should be eliminated (Ramsey 2010 [1890], 272). For an approach comparing Itinerary sources to reconstructed roads see French (I974). 


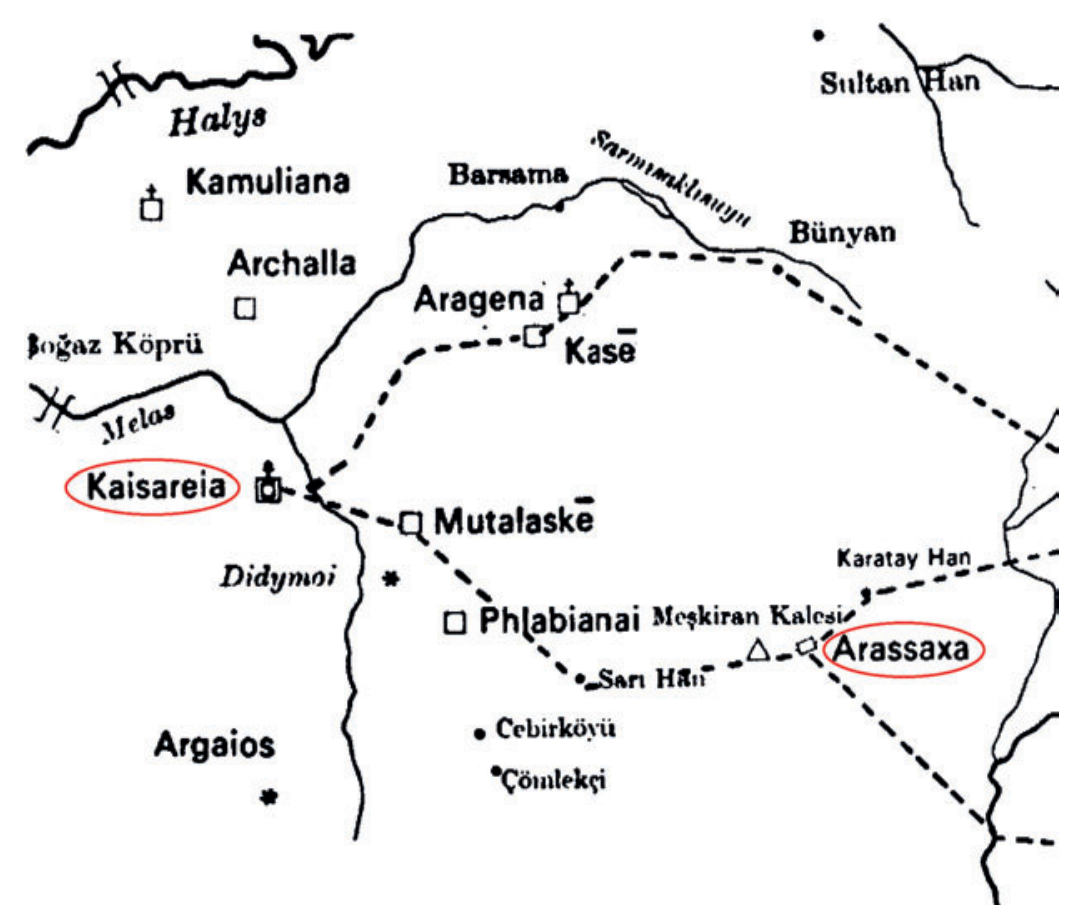

Fig. 2 | Reconstruction of the stretch between Caesarea and Arasaxa (Hild I977, map 6).

a new military and religious settlement pattern developed along the road and probably redefined it.

The reconstruction of the stretch by Hild (I977, 85 and map 6; Fig. 2) shows a route that passes through the sites of Moutalaske (currently Talas; a Byzantine 6th - I3th century hermitage site with religious buildings), Sari Han (a Seljuk caravanserai dating from the I3th century, partly built from Byzantine spolia) and Meşkiran Kalesi (currently Meskuan; a Byzantine castle). The sites of Iskokson (a small Byzantine site with a church) and Sakaltutan (a possible Byzantine castle where a Roman milestone was found, not in situ) are indicated as additional waypoints (Hild I977, map 6). About $4 \mathrm{~km}$ west of Sakaltutan, the route passes north of the excavated rock-cut monastic complex at Kepez (Hild / Restle I98I, map; Decker 2007, 242). Obviously, these are all post-Roman sites, and the reconstruction is therefore only pertinent for the Byzantine period. 5 The sources attest to the changing pattern of communication routes in this region. The Byzantine and Medieval phases show a restructuring of the road from Caesarea to Arasaxa along a new settlement pattern constituted by religious (Moutalaske is a birthplace of saints) and military landmarks (Sari Han is a caravanserai; Meşkiran Kalesi a Medieval fortress).

5 According to Hild / Restle I98I the settlements in this area date from the $4^{\text {th }}$ - I3th centuries AD. 
The existing information about the diachronic settlement pattern, roads and communication system in this macro-region offers a convenient dataset for exploratory purposes. However, no comprehensive archaeological survey at the micro-regional scale has been undertaken across eastern Cappadocia. ${ }^{6}$ Only some isolated surveys have been done, focusing on churches and Byzantine paintings, and almost all physical remains from the ancient world have been destroyed or re-used. Apart from the displaced Roman milestone at Sakaltutan, the only known traces of the Byzantine road have been discovered near Meşkiran Kalesi (Hild I977, 85). Modern travel journals from the I9th century (see Mitford 2000, 985-986) provide some additional descriptions locating places and roads (Ramsey 2010 [1890]). However, these are not always reliable.

In order to analyse the course of the paths, and their stability or possible change over time in relation to the documented pattern of settlements, we have used the following dataset including topography, historical geography, archaeological and epigraphic sources:

- $\quad$ Digital elevation model: Aster DEM at $30 \mathrm{~m}$ resolution;

- GUGK (Glawnoe Uprawlenie Geodesii i Kartografi) Maps (scale I : 200,000)

- $\quad$ Sites, bridges, road remains:

- Google Earth-based localizations of ancient sites on the basis of the modern names;

- Hild / Restle (I98I);

- Milestones: French (I988, 2012);

- $\quad$ Road system description: Hild (I977);

- General information: Map 64 Caesarea-Melitene (Mitford 2000) in the Barrington Atlas of the Greek and Roman World (Talbert 2000).

- Itinerary Sources:

- Itinerarium Antonini (Cuntz I990);

- Tabula Peutingeriana (Miller ig88).

The ancient geographical dataset of the Roman Itineraria contains explicit information about settlements and distances as well as implicit information about the regional road network as a coherent infrastructure, connecting central places and a pattern of secondary settlements or stations. Archaeological information about the nature and typology of the secondary settlements related to the road system is not available for the region. Stations indicated in the Itinerary sources cannot always be located on the ground.

\section{Roman road building and least cost path modelling}

In the current case study we are dealing with the construction and maintenance of the roads that were administered by the Roman and Byzantine Empire. The archetypical

6 For an archaeological survey focusing on roads and paths in Cappadocia in the Sivas region, see Tuba Ökse (2007). 
image of a Roman road is that of a straight route, paved with slabs of stone. The Roman administration indeed placed special emphasis on the efficiency of connections. The emperor Vespasian, for example, when advancing into Galilee in AD 67, records that he straightened and levelled existing tracks (Hucker 2009). All over the Roman Empire we find evidence that the construction of the major roads was aimed at creating speedy and reliable connections that could also be easily maintained. Even though constructing a Roman road must have been an expensive venture, once the roads were built they proved to be highly persistent, as is witnessed all around the former Roman Empire, where many Roman routes are still in use. However, in many instances the landscape offered challenges to Roman engineers, like steep slopes or wet areas that made the construction of straight stretches difficult (Quilici I995). The Romans therefore adopted a flexible approach to road construction. Evidence for complex engineering solutions can be found in many places, in particular bridges, dikes and switchbacks, and sometimes even tunnels. All in all, the Roman road system is more variable than is often thought.

Where to put the roads must have been dictated by military, political and economic factors, for which the speed, reliability and comprehensiveness of the connections between administrative centres must have been of primary importance. Two aspects of Roman road building make it somewhat different in terms of route (least cost path) modelling than most other cases considered in archaeology. These are connected to the primarily military function of the roads. In fact, most major roads in the Roman provinces were initially built to accommodate the army advancing into enemy territory, and were only later fixed in place as "imperial highways." 7 The roads had to accommodate not just the soldiers and horses, but also the supply trains of wagons and carts. ${ }^{8}$

From a modelling perspective, this poses a challenge: while extensive (experimental) research has been done to define equations that adequately model speed and energy expenditure for travel on foot (see e.g. Herzog 2013), similar data are not available for wheeled transport using transport animals. One of the few authors who has made an effort to collect this information is Raepsaet (2002). He produced an equation that gives the traction force needed to get a cart moving, depending on the weight of the cart, the paving used, and the slope. 9 If we use this equation with the figures for a typical Roman cart, the carpentum,

7 On the organization and infrastructure of the cursus publicus see Kolb (2000).

8 For a short introduction to Roman land transport based on literary, epigraphic and legal sources see Meijer / van Nijf (I992, I36-I40).

$9 \quad \mathrm{~T}=\mathrm{kP}+\mathrm{Pi}$

where

$\mathrm{T}=$ traction force needed for movement

$\mathrm{P}=$ weight of loaded cart in $\mathrm{kg}$

$\mathrm{k}=$ rolling coefficient

$\mathrm{i}=$ slope in $\mathrm{m} / \mathrm{m}$

The rolling coefficient $\mathrm{k}$ is composed of a pavement friction factor and an axle friction factor. 

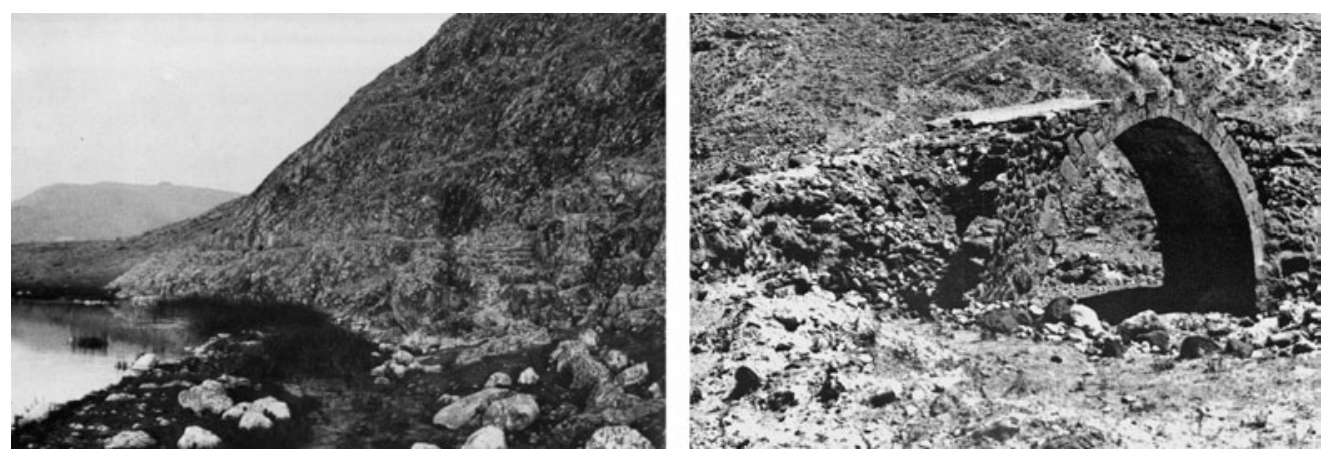

Fig. 3 | Ancient road remains in Cappadocia (Hild I977, Abb. 62: road remains west of Elbistan;

Abb. 68: Byzantine bridge west of Akçadağ).

drawn by 2 mules with a supposed maximum load of $500 \mathrm{~kg}$ (Roth I998, 208-2I2), it indicates that it would be impossible to get these carts moving up a slope of more than $9 \%$. While we can assume that in the case of steeper slopes wagonloads would be reduced, most Roman roads never take slopes > I5\% (Hucker 2009; Quilici I995). "Normal" least cost path calculations using hiking functions, like those defined by Tobler (I993) or Minetti et al. (2002) are therefore not best suited for Roman road modelling.

Secondly, the positioning of Roman roads in various parts of the empire seems to indicate that visibility was an important consideration as well. In Britain for example, Roman roads consistently follow ridges and plateaus instead of valleys when given the choice (Hucker 2009). This may only partly have been for reasons of preventing ambush: when setting out the road, Roman engineers (gromatici) would have had to set up survey stations and sighting points on the route that should be intervisible. Typical distances between survey points would be in the order of $2-3 \mathrm{~km}$, but if braziers were used longer distances could be measured as well (Hucker 2009). The Roman road system in our study area was probably constructed in the same way.

Much less is known about the construction and maintenance of the Byzantine road system. The major waypoints were still maintained as traffic nodes, but instead of emphasizing speedy connections between the major administrative centres, the Byzantine road system constitutes a more fine-grained transport network that also connected the minor religious and military centres in the area. In eastern Cappadocia we have several archaeological remains that relate to the Byzantine road system (Hild I977; Hild / Restle I98I): in the area of interest a bridge on the road from Kayseri to Malatya is documented (Hild 1977, Abb. 68). From the material remains it is also clear that difficult topography was sometimes preferred over wetlands (Hild I977, 95 and Abb. 62, 68; Fig. 3). 


\section{Modelling the Roman route with least cost paths}

Because of the lack of applicable cost functions that take into account wheeled transport, we have compared the two most commonly used hiking functions (Tobler's and Minetti's) and a least cost function avoiding all slopes over $9 \%$ (which might have been prohibitive for wheeled transport). We have calculated least cost paths between Caesarea and Arasaxa based on these functions using a slope map derived from the Aster DEM. ${ }^{\text {Io }}$ The modelled paths between Caesarea and Arasaxa all show similar routes, passing north of all the Byzantine sites mentioned as waypoints by Hild (Fig. 4). The distance of the Tobler and Minetti paths is 37.26 and $37.5 \mathrm{~km}$ respectively, and both routes are relatively straight, with a sinuosity ${ }^{\mathrm{II}}$ of 1.07 and I.08 respectively. According to the ItAnt (Cuntz I990) and TabPeut (Miller i988), the length of the route from Caesarea to Arasaxa measures $35.52 \mathrm{~km}$ (24 Roman miles (mp); I mp = I.48 km (French I998, I46, fig. 2). The walking time needed to follow the shortest (Tobler) route is approximately 9 hours and I5 minutes, ${ }^{\mathrm{I} 2}$ and would therefore fit well within a day's travel. The route avoiding all steep slopes is $39.69 \mathrm{~km}$ long (sinuosity I.I4, approximately to hours walking).

These figures are in line with the available information on travel speeds in the Roman Empire. For pedestrian movement, Kolb (2000, 310, tab. I and note I; ibid. 3II) gives an average of $20-25 \mathrm{mp}(30-37 \mathrm{~km})$ per day. Similar figures are supplied for transport using pack animals like mules, donkeys, horses and in some regions even camels and dromedaries (on average $24 \mathrm{mp}$ or $35 \mathrm{~km}$ per day; Kolb 2000 , 3I2, tab. 2). Higher speeds could of course be achieved by riders on horseback or carts, especially with a regular change of animals.

The sources are less clear about travel speeds of heavy transport with wagons and carts. For ox-carts, a speed of $8 \mathrm{mp}$ (I2 km) per day is given by Kolb (2000, 316, Tab. 5). This, however, seems to be on the low end of the scale. For the Early Medieval period Bachrach (I993, 7I7) estimates a maximum speed of $9 \mathrm{mp}$ (I5 km) per day. Roth (I998, 2II), however, reports that igth-century American ox-carts could cover ig to $24 \mathrm{~km}$ (I2 to I5 $\mathrm{mp}$ ) per day. Mule-carts are faster and could easily cover is mp (30 km) per day (Bachrach I993, 7I7). Since there are no equations that specify the relationships between slope and travel speeds for various kinds of animals and carts, it is impossible to be more specific about the efficiency of the modelled paths with regard to the various modes of transport. In either case, it seems impossible for ox-carts to cover the whole distance between Caesarea and Arasaxa in one day, and even for mule carts it seems improbable.

Io The paths were calculated in ArcGIS 9.2, using the Path Distance module in order to account for the effect of anisotropic slope (see Herzog 2013).

II The sinuosity index (Mueller I968) is a measure of the directness of a route, it calculates the deviation from a straight line by dividing the route's length by the straight-line distance.

I2 The walking time calculations are based on Tobler's hiking equation. 


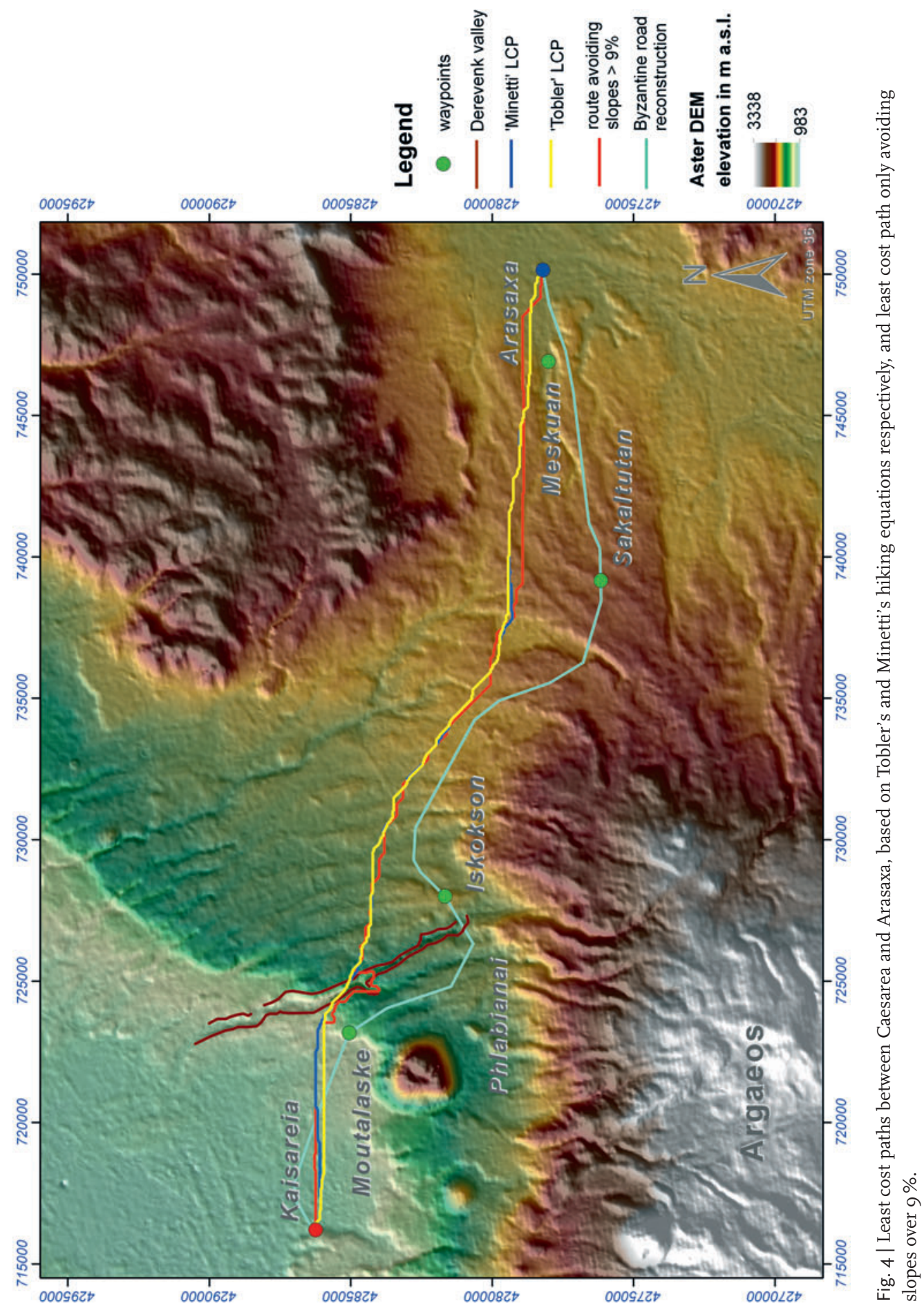




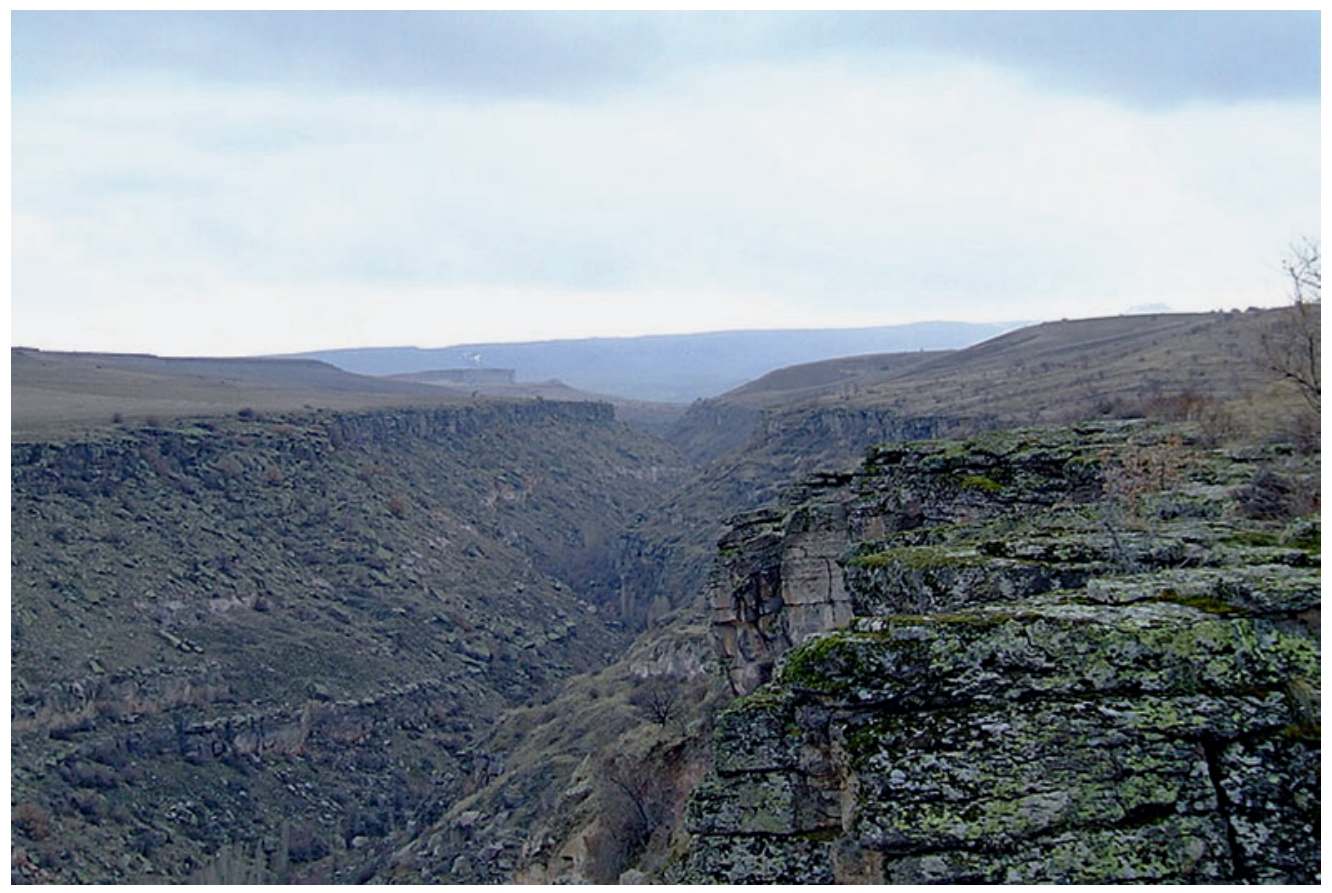

Fig. 5 | The Derevenk valley (http://static.panoramio.com/photos/original/20000398.jpg; copyright: Efkan Sinan).

The least cost path models do not adequately account for the crossing of the Derevenk valley, which has very steep sides (Fig. 5). The Aster DEM allows a relatively easy crossing just east of the site of Moutalaske, which seems a highly unlikely solution given the steep descent. The vertical accuracy and horizontal resolution of the DEM is probably not good enough to reflect the actual topography of the Derevenk valley. Obviously, by taking the route further up- or downstream, the building of an expensive bridge may have been avoided. Forcing the least cost path model to avoid crossing the Derevenk valley creates a more southerly variant (Fig. 6). However, it still does not pass through any of the sites mentioned by Hild. We can therefore conclude that Hild's reconstructed route, even when we force the least cost path to avoid the Derevenk valley, is not the most efficient option to reach Arasaxa from Caesarea. Hild's route has a length of $40.97 \mathrm{~km}$ (approx. II.5 hours walking, sinuosity I.I7).

This is also true when we take into account the Byzantine waypoints. Making the least cost path model pass through the Byzantine sites involves creating paths from site to site, rather than modelling a single route from Caesarea to Arasaxa. This results in a path with a total length of $39.17 \mathrm{~km}$ (approx. Io hours walking, sinuosity I.I2). Avoiding the Derevenk valley takes $40.39 \mathrm{~km}$ (approx. I0.25 hours walking, sinuosity I.I6). Following Hild's route 


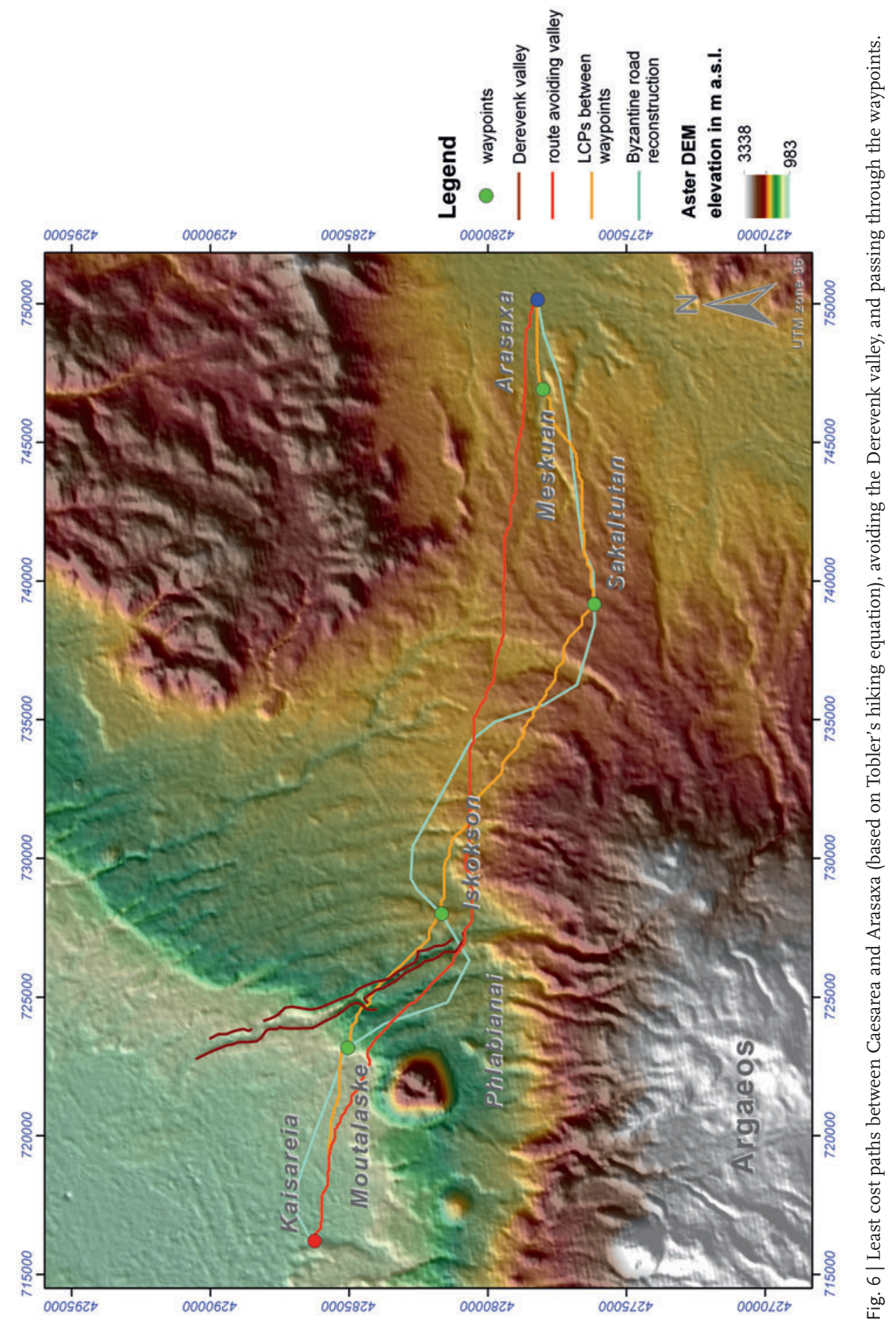


from Caesarea to Arasaxa would therefore add at least one hour extra walking. But since his reconstruction is plotted on $\mathrm{i}: 800,000$ scale topographic maps, it is probably not very accurate.

By comparing different sources we can conclude that the use of least cost path methods for road reconstruction conflicts with the unpredictability of past decision-making processes as a result of non-optimal environmental and/or cultural choices. However, we can gain a better understanding of these processes using a model based on formal criteria that involve quantitative and qualitative aspects related to environment and settlement history.

For example, if we include visibility into the model, by calculating a total viewshed of the area and letting this progressively weigh as a cost factor, the modelling results indicate that the routes with best visibility are found further to the north (Fig. 7). This suggests that Roman road building in the area was probably not dictated by optimal visibility. It also prompts the question if there was something like "good enough" visibility for the Roman gromatici, and whether using a total viewshed would be the best way to model this (see also Verhagen / Jeneson 2012).

\section{Junctions and Steiner trees}

Hild's reconstruction shows a junction that is located approximately halfway between the sites of Phlabianai (a Byzantine church site, $4^{\text {th }}$ - $13^{\text {th }}$ century AD) and Iskokson. Here, a second route branches off to the southeast, leading to the Byzantine settlements of Cebir and Tomarza and onwards to the Late Roman/Early Byzantine site of Kiskisos (Hild / Restle I98I, 206).

Additionally to slope, which influences the feasibility and stability of the paths, a structuring role in movement is played by nodes and junctions (Gibson 2007). Junctions are important elements in a coherent road system, but have been neglected in many case studies, in part because few applications of GIS in the field of Roman and Medieval archaeology are available (Witcher I998; Bell et al. 2002; Fiz/Orengo 2008; Bellavia 2006; Gaffney 2006; de Soto / Carreras 2008; de Soto 20I0). A GIS-based path modelling procedure using only archaeological sites as waypoints does not allow for the creation of junctions that optimize movement along the whole strategic network. From a mathematical point of view, the problem of finding the optimal interconnection of a set of points is covered by the Steiner Tree Problem, a generalization of the Minimal Spanning Tree Problem. Given a set of nodes (points) with edges (connecting lines) that connect various pairs of points and have associated costs, the minimal spanning tree seeks the least cost tree (i.e. a collection of edges having no loops, and the points they connect) containing each of the given points. In a Steiner Tree Problem, additional points (Steiner points) may be utilized if they can help lower the cost of the tree (Fig. 8). To avoid confusion, the original points that must be connected are 


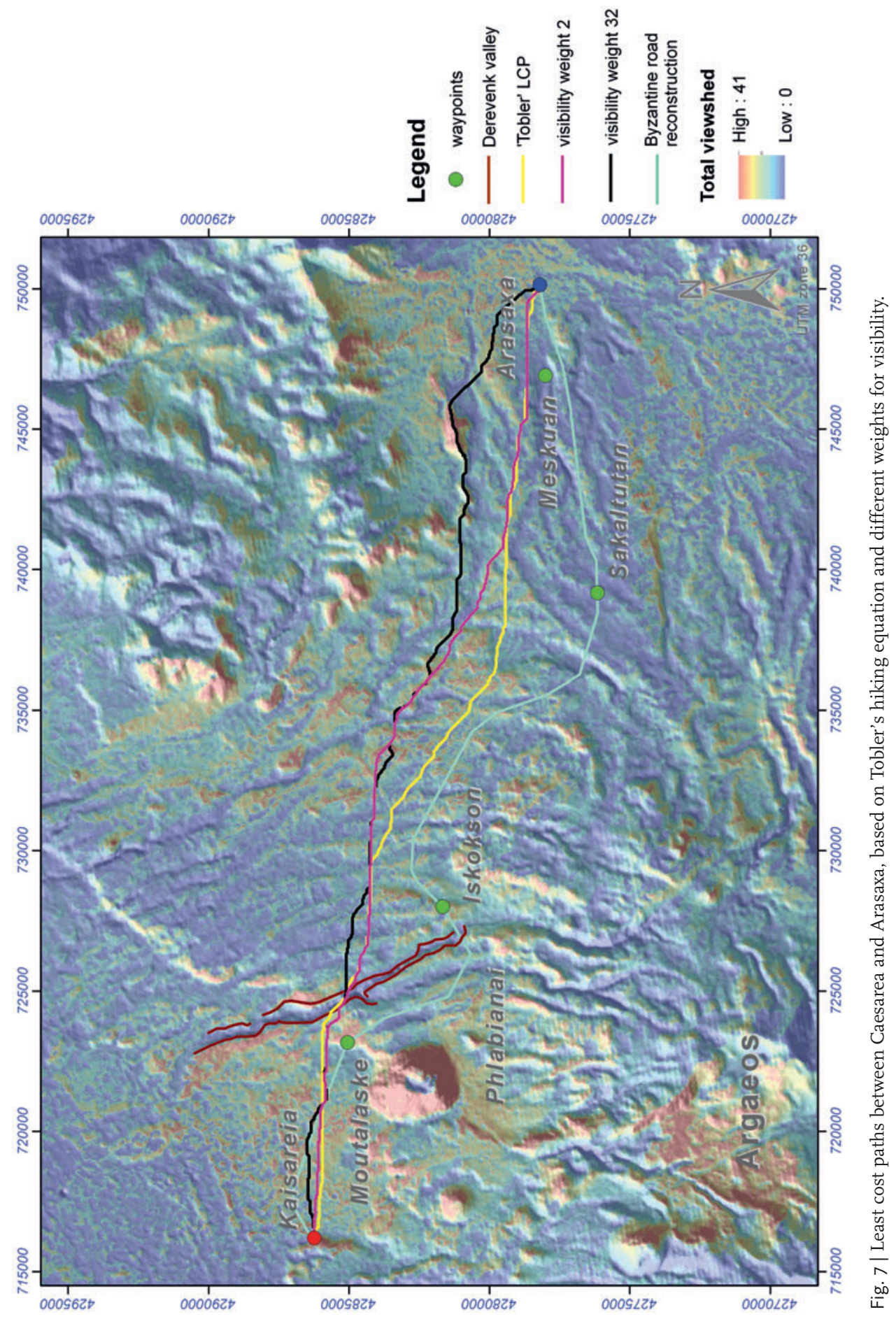


Fig. 8 Steiner tree connecting points $\mathrm{T}_{1}, \mathrm{~T}_{2}, \mathrm{~T}_{3}$, and $\mathrm{T}_{4}$ by using Steiner points $\mathrm{S}_{\mathrm{I}}$ and $\mathrm{S} 2$. The four terminal points could be connected without using Si and S2, but the cost (i.e., length of the tree in this case) would be higher.

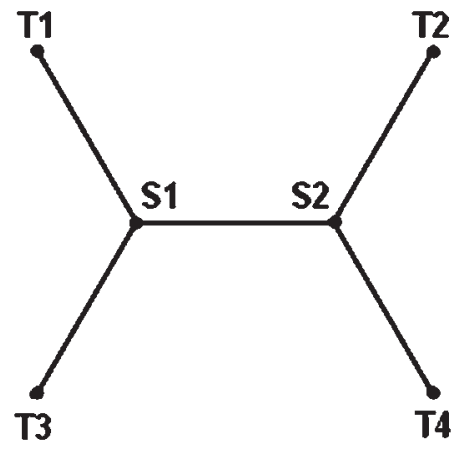

referred to as "terminal nodes." These problems are often situated in the Euclidean plane, in which case costs are the Euclidean distances. Since distances between settlements in real landscapes should not be measured as Euclidean distances, but as (non-uniform) cost distances, an additional complication is found in creating the optimal network connections. The Euclidean Non-Uniform Steiner Tree Problem, described by Frommer / Golden (2007a), aims to efficiently solve the Steiner Tree Problem for a network of points using non-uniform distances. In the Euclidean Non-Uniform Steiner Tree Problem, each location in the Euclidean plane has an associated cost. An edge connecting two points will have a cost that depends on the cost of the locations through which it passes (a least cost path). Devising a network of paths connecting sites in a rugged mountainous landscape can be formulated as a Euclidean Non-Uniform Steiner Tree Problem, with location costs dependent on land use, slope, elevation and other factors.

Along these lines, the problem of trying to find possible routes between archaeological sites given known waypoints can be formulated as a Euclidean Non-Uniform Steiner Tree Problem. The existing sites can be thought of as the terminal points in the tree that must be connected in a reconstruction of an ancient network of paths or roads. Steiner points help to lower the cost of the overall tree, i.e., they result in more efficient pathways. Furthermore, Steiner points always have at least three edges leading to/from them, and hence may function as junctions in a (road) network. Generating Steiner trees for larger sets of points is computationally intensive, however. Furthermore, no implementations of algorithms that generate Steiner trees from point data are available in GIS.13

I3 The v.net.steiner module in GRASS (grass.osgeo.org) only finds the optimal connection between a subset of points in an existing network (i.e. with predefined edges); it will not create a new network. 


\section{A genetic algorithm to solve the Euclidean non-uniform Steiner tree problem}

Frommer and Golden (2007a) developed a genetic algorithm to solve the Euclidean NonUniform Steiner Tree Problem, and applied this to sample problems with structured landscapes (e.g. hills, rings, etc.). The algorithm was later combined with GIS data in an exercise aimed at connecting recreational sites in Stowe, Vermont (Frommer / Golden 2007b). A weighted combination of layers of GIS data (elevation, land use and slope) was used to specify the underlying cost structure.

The problem is situated on a hexagonal grid. Each hexagonal cell on the grid may contain at most one point, and has a cost associated with it. Given two points, the edge connecting them is defined as the shortest path between them, which is not necessarily the straight line segment connecting the points. The cost of the edge equals the sum of the costs of the cells through which the edge passes plus one half the costs of the two end points' cells. Using a grid reduces the size of the solution search space from infinite to finite, though it is still potentially very large. It also allows the problem to be represented in network (or weighted graph) form. A genetic algorithm is only one possible solution, and some of the trade-offs between the genetic algorithm and other approaches are discussed in Frommer / Golden 2007a. What is important for this work is that the genetic algorithm finds good (and in some cases optimal) solutions for reasonably sized problems relatively quickly. It may not necessarily be the fastest or best performing algorithm, but it is quite flexible to changes in problem formulation.

Genetic algorithms are based on biological evolution and natural selection. They typically consist of a population of individuals representing solutions that change over time through the application of crossover and mutation operators. A fitness function assigns a value to each individual in the solution with regard to how well it meets the problem goal. In the genetic algorithm we employ, each individual in the genetic algorithm population is defined by a set of potential Steiner points. The fitness function is the cost of the minimal cost tree connecting the terminal points and possibly using some of the Steiner points. Lower cost solutions are chosen with higher probability than higher cost solutions, and are then used to generate new individuals through the use of crossover and mutation. This genetic algorithm is discussed more fully in Frommer / Golden $2007 \mathrm{a}$.

\section{Application}

The genetic algorithm was applied to find the minimal spanning tree that connects the waypoints on the route from Caesarea to Arasaxa and those on the route branching off to the southeast towards Cebir via Phlabianai, as specified by Hild (I977). The results are shown in Fig. 9. The genetic algorithm solution does an effective job of connecting the terminal points, while avoiding high cost regions wherever possible. The deviations from the Tobler 


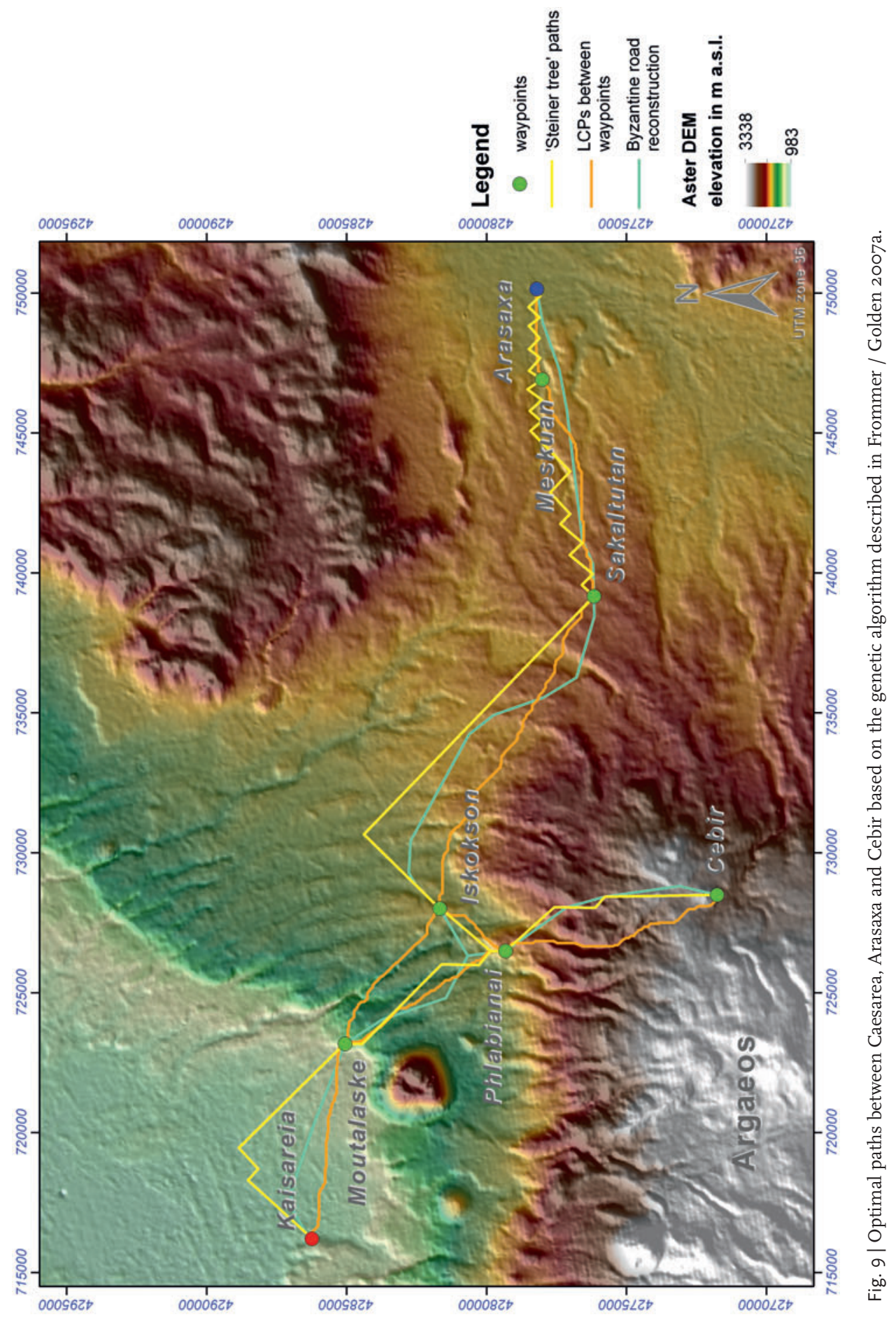


least cost paths calculated between the way points are clear. The two detours to the north (right from the start in Caesarea, and between Iskokson and Sakaltutan) are more in line with Hild's reconstruction than with the least cost path. The junction near Phlabianai is close to where Hild hypothesized it. Note that the genetic algorithm finds a detour in the upper left that is not found in the other models. This solution uses a narrow low-cost path of approach to Moutalaske that yields a cost approximately $3 \%$ less than the next best route. A question to consider is how likely people would be to find the less intuitive detour when it only provides relatively small savings. Such considerations can be incorporated in the algorithm, as described below.

Since the algorithm works on a hexagonal grid, the number of directions of edges is limited to six. So solutions sometimes exhibit staggered (zigzag) paths when they need to move in a direction other than one of the six. Because of this, the efficiency of the calculated route appears to be very low. The connection created between Caesarea and Arasaxa has a length of $50.84 \mathrm{~km}$ (approx. I3.5 hours walking, sinuosity I.46). The zigzags could be replaced by the lines they are attempting to follow in a post-processing routine. Given that this work represents only an initial exploration, the post-processing has not been implemented. Alternatively, the current set-up could be replaced with a rectilinear grid and edges allowed to take on any direction. Cost would be calculated using numerical line integrals. Steiner point locations would still need to be restricted, possibly to the centre of each cell. In addition, the grid could have multiple resolutions, with a finer grid used in areas of highly variable cost structure.

\section{Concluding remarks}

We have shown that the traditional application of least cost path algorithms will only calculate optimal pathways between pairs of points, and are not effective for finding intermediate waypoints, like those hypothesized in Hild's reconstruction of the Byzantine route between Caesarea and Arasaxa. The only way in which least cost paths will approach the location of the supposed route is by progressively including known waypoints and calculating least cost paths between them. Even then, the resulting path network will not be the optimal solution to connect a set of known points. It also deviates substantially from the route suggested by Hild. We applied the Euclidean Non-Uniform Steiner Tree Problem using the genetic algorithm developed by Frommer and Golden (2007a, 2007b) to the issue of finding the optimal connection between the waypoints on the route. This resulted in a modelled route network that, while not perfectly fitting the reconstruction, shares important characteristics with it, especially the presence of a junction outside the set of known points, as well as deviations from the least cost paths that are more in line with the reconstructed route. From this we can (cautiously) conclude that the Byzantine road system was constructed with the aim of creating optimal connections for the whole micro-regional network. This 
clearly contrasts with the system of macro-regional connections that characterizes the Roman road network as described by the itinerary sources. The results fit with what we already know about the Byzantine road system. The new religious ${ }^{\mathrm{I} 4}$ and military geography of the area restructured the micro-regional communication and transport network, using the Roman way stations as points of departure. Both the Byzantine settlement pattern and the modelled reconstructions suggest that the Roman road itself was not in use anymore.

As alluded to above, the actual paths used in the Byzantine period may not have been optimal with regard to the cost landscape, since their creators would obviously not have had access to the full range of cost information, nor to any sophisticated algorithms. An optimal topography-based model may be inappropriate and unsuitable for reconstructing past decision-making processes (see e.g. Whitley 2002). These, on the one hand, involve a certain degree of environmental knowledge (Rockman 2003), and on the other hand concern the dynamics of changing land use, settlement pattern and functional or symbolic landmarks (military and religious sites; the caravanserai system), which influence the structure of a communication system. Depending on the function and aims of the paths and roads, spatial models can provide multiple optimal paths corresponding to the minimization or maximization of specific environmental or cultural criteria, as we did in the case of the visibility criterion (see also Howey 20II). However, the choice of which costs to use in the model, their values and their respective weights are all subjective, and so results will vary depending on these decisions. Furthermore, least cost path modelling will not easily allow us to analyse alternative options. The least cost path routines in GIS will give a single optimal solution, not the second best or nth-best. Even though k-shortest path algorithms, designed to find less optimal solutions, are described in various computer science publications (e.g. Yen I971; Eppstein I998; Hershberger et al. 2007), they are very difficult to achieve with computational efficiency, and have not been implemented in GIS.

The genetic algorithm described by Frommer and Golden (2007a, 2007b) is in fact well suited to address these issues. First of all, the algorithm generates an entire population of solutions, not just one. Furthermore, because it has an element of randomness, it may not return the same "best" solution each time. Uncertainty in costs and their weightings can be reflected in multiple runs of the algorithm. One potentially useful approach would be to run the genetic algorithm numerous times with different cost settings and count how often a given location is found in the least cost solution (or within a set of the top solutions). The results of this simulation across various cost value settings would be to assign a probability that a path passed through a particular location for each location on the map.

The study of the development of settlement distribution, density and hierarchy has recently been carried out using GIS-based techniques that support the interpretation or reinterpretation of the dynamic relationship between supra-regional roads, regional pathways, sites and off-site land use over time (cf. Bell et al. 2002; Fairén Jiménez 2004; Zakšek

I4 For churches as proxies for settlements in the area around Caesarea see Decker (2007, 24I). 
et al. 2008). Other (landscape) theoretical questions still need to be explored, like the influence of different environmental costs and sociocultural factors, and landmarks that attract movement over the long term (Murrieta Flores 20I0), especially where they concern the coherence of road networks, their function and the articulation and use by the local population of primary (i.e., viae publicae) and secondary networks (regional paths) in the Roman period.

Did the local population of the Cappadocian upland, a territory at the eastern frontier of the Roman and then Byzantine Empire, use the structured Roman and Byzantine road system? To what extent is the strategic network connecting central places and stations a product of the previous regional pattern of sites and infrastructures, and/or related to land use and resource exploitation, like mixed farming, agropastoralism and a mining economy? ${ }^{15}$ In this respect we also consider it a relevant issue to examine the location and function of junctions unifying and subdividing the movement (Gibson 2007) along a diachronic network.

The feasibility of exploring these issues is for this case study restricted by the availability of archaeological survey data and fine-grained chronology. However, even for relatively well-known regions it is still very much limited by the availability of software solutions. Even when using off-the-shelf GIS packages, setting up and executing a multitude of different least cost path variants and comparing these is a complex task. The current implementation of the genetic algorithm for the Euclidean Non-Uniform Steiner Tree Problem is suitable for the experimental purpose for which it was applied here, but still needs to be substantially improved in speed, flexibility and accessibility to other users before it can be used to effect in landscape archaeology.

\section{Acknowledgements}

The writing of this paper was made possible partly by a VENI research grant from NWO (the Netherlands Organization for Scientific Research) awarded to Philip Verhagen.

The dataset on Cappadocia was collected by Silvia Polla within the framework of the “Ancient Cartography" Project (2006-2008) at The Karman Center for Advanced Studies in the Humanities (University of Bern).

I5 On agropastoralism see Decker 2007, 256; on the Hittites control of markets and over regional routes for metal exploitation see Yakar (I976); Kaptan I990, 78. 


\section{References}

Bachrach, B.S. (1993)

"Animals and Warfare in Early Medieval Europe", in: B.S. Bachrach (ed.), Armies and Politics in the Early Medieval West, Aldershot, 708-751.

Bellavia, G. (2006)

"Predicting Communication Routes", in: J.E. Haldon (ed.), General Issues in the Study of Medieval Logistics, Leiden, 185-198.

Bell, T. / Wilson, A. / Wickham, A. (2002)

"Tracking the Samnites: Landscape and Communication Routes in the Sangro Valley, Italy", in: American Journal of Archaeology 106, 169-186.

Bell, T. / Lock, G. (2000)

"Topographic and Cultural Influences on Walking the Ridgeway in Later Prehistoric Times", in: G. Lock (ed.), Beyond the Map: Archaeology and Spatial Technologies, Amsterdam, 85-100.

Bevan, A. (20II)

"Computational Models for Understanding Movement and Territory", in: V. Mayoral / S. Celestino (eds.), Sistemas de Información Geográfica y Análisis Arquelógico del Territorio. V Simposio Internacional de Arqueología de Mérida (Anejos de Archivo Español de Arqueología, 383-394.

Chevalier R. (1997)

Les voies romaines, Paris.

Cuntz, O. (ed.) (1990)

Itineraria Romana. Bd. I: Itineraria Antonini Augusti et Burdigalense, Stuttgart.

Decker, M. (2007)

"Frontier Settlement and Economy in the Byzantine East", in: Dumbarton Oaks Papers 6I, $2 \mathrm{I} 7-267$.

De Silva, M. / Pizziolo, G. (200I)

"Setting up a 'Human Calibrated' Anisotropic Cost Surface for Archaeological Landscape Investigation”, in: Z. Stančič / T. Veljanovski (eds.), Computing Archaeology for Understanding the Past. Computer Applications and Quantitative Methods in Archaeology 2000, Oxford, 279-286.

de Soto P. / Carreras, C. (2008)

"Anàlisi de la xarxa de transport a la Catalunya romana: alguns apunts", in: Revista d'Arqueologia de Ponent I6-I7, I77-I9I.

de Soto, P. (2010)

Anàlisi de la xarxa de comunicacions i del transport a la Catalunya romana: estudis de distribució $i$ mobilitat, Barcelona.

Eppstein, D. (1998)

"Finding the k Shortest Paths", in: SIAM Journal on Computing 28(2), 652-673. 
Fairén Jiménez, S. (2004)

“¿Se hace camino al andar? Influencia de las variables medioambientales y culturales en el cálculo de caminos óptimos mediante SIG”, in: Trabajos de Prehistoria 6I(2), 25-40.

Fiz, J. / Orengo, H. (2008)

"Simulating Communication Routes in Mediterranean Alluvial Plains", in: A. Posluschny / K. Lambers / I. Herzog (eds.), Layers of Perception. Proceedings of the 35th International Conference on Computer Applications and Quantitative Methods in Archaeology (CAA), Berlin, Germany, April 2-6 2007. Bonn, 3I6-32I.

Fábrega Álvarez, P. / Parcero Oubiña, C. (2007)

"Proposals for an Archaeological Analysis of Pathways and Movement", in: Archeologia e Calcolatori I8, I2I-I40.

French, D. H. (1974)

"A Study of Roman Roads in Anatolia: Principles and Methods", in: Anatolian Studies 24, I43-I49.

French, D. H. (1988)

Roman Roads and Milestones of Asia Minor, Oxford.

French, D. H. (1998)

"Pre- and Early-Roman Roads of Asia Minor. The Persian Royal Road", in: Iran 36, I5-43.

French, D. H. (2012)

Roman Roads and Milestones of Asia Minor, Vol 3. Milestones, Fasc. 3.3 Cappadocia, British Institute at Ankara, Electronic Monograph 3.

Frommer, I. / Golden, B. (2007a)

"A Genetic Algorithm for Solving the Euclidean Non-Uniform Steiner Tree Problem", in: E.K. Baker / A. Joseph / A. Mehrotra / M.A. Trick (eds.), Extending the Horizons: Advances in Computing, Optimization, and Decision Technologies, New York, 3I-48.

Frommer, I. / Golden, B. (2007b)

"Solving the Euclidean Non-Uniform Steiner Tree Problem Using a Genetic Algorithm", paper presented at INFORMS ICS 2007, College Park (MD), 3 January. http://www.rhsmith. umd.edu/faculty/bgolden/recent_presentation_pdfs_links/2007_jan_ics_frommer.pdf.

Gaffney, H. (2006)

"Superiority of Numbers: Methodologies for Modelling the Behaviour of Armies", in: Haldon J.E. (ed.), General Issues in the Study of Medieval Logistics, Leiden, 25I-272.

Gibson, E. (2007)

"The Archaeology of Movement in a Mediterranean Landscape", in: Journal of Mediterranean Archaeology 20(I), 6I-87.

Golledge R. (2003)

"Human Wayfinding and Cognitive Maps", in M. Rockman / J. Steele (eds.), Colonization of Unfamiliar Landscapes: The Archaeology of Adaptation, London, 25-43. 
Graßhoff, G. / Mittenhuber, F. (2009)

Untersuchungen zum Stadiasmos von Patara: Modellierung und Analyse eines antiken geographischen Streckennetzes, Bern.

Hershberger, J. / Maxel, M. / Suri, S. (2007)

"Finding the k Shortest Simple Paths: A New Algorithm and its Implementation", in: ACM Transactions on Algorithms 3(4), 45:I-I9.

Herzog, I. (2013)

"Theory and Practice of Cost Functions", in: F. Contreras / M. Farjas / F.J. Melero (eds.), Fusion of Cultures. Proceedings of the 38th Annual Conference on Computer Applications and Quantitative Methods in Archaeology, Granada, Spain, April 2010. Oxford, 375-382.

Hild, F. (1977)

Das Byzantinische Strassensystem in Kappadokien, Vienna.

Hild, F. / Restle, M. (198I)

Tabula Imperii Byzantini 2, Kappadokien (Kappadokia, Charsianon, Sebasteia und Lykandos), Vienna.

Hogarth, D.G. (1893)

"Modern and Ancient Roads in Eastern Asia Minor. Part 2: The Military Road from Caesarea to Melitene on the Euphrates", in: Royal Geographical Society (RGS) Supplementary Papers 3, $678-718$.

Howey, M.C.L. (20II)

"Multiple Pathways across Past Landscapes: Circuit Theory as a Complementary Geospatial Method to Least Cost Path for Modeling Past Movement", in: Journal of Archaeological Science 38.Io, October 20II, 2523-2535, Accepted Manuscript, Available online 26 March 20II.

Hucker, R.A. (2009)

"How Did the Romans Achieve Straight Roads?", Paper Presented at International Federation of Surveyors (FIG) Working Week 2009: Surveyors' Key Role in Accelerated Development, Eilat 3-8 May.

Kaptan, E. (1990)

"Findings Related to the History of Mining in Turkey", in: Mineral Resource Exploration Bulletin III, 75-84.

Kolb, A. (2000)

Transport und Nachrichtentransfer im Römischen Reich, Berlin.

Laurence, R. (1999)

The Roads of Roman Italy: Mobility and Cultural Change, New York.

Llobera, M. (2000)

"Understanding Movement: A Pilot Model towards the Sociology of Movement", in: Lock, G. (ed.), Beyond the Map: Archaeology and Spatial Technologies, Amsterdam, 65-84.

Llobera, M. (200I)

"Building Past Perceptions with GIS: Understanding Topographic Prominence", in: Journal of Archaeological Science 28, 1005-IOI4. 
Llobera, M. (2003)

"Extending GIS-based Visual Analysis: The Concept of Visualscapes", in: International Journal of Geographical Information Science I7(I), 25-48.

Llobera, M. / Fábrega-Álvarez, P. / Parcero-Oubiña, C. (20II)

"Order in Movement: A GIS Approach to Accessibility", in: Journal of Archaeological Science $38(4), 843-85$ I.

Meijer F. / van Nijf O. (1992)

Trade, Transport and Society in the Ancient World. A Sourcebook, London.

Miller, K. (1988)

Itineraria Romana. Römische Reisewege an der Hand der Tabula Peutingeriana, Bregenz.

Minetti, A.E. / Moia, C. / Roi, G.S. / Susta, D. / Ferretti, G. (2002)

"Energy Cost of Walking and Running at Extreme Uphill and Downhill Slopes", in: Journal of Applied Physiology 93, I039-I046.

Mitford, T.B. (2000)

"Map 64 Caesarea-Melitene" in: R.J.A. Talbert (ed.), Barrington Atlas of the Greek and Roman World, Princeton.

Mueller, J. (1968)

"An Introduction to the Hydraulic and Topographic Sinuosity Indexes", in: Annals of the Association of American Geographers 58(2), 37I-385.

Murrieta-Flores, P. (2010)

"Travelling in a Prehistoric Landscape: Exploring the Influences that Shaped Human Movement", in: B. Frischer / J. Webb Crawford / D. Koller (eds.), Making History Interactive. Computer Applications and Quantitative Methods in Archaeology (CAA). Proceedings of the 37th International Conference, Williamsburg, Virginia, United States of America, March 22-26, 2009. Oxford, 258-276.

Quilici, L. (1995)

"La Via Salaria da Roma all'alto Velino: la tecnica costruttiva dei manufatti stradali", in: L. Quilici / S. Quilici Gigli (eds.), Strade romane: percorsi e infrastrutture, Atlante tematico di topografia antica 2, Rome, 85-154.

Raepsaet, G. (2002)

Attelages et techniques de transport dans le monde gréco-romain, Brussels.

Ramsay, W.M. (2010)

The Historical Geography of Asia Minor, Cambridge. First published I89o.

Rockman, M. / Steele, J. (eds.) (2003)

Colonization of Unfamiliar Landscapes: The Archaeology of Adaptation, London.

Rockman, M. (2003)

"Knowledge and Learning in the Archaeology of Colonization", in: M. Rockman / J. Steele (eds.), Colonization of Unfamiliar Landscapes: The Archaeology of Adaptation, London, 3-24. 
Roth, J.P. (1998)

The Logistics of the Roman Army at War (264 B.C. - A.D. 235), Leiden.

Snead, J.E. / Erickson, C.L. / Darling, J.A. (2009)

"Making Human Space: The Archaeology of Trails, Paths, and Roads", in: J.E. Snead / C.L. Erickson / J.A. Darling (eds.), Landscape of Movement. Trails, Paths and Roads in Anthropological Perspective, Philadelphia, I-I9.

Tobler, W. (1993)

Three Presentations on Geographical Analysis and Modelling, Santa Barbara, CA.

Tuba Ökse, A. (2007)

"Ancient Mountain Routes Connecting Central Anatolia to the Upper Euphrates Region", Anatolian Studies 57, 35-45.

van Leusen, M. (2002)

Pattern to Process: Methodological Investigations into Deformation and Interpretation of Spatial Patterns in Archaeological Landscapes, Groningen, http://dissertations.ub.rug.nl/faculties/ arts/2002/p.m.van.leusen/ (seen on I2/03/2013)

Verhagen, P. / Jeneson, K. (2012)

"A Roman Puzzle. Trying to Find the Via Belgica with GIS", in: K. Papadopoulos / P. Murrieta Flores / A. Chrysanthi (eds.), Thinking beyond the Tool: Archaeological Computing and the Interpretive process, Oxford, I23-130.

Whitley, T.G. (2002)

"Modeling Archaeological and Historical Cognitive Landscapes in the Greater Yellowstone Region (Wyoming, Montana and Idaho, USA) Using Geographic Information Systems", in: G. Burenhult / J. Arvidsson (eds.), Archaeological Informatics: Pushing the Envelope. CAA 200I. Computer Applications and Quantitative Methods in Archaeology. Proceedings of the 29th Conference, Gotland, April 200I. Oxford, I39-I48.

Witcher, R.E. (1998)

"Roman Roads: Phenomenological Perspectives on Roads in the Landscape", in: C. Forcey / J. Hawthorne / R.E. Witcher (eds.), TRAC 97. Proceedings of the Seventh Annual Theoretical Roman Archaeology Conference, University of Nottingham, April I997. Oxford, 60-70.

Yakar, J. (1976)

"Hittite Involvement in Western Anatolia", in: Anatolian Studies 26, II7-I28.

Yen, J.Y (I97I)

"Finding the k Shortest Loopless Paths in a Network", in: Management Science I7, 7I2-716.

Zakšek, K. / Fovet, E. / Nuninger, L. / Podobnikar, T. (2008)

"Path Modelling and Settlement Pattern", in: A. Posluschny / K. Lambers / I. Herzog (eds.), Layers of Perception. Proceedings of the 35th International Conference on Computer Applications and Quantitative Methods in Archaeology (CAA), Berlin, Germany, April 2-6 2007. Bonn, 309-315. 



\section{Developing computational approaches for the study of movement: assessing the role of visibility and landscape markers in terrestrial navigation during Iberian Late Prehistory}

\section{Introduction}

The topic of movement in archaeology has been extensively studied. Research on human movement during prehistory has become in archaeology and anthropology one of the bases for understanding the dynamics of social and economic relationships, technology, social identity and territoriality, among many other important themes. Although archaeological investigations related to movement have increased in the last decade, the majority have usually relied on "static" evidence, that is, on the analysis of the materials or objects that are found in specific sites, establishing the relationship between them and their points of origin or destination (Branting 2004). In recent years, using spatial technologies, more research has aimed to investigate movement from a landscape perspective, in which more attention has been paid to the processes that may have happened on journeys. Some of these studies have directly or indirectly analysed the possible factors influencing the decisions about which paths to take, the mechanics of movement and the archaeological evidence related to it (Llobera 2000; Fairén Jiménez 2004; Cruz Berrocal 2004; Fábrega Alvarez 2006; Fábrega Alvarez / Parcero Oubiña 2007; Llobera / Slukin 2007; Fiz / Orengo 2008; Murrieta-Flores 20Iо, 20I2a; Mlekuž 20I0; in the current volume, Lock et al. and Mlekuž among others). In the specific case of Iberia, megalithic monuments are among the archaeological elements at a landscape scale that have been linked to potential patterns of movement, and it has been argued that, besides their symbolic and funerary meanings, they may also have been utilized as landscape markers.

The idea of prehistoric monuments as markers can be traced in archaeology to the I970 with the adoption of Saxe's (I970) Hypothesis No. 8 by researchers like Fleming (I973), Renfrew (I976) and Chapman (I98I). These authors proposed that megalithic monuments may have been used as markers with territorial connotations. Nonetheless, due to the physical and spatial characteristics of the monuments, other hypotheses have also arisen, especially in Iberian archaeology. These theories have pointed out that megalithic monuments were not only an important element structuring prehistoric landscapes, but also that they tend to sustain spatial relationships with historical pathways. This has

* University of Chester, History and Archaeology Department, UK. 
opened up the question of their possible use as markers, but with a different connotation from that of territorial definition. The idea of an association between historical pastoral routes and megaliths has been sustained not only by the strong transhumant tradition of the Iberian Peninsula, but also by the archaeological record, which points to the practice of mixed economies with an important emphasis on mobile pastoralism during late prehistory (Galán Domingo / Martín Bravo I99I-I992; Ruíz-Gálvez / Galán Domingo I99I; Criado Boado I993; Galán Domingo I993; Galán Domingo / Ruíz-Gálvez 200I; Murrieta Flores et al. 2011a; Murrieta-Flores 2012a; Murrieta-Flores 2013; Wheatley et al. 2010). These ideas have resulted in the hypothesis that megalithic monuments may indeed have acted as landscape markers, but may also have played a visual role as waypoints in terrestrial navigation during the journeys performed by these societies. Although the employment of megaliths as landscape markers during prehistory has been implied in many investigations, there has never been a specific study on Iberia to test the spatial relationships observed in the field. In addition, the concept of landscape markers has been frequently used, but never defined in the context of archaeological studies.

The purpose of this chapter is to investigate the possible role of megalithic monuments in terrestrial navigation through the development of computational methodologies using Geographic Information Systems (GIS). In order to accomplish this, we will test the hypothesis of their potential use as waypoints along pathways, using as a case study the archaeological evidence available of Copper Age (circa 3I00-2Ioo BC) societies of the mountain region of western Sierra Morena in Andalucia, Spain.

\section{Landscape markers}

The first task in testing the hypothesis of the use of monuments as landscape markers by prehistoric societies is to define what is to be understood as landscape markers. For that, it is necessary to take into account that there are many different variables and factors (social, economic and environmental) that can influence how people navigate through the landscape (Fairén Jiménez 2004; Murrieta-Flores 2010). Social relationships between groups, territorial conflicts, ideas regarding certain spaces or regions, geographical knowledge, types of terrain, time expended on travel, velocity of movement, access to basic resources while travelling and loads carried are of the greatest importance in the study of movement, as they define the routes people take. Along with these and other factors, terrestrial navigation, or the ability to orient oneself within the landscape, is essential in order to make a successful journey. That is, to follow a route, in order to get to a desired destination and to return to a point of departure, people have to acquire a series of skills. Research in experimental psychology has established that wayfinding is one of the most important of these abilities, and it consists in the process of defining and following a route from one place to another (Golledge I999). The development of this skill is possible thanks to the creation of 
cognitive maps, which allow the construction of mental representations of the ideas that we hold regarding space and places, the environmental features that can be perceived and the spatial connections and relationships that they sustain (Murrieta-Flores et al. 20Irb). Thus, to carry out a journey, the traveller will have to establish points of origin and destination, know the places where he/she needs to deviate, be able to recognize spatial markers and understand the complete route within a larger frame (Murrieta-Flores 20I0). Therefore, the recognition of outstanding features in the landscape, or waypoints, plays a fundamental role in human movement (for a complete discussion on the theory and definition of landscape markers see Murrieta-Flores 20Iıb; 20I2b).

\section{Megaliths as waypoints in Iberia}

Although it has been generally accepted that the emergence of megalithic tombs seems to be related to the first evidence of a wish by communities to delimit their space, in the case of Iberia they have also been associated with crossing places and markers (Galán Domingo / Martín Bravo I99I-92; Andrés Ruperéz I999; Galán Domingo / Ruíz-Galvez 2001, 264; Gómez Vila 2005, 407). Therefore, mobility has been considered one of the main variables influencing the location of mounds and megaliths, suggesting that they may have been used as waypoints (Criado Boado et al, 1994, 39).

Observations giving support to this theory have been made since the Iوth century, when Silvelo (I887, in Gómez Vila 2005, 406) affirmed that megaliths were found along Roman paths, and that they were normally positioned on both sides of the road. Later, as a consequence of early research tracing the Antoninan route, Diaz Sanrujo (I906, in Gómez Vila 2005, 406) stated that the presence of megalithic monuments was a strong indication of the existence of ancient paths, arguing that the most favourable crossing places in a watershed would be the ones with megalithic monuments nearby. He also declared that this assertion was so accurate that new roads were actually being constructed by identifying these places. Later, during the early 2oth century and after some decades of discussion of these theories, Maciñeira (I943 and I947, in Gómez Vila 2005, 407) documented 87 monuments along $40 \mathrm{~km}$ of both sides of the Camino Real (royal pathway), and found traces of wheel tracks in various sections of the excavation along the road. In his report, the author not only argued that there was a relationship of intervisibility between the monuments and the road, but also concluded that, in a landscape with little vegetation, these monuments were in fact acting as waypoints along the route. More recent spatial analyses have also led to the conclusion that megalithic monuments were associated with pastoral activities due to their spatial linkage with transhumance routes (Criado Boado et al. I990-91; Criado Boado et al. 1994, 39; Galán Domingo / Ruíz-Galvez 200I; Murrieta Flores 2007; Wheatley et al. 2010; Murrieta-Flores 2012a).

This association seems particularly important in terms of terrestrial navigation, as transhumant pastoralism constitutes a strategy that involves the movement of cattle, travel- 
ling long distances between different altitudes to undertake seasonal exploitation of pastures in the mountains during the summer and the pastures of the lowlands during the winter (Ehlers / Kreutzman 2000, I6). This activity is recorded in Iberia in medieval times and, although it has been argued that its practice during prehistory is improbable because it was a specific phenomenon produced by the historical circumstances of the Middle Ages (Chapman I979; Walker I983), it can be suggested that short-distance transhumance (also known as trasterminancia) was possible. At the same time, other studies have emphasized that the monuments seem not to be related exclusively to historical routes, but also to transit zones in general. Research carried out in Aranga, Monfero, La Coruña and Lugo (Galicia) has established a linkage between mounds, paths and privileged communication zones (Criado Boado I99I; Criado Boado et al. I990-I99I, 33-34; Eguileta Franco I994; Villoch Vázquez 200I; Gómez Vila 2005). The region of Cantabria has also been prolific in terms of observed associations between menhirs and passageways in watersheds such as Collado de los Sejós (Santander) (Bueno Ramírez et al. I985). A similar association has been observed for megalithic monuments in the Tajo River Basin (Galán Domingo / Martín Bravo I99I-I992), where their location seem to be related to vados or fords along the river. In this sense, although some of the evidence collected up to now indicates that megalithic monuments were located at the sides of possible transhumance routes, in other cases it seems clear that megaliths were also located at crossing points, perhaps acting as "nodes" or waypoints along routes, marking or commemorating a specific locus of transit or spots where rivers can be crossed.

The location of the monuments is only one of the qualities observed that is deeply related to the theories of why and how megaliths played the role of landscape markers. Monumentality is another of the characteristics that have led archaeologists to conclude that such a use is possible. Prehistoric societies seem to have maximized this effect, constructing the monuments in visible or prominent points of the landscape such as hills or crests. In some examples it seems that they even enhanced their visibility, using white quartz for their construction (Bueno Ramírez I987). However, monumentality as a characteristic of megaliths in their use as landscape markers is difficult to assess, as there is a difference or variability in the investment devoted to the construction of these monuments in different parts of Europe. In terms of movement, differences in monument size probably had repercussions in the way a traveller perceived or understood the landscape and, therefore, the role of the monuments in mobility.

In any case, it is beyond reasonable doubt that megalithic monuments were constructed to be noticed by people and to remain as part of the memory of groups and the landscape for generations. For these societies, megalithic monuments (funerary or ritual) constituted established milestones. As such, not only were they present in the social imagination through their communal and symbolic connotations, but, because of their monumentality, they also formed part of society's physical reality as principal components of their established landscape. In terms of research, although the concept of the use of mega- 


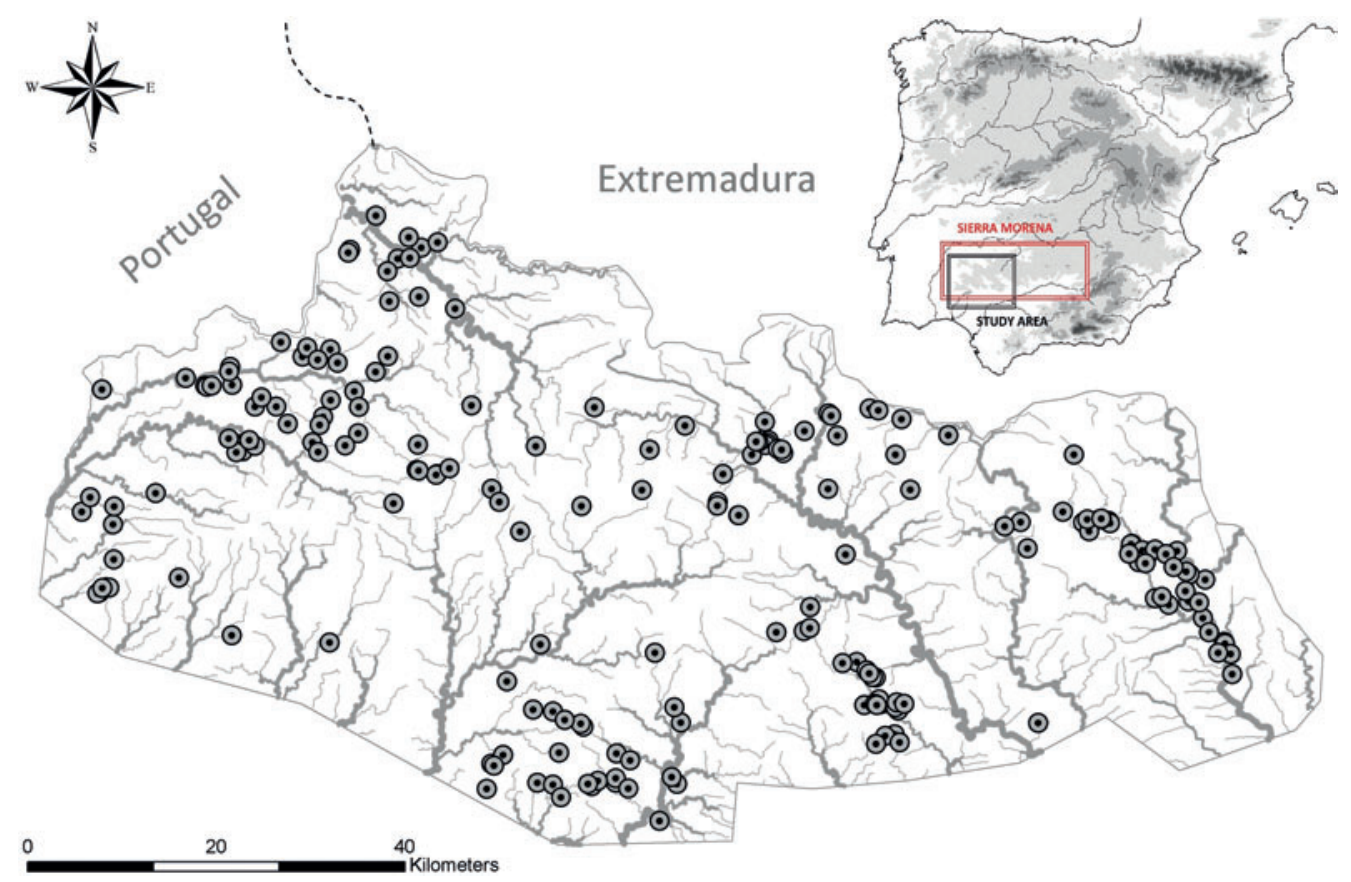

Fig. 1 Situation of Sierra Morena in Iberia; western Sierra Morena and all the Copper Age sites recorded.

liths as landmarks or waypoints has been explored mainly from a theoretical point of view, it remains necessary to implement robust methodologies in order to establish whether different dynamics in their use can actually be observed. As a case study, we selected one of the most important mountain regions in Iberia.

\section{The case of western Sierra Morena}

Sierra Morena is a mountain range which constitutes the zone of contact between the Spanish Central Plateau and the Betic Depression and which crosses the northern extreme of Andalusia, covering $400 \mathrm{~km}$ from east to west (Figure I). It is located between two of the most fertile agricultural river valleys of southern Iberia (Gualdalquivir and Guadiana), and it has been characterized by its richness in terms of mineral resources, but also by its extreme poverty in terms of agricultural potential. In recent years, this region has been the subject of a range of diverse projects aiming to understand the settlement patterns and the megalithic phenomenon (Pellicer Catalán / Hurtado Pérez i980; Piñón Varela I987; I988; Martínez Rodríguez / Lorenzo Gómez i992; Pérez Macías i983; 1986; 1987; 1994; 1996; I996b; I996c; I999; 2010; García Sanjuán et al. 2002; García Sanjuán / Vargas Durán 
2002; García Sanjuán et al. 2004; García Sanjuán et al. 2006; Hurtado Pérez et al. 201I). Thanks to these studies, a more complete picture of the societies that inhabited this mountain range has been acquired.

The region of western Sierra Morena (comprising Sierra de Huelva and Sierra Norte de Sevilla), has come to be of particular interest due to the fact that societies during Late Prehistory, and especially during the Copper Age (3100-2100 BC), seem to have had not only a different kind of access to resources compared with those in the valleys, but also an alternative social organization. According to the studies of settlement pattern, during this period there was a general growth of population, and new settlements were also established in places where there were none before and different kinds of habitats were apparently used, ranging from larger settlements to apparent seasonal camps. On a regional scale, western Sierra Morena acts in many ways as a kind of border area with respect to its surroundings. In terms of its material culture, and mainly in its pottery, the Chalcolithic sites of western Sierra Morena seem to share many characteristics with those in the Guadalquivir Valley, eastern Andalusia and the southwest in general (Pérez Macías i994, 4). However, its difference from the neighbouring regions seems to be more related to the particular environment of the sierra; this is reflected in the subsistence activities, which are closely tied to mobile herding, due to the almost non-existent potential for agricultural activities, in contrast to the mainly agricultural character of the adjacent valleys.

From the 388 sites recorded by various projects in the area of the western Sierra Morena, II3 megaliths and megalithic cists have been included in the study. Only a few menhirs (4) and sites with rock art (2) have been recorded; although it is known that they are not the only ones in existence, they are the ones with exact co-ordinates available.

\section{Assessing the use of megalithic monuments as markers through visibility analyses}

As explained before, several theories to explain the observed empirical association between megalithic monuments and pathways have been discussed in recent years. In the specific case of western Sierra Morena, pastoralism probably started in the Neolithic, and the need for pasturage may have been one of the main motors for movement. Recent research has concluded that late prehistoric societies of this region probably practised short-distance transhumance and that their symbolic sites were deeply related to their dynamics of movement (Murrieta-Flores 2007; 20I2a). These studies have also recorded a strong spatial relationship between monuments and herding pathways, pointing to the possible role of these sites as stations in pastoral orbits. As important spatial markers, one possible explanation for this observed relationship is that monuments could have served as waypoints for terrestrial navigation during the transhumant cycles. As explained before, megalithic monuments offer all the characteristics desired in a landscape marker, not only through their distinctive shape and size, but also because of their deep symbolic and social importance. 
To test if they could have been used as waypoints we can make use of GIS visibility analysis. As observed above, there are many factors that may influence how humans move. However, one of the main and most important prerequisites for navigating while travelling is the use of vision. Visibility becomes a critical factor in terrestrial navigation because it is through vision that we can identify the markers or waypoints (including celestial bodies) that will allow us to take decisions regarding the next direction to take while travelling. In this sense, in order to investigate if the megalithic monuments could have acted as waypoints, we need to establish if they were actually visible along possible travelling routes rather than merely close to them. The visibility of the monuments becomes essential as, in this case, the possible spatial relationships between waypoints and travellers (and therefore the cognitive maps that are constructed) are generated in a dynamic way as the observer moves along a route. The specific aim of the experiment presented in this chapter is thus to investigate a possible visual structuring of the landscape in relation to the monuments, by means of a visibility study that analyses the relationships between natural corridors and the monuments as the traveller moves along the paths.

Although this seems straightforward in a sense, it is necessary to take into account two specific considerations in our case study. Firstly, due to the observed close spatial relation that the monuments sustain with natural corridors (Murrieta-Flores 20I2a), the visibility patterns that we may detect could be product of a cross-correlation. That is to say, they might be visible from the corridors because they are close to them, or, on the other hand, they might be close because from those positions they are visible. Both connotations have important implications for the interpretation of the patterns left by these societies. In the first case, it could imply that the monuments were built along the paths for practical reasons, like easy transport of building materials, for instance; in the second case, it could imply that the monuments were located near to the pathways with the purpose of being visible, due to symbolic or traditional activities like ceremonial processions or marking stations within herding orbits. Although this is a complex question that will not be solved in this study, the following analyses provide some pointers towards fresh ideas. The second consideration that needs to be taken into account is that many aspects of terrestrial navigation are deeply related to movement. While it is possible to confirm through a GIS-based visibility analysis whether the monuments are visible from the routes or not, mapping the visual changes that occur within the landscape in those terms will not necessarily reveal specific perceptions of the landscape while travelling. ${ }^{\mathrm{I}}$ Nevertheless, features created purposefully for terrestrial navigation usually tend to be strategically located to be as visible as possible. In this sense, we can not only explore how constant the view of a monument is within the rate of visual change along a route, but we can also identify those locations on which one or more features have a visual impact. This can help us to understand the visual

I For an extended discussion of this and other difficulties such as the role of vegetation, etc., see MurrietaFlores, 20I2b. 


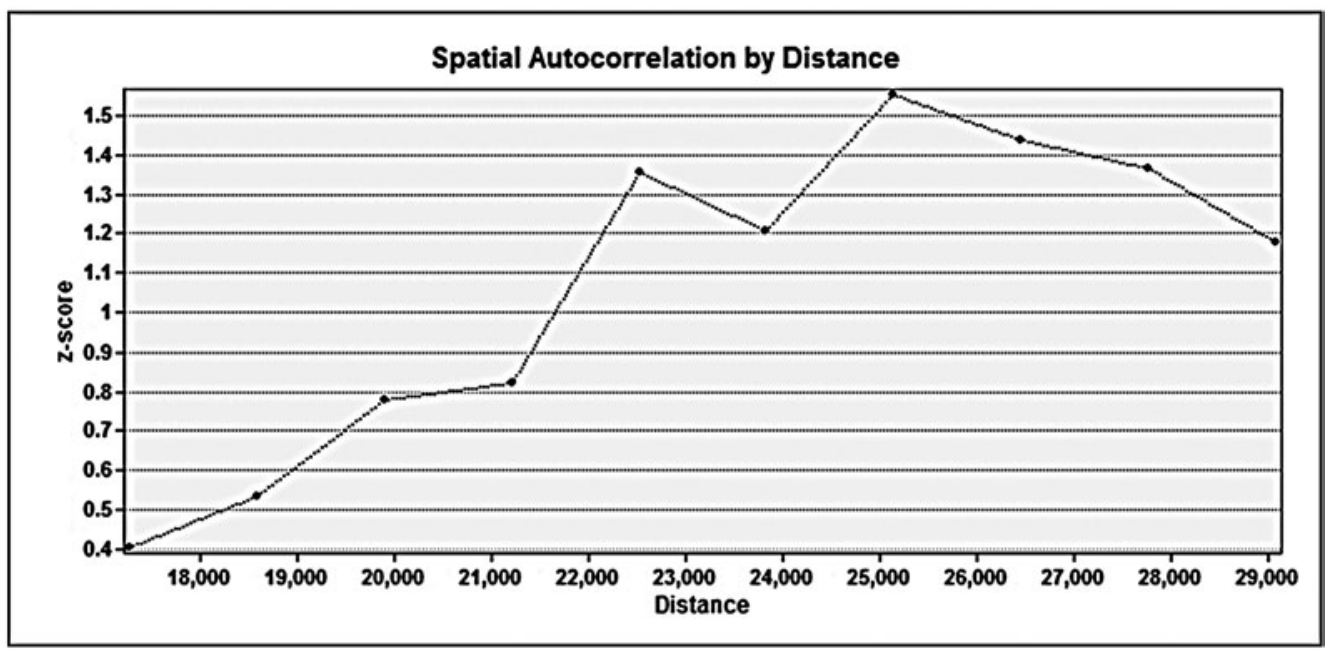

Fig. 2 | Moran's I-Z Score of the megalithic monuments.

structure of the megaliths from corridors, allowing us to detect whether there was an intentionality behind the location of these monuments that could be related to both visibility and movement.

\section{Constructing visibility methodologies: \\ Parameters and technical development of the analyses}

As said above, visibility is subject to important factors related to scale, such as distance. Because visibility decays with it and due to the fact that to navigate people have to be within a "close" range of a waypoint in order to see it, a sub-regional scale was chosen to carry out this experiment. Following the recommendations made by Wheatley and Gillings (2002, 209) regarding the selection of study areas, it was decided to perform spatial statistics to divide the entire region into groups of monuments.

In order to select the study sub-regions, a Kernel Density Analysis was carried out. This method is used to calculate the magnitude per unit area of points, identifying possible clusters. In this analysis it was considered of importance to establish an appropriated neighbouring search radius, because it influences how the kernel density is performed. In order to do that a spatial autocorrelation test (Moran's I) was carried out, establishing a statistically significant radius to carry out the kernel density. From the results obtained in the Moran's I test, the peak of the Z score (which measures how intense the cluster is) was chosen and used as search radius for the Kernel Density analysis (Figure 2). The output indicated five major clusters. In reality the Aroche area (western cluster) shows a more con- 


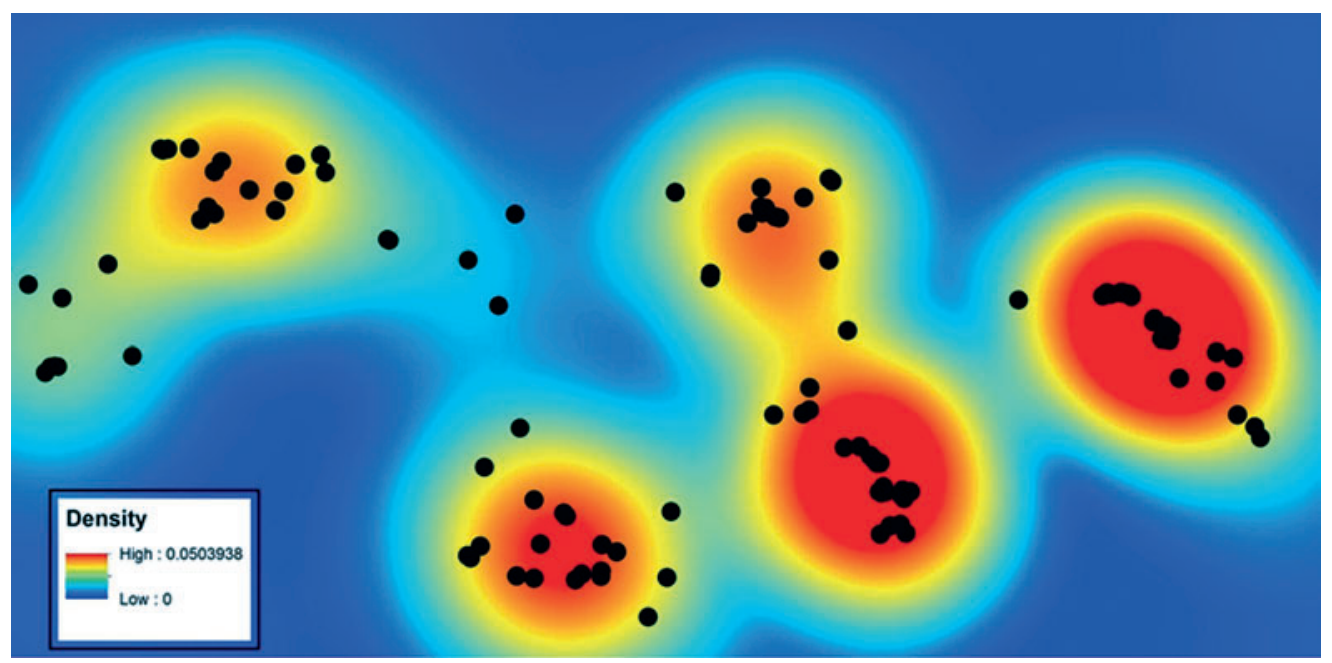

Fig. 3 | Result of the Kernel Density for the definition of clusters.

sistent concentration in its northern part, and for this reason, as well as for analytical purposes, it was decided to derive a sixth group (Figure 3).

In this manner, the sub-regions established are: Almadén de la Plata (Group I), Castillo de las Guardas (Group 2), Aracena (Group 3), Zalamea la Real (Group 4), Aroche (Group 5) and Santa Bárbara de Casa (Group 6). It also has to be noted that the region of the Murtigas River could not be considered within this analysis due to the fact that there is only one monument recorded in that area (Figure 4).

For the visibility analyses and in order to approximate more accurately human vision, the vertical angle range considered was between +IO and -I5 degrees, as suggested by the results of some physiological studies consulted (Ogburn 2006). In terms of the visibility range, while in optimal conditions it has been established that a range between $23-39 \mathrm{~km}$ is acceptable (Ogburn 2006), in management and archaeological studies the visual ranges used have been more conservative (I5-18 km and 3-6 km respectively) (Wheatley I995; García Sanjuán et al. 2006). We decided to use a threshold of $3 \mathrm{~km}$, assuming a theoretical maximum viewshed of $28.2 \mathrm{~km}^{2}$.

As said above, the idea behind this experiment was to test if the megalithic monuments could act as waypoints for terrestrial navigation. According to the theory developed on landscape markers (Murrieta-Flores et al. 20IIb; Murrieta-Flores 20I2b), to fulfil this condition, monuments are expected to present one or more of the following characteristics:

(I) they should tend to be considerably visible from the natural corridors or passageways,

(2) the dominant direction of their fields of view should be those orientated towards the natural corridors, and 


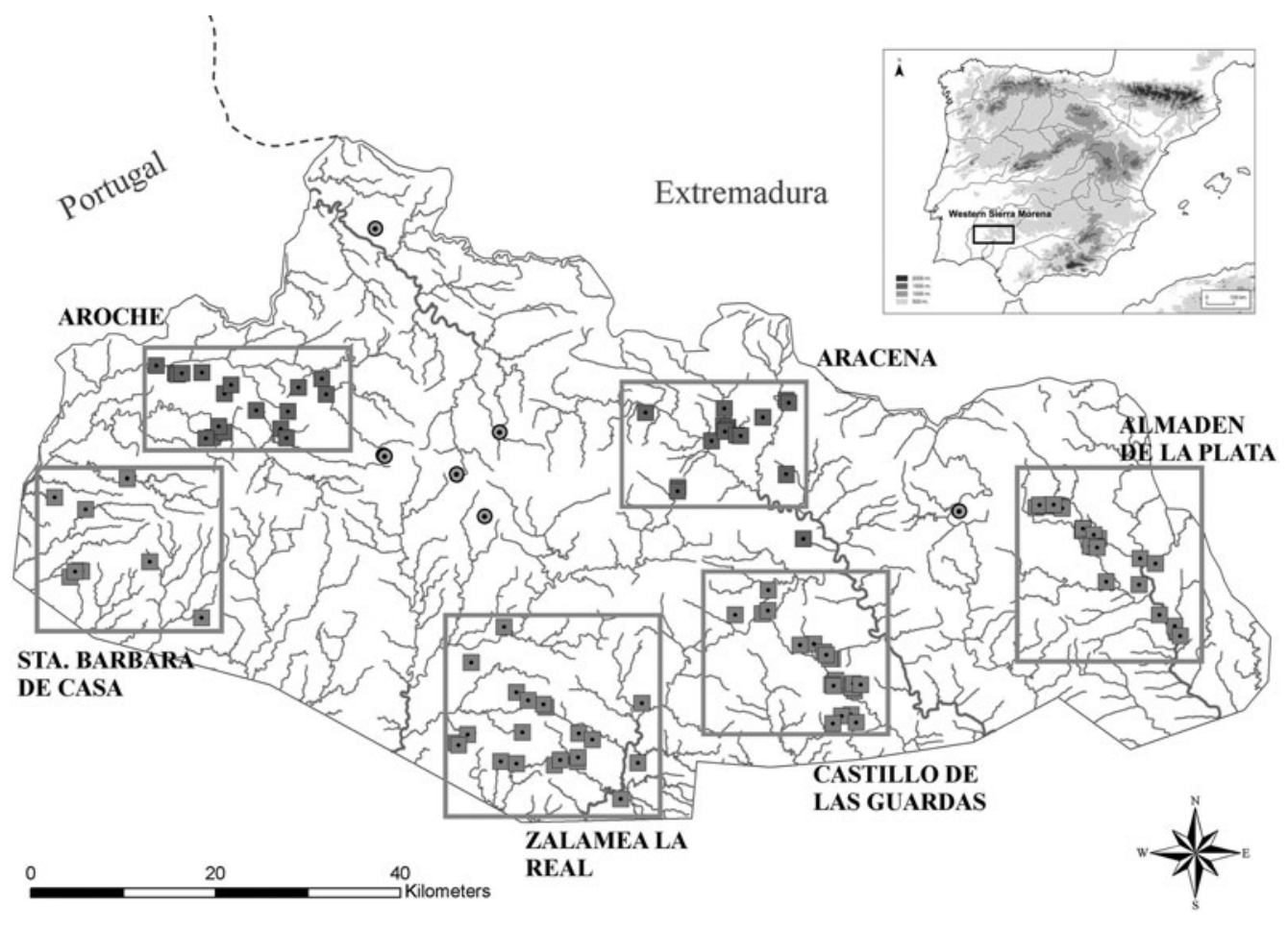

Fig. 4 | The 6 groups defined for the visibility analyses.

(3) they should be located in a distance range from the corridors that makes them more likely to be visible and therefore used as waypoints.

In order to test these ideas, three different spatial analyses were developed.

In the case of the first characteristic - that the monuments should tend to be highly visible from the natural corridors or passageways - a binary viewshed analysis could be used to simply test whether monuments are visible or not from natural corridors. ${ }^{2}$ However, if they are also visible from many other locations within the landscape, their visibility may not be regarded as a determinant attribute in their role as waypoints for terrestrial navigation. This is not to say that in order to function as landscape markers, the monuments should only have to be visible from the routes. However, if they acted as waypoints, a closer visual relationship between monuments and routes could be expected than between any random point in the landscape and routes. In order to test this, we conducted viewshed analyses and documented the parts of the natural corridors from which the monuments are visible

2 These corridors were established in a previous study that also used GIS methods; the full documentation of their calculation can be consulted in Murrieta-Flores $20 \mathrm{I2}$. 


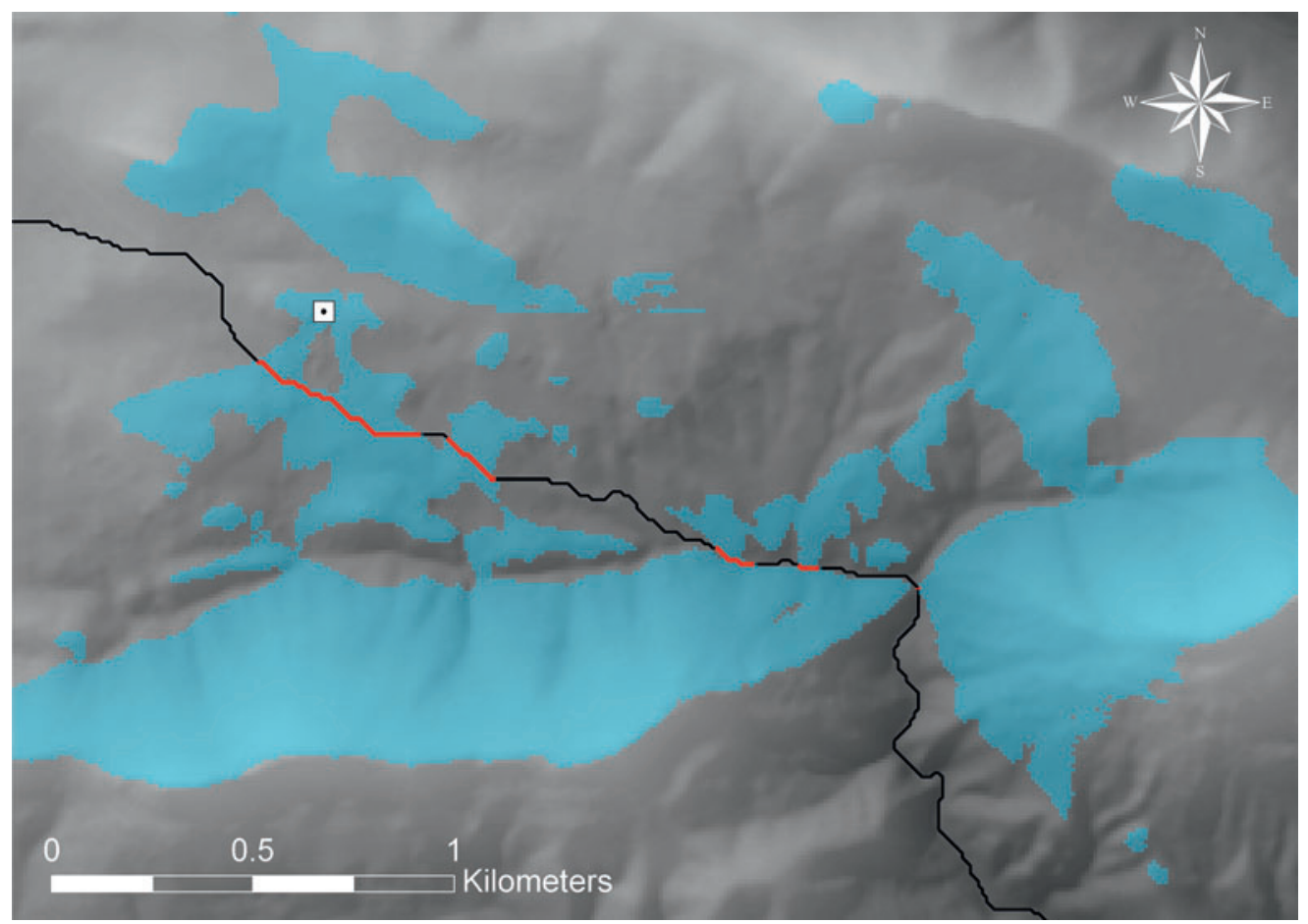

Fig. 5 | Segments of the natural corridors from which a particular monument is visible (in red). Dolmen de Gabino in Almadén de la Plata.

(Figure 5). The same was done with a sample of random points, and later both cases were compared through a statistical test of significance. The purpose of this was to establish if there is a difference between the two samples. The idea behind this is to investigate whether the monuments occur in locations that are more visible from the natural corridors than would be expected by chance alone.

The test chosen was the Kolmogorov-Smirnov test and it involves the comparison of the cumulative frequency distributions of the two independent samples. In this case the null hypothesis set for all groups was: $\mathrm{Ho}=$ The megalithic monuments are randomly distributed with respect to their visibility from natural corridors. Following the method described, a total of six tests were conducted at a significance level of 0.05 , assessing each of the sub-regions established.

These procedures were set as the base analysis in order to explore whether we can observe significant relationships between the visibility of the monuments and the corridors. In addition to this, with the record of the segments of corridors from which the megaliths are visible, it was possible to explore certain characteristics between these parts of the landscape and the monuments. In this manner, profiles of the visual exposure to monuments 
from corridors were also produced from the visibility analysis. This was aimed at graphically visualizing the continuity in the visibility of monuments along the corridors, and to quantify in each of the sections how many megaliths might have been visible at the same time (Figure 6).

In the case of the second characteristic to be explored - that the dominant direction of the monuments' fields of view should be those orientated towards the natural corridors an analysis investigating the possible dominant directionality in the fields of view of the monuments was carried out to assess whether these are in places that favour or promote their visibility from the routes or, in other words, whether there is a pronounced directionality in their fields of vision that promotes a visual relationship with natural corridors. The method followed here is the one proposed by Wheatley and Gillings (2000). The analysis consists in the calculation of a simple binary viewshed of the viewpoint (the monuments in this case), the calculation of its Euclidean Direction, then the reclassification of this raster into directional zones (N, NE, E, SE, S, SW, W and NW). Finally, the binary viewshed is overlaid with the reclassified Euclidean direction in order to quantify the dominant directionality in the viewshed (Figure 7).

A table with the results of this analysis was created for each group in order to quantify the predominant directions of view of all monuments. Once the dominant directions for each megalith were identified, it was examined whether a natural corridor passed through it or not. This was used to calculate the percentage of monuments whose main direction of view is oriented towards a natural corridor. In order to investigate if the coincidence observed between them could be a matter of chance, a I-sample Chi-square statistical test was also conducted. The purpose of this was to identify in a robust way any possible pattern of visual structuring that might indicate a preference for locating the monuments in places that favoured visibility towards and/or from corridors. In this case, a null hypothesis was formulated as: $H o=$ The natural corridors are equally distributed across dominant and nondominant fields of view of the monuments. The test was carried out at a significance level of 0.05 .

To test the third characteristic mentioned - that the monuments be located in a distance range from the corridors that makes them more likely to be visible and therefore used as waypoints - a Higuchi viewshed analysis was conducted. However in this case, instead of using the distance index proposed by Higuchi (1988), we created particular ranges for our study areas that take into account field observations and the experience of Llobera's study (2007b). Higuchi's example was adopted for this experiment in terms of the methodology followed to establish distance ranges (measuring the angles that a particular object occupies in a field of view, and deriving the distances from this). However, instead of using as reference a natural element such as trees, we decided to take an archaeological element, in this case the megalithic monuments. This was thought to be more appropriate, because we are interested particularly in the effect of distance on the visibility of monuments and not on the general landscape. 

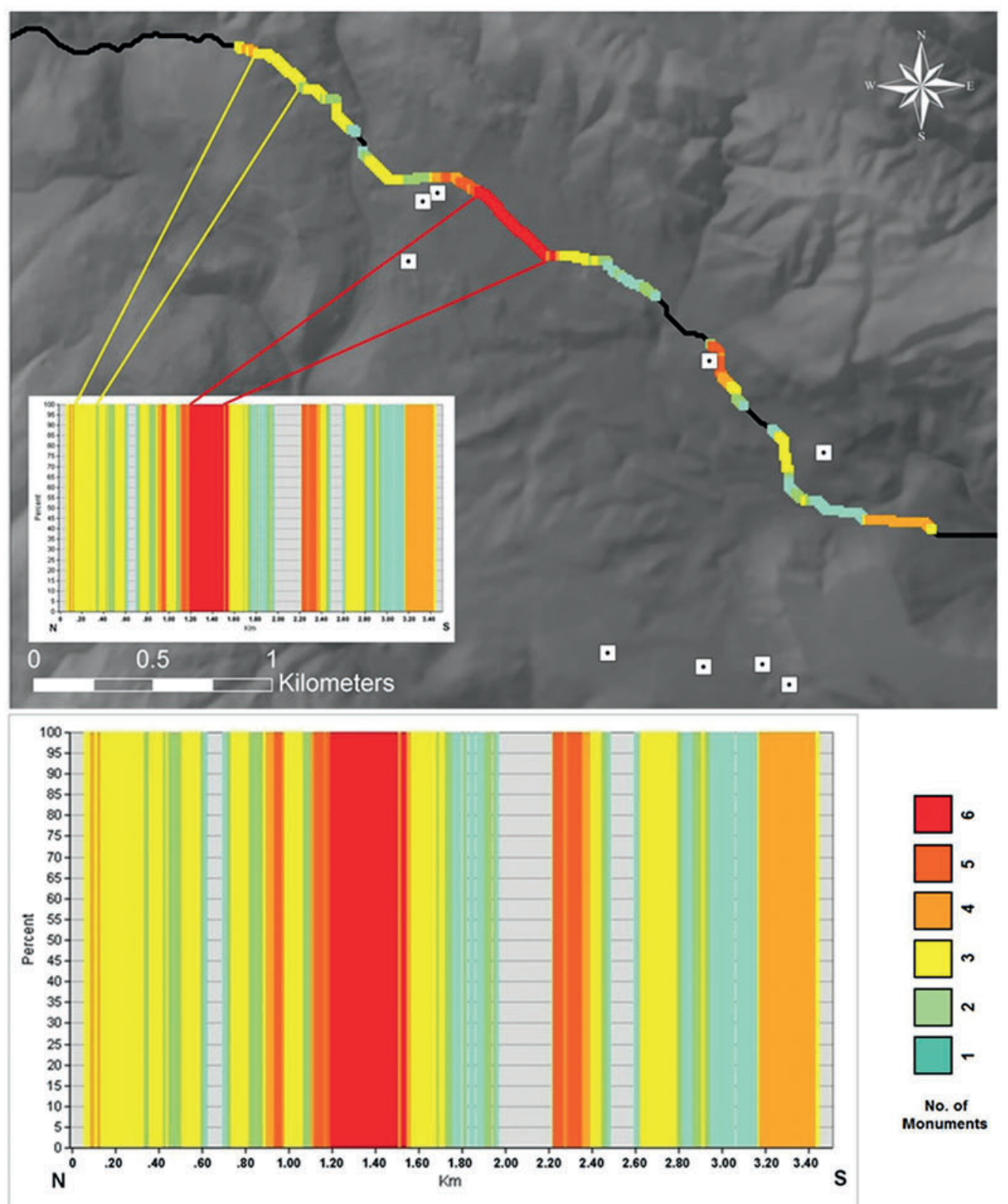

No. of Monuments

Fig.6 | Example of the profile of visual exposure to monuments from a route in Almadén de la Plata. 

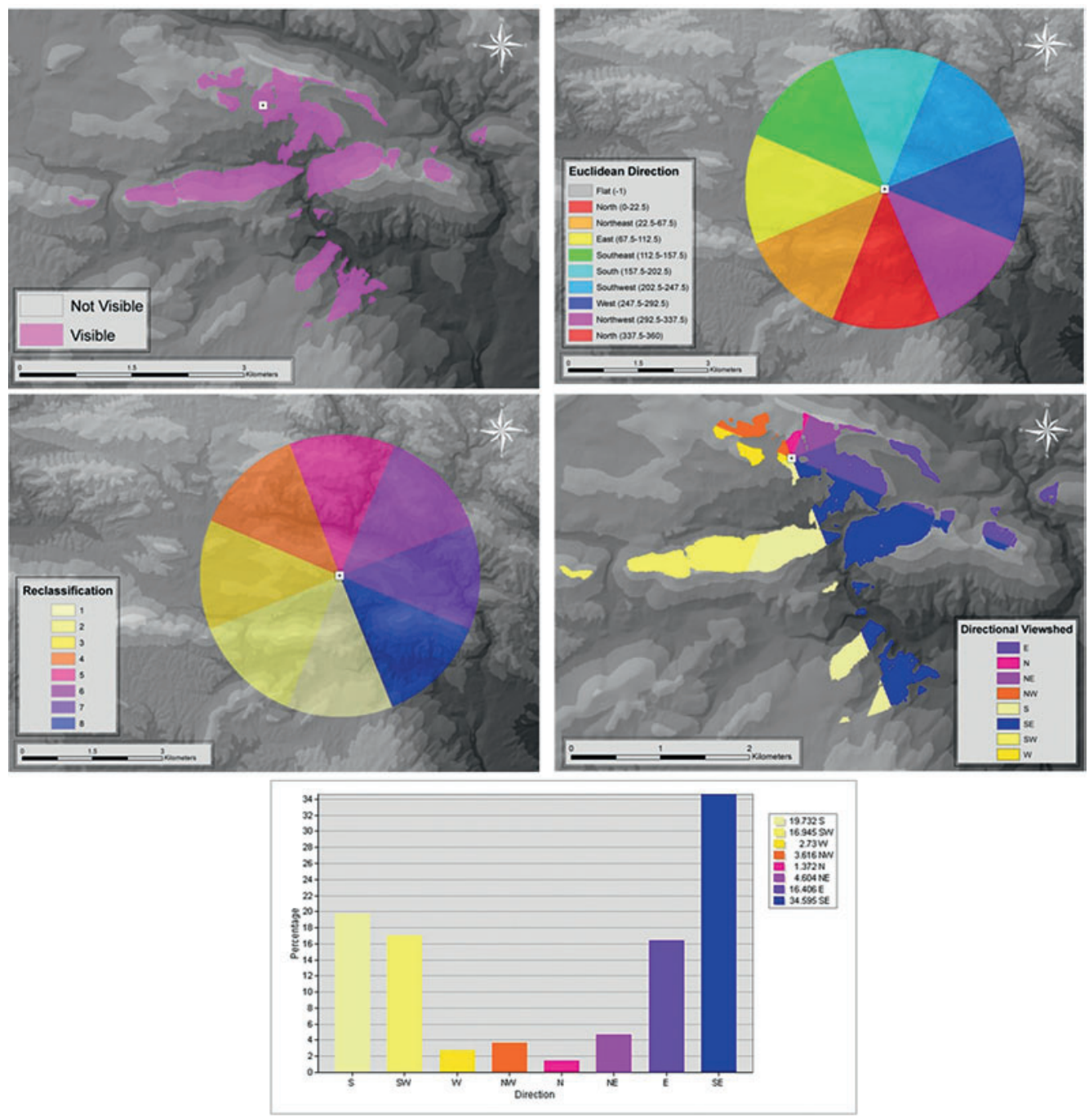

Fig. $7 \mid$ a) Simple binary viewshed; b) Calculation of Euclidean Direction; c) Reclassification of Euclidean Direction; d) Overlap of viewshed and direction; e) Graphic showing the predominant direction of the viewshed. 

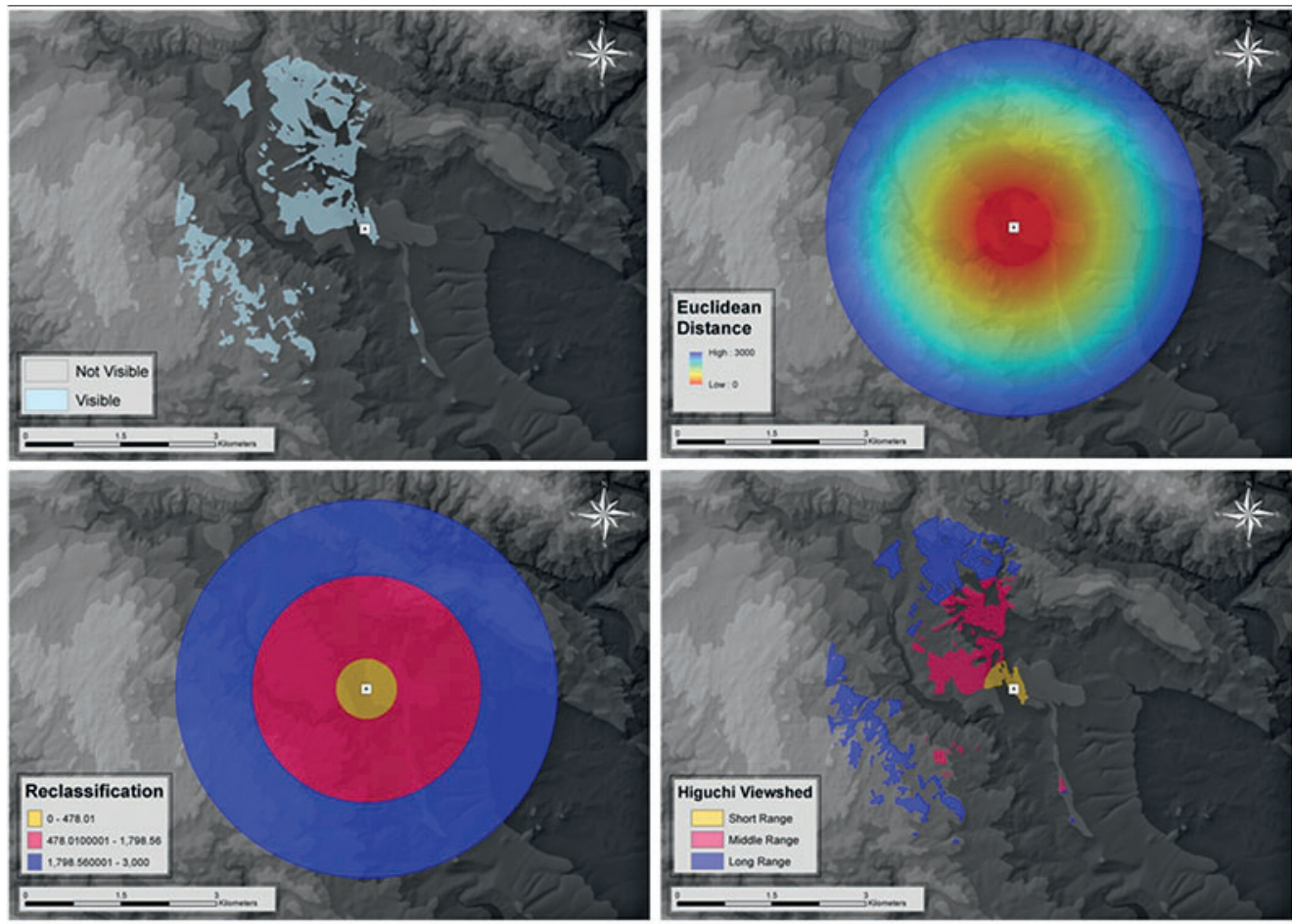

Fig. 8 | Procedure to generate a Higuchi viewshed: a) Binary viewshed; b) Calculation of Euclidean Distance; c) Reclassification to the index established; d) Combination of both.

The method proposed by Wheatley and Gillings (2000) was followed, but particular distance ranges were adopted in this case. The analysis consisted in the calculation of the viewshed from the point of interest and its classification into meaningful distance ranges. The classification used in this case is based on a field experiment conducted by looking at a particular monument and its integration into the general landscape. This was done in a similar way as Higuchi did in the case of trees, and Llobera (2007b) in the case of monuments. Taking a monument with a height of $2.5 \mathrm{~m}$, the visual angle that occupies the monument in the field of view of an observer was measured, establishing alpha $(\alpha)$. The distance ranges were calculated according to the field observations, taking into account that the closer the observer, the wider the angle (Figure 8). The method followed has been described elsewhere (Murrieta-Flores 20I2b) and it is sufficient to say that the angles were measured with an inclinometer. In this manner, the ranges were defined as follows:

Short Range: $\alpha$ larger than $0.3^{\circ}$. Activities closely related to the monument probably happened at this range. At a larger scale the monuments act as reference points in the landscape, they are very well defined and their shape can be easily identified. A person can be recognized effortlessly in their surroundings. 


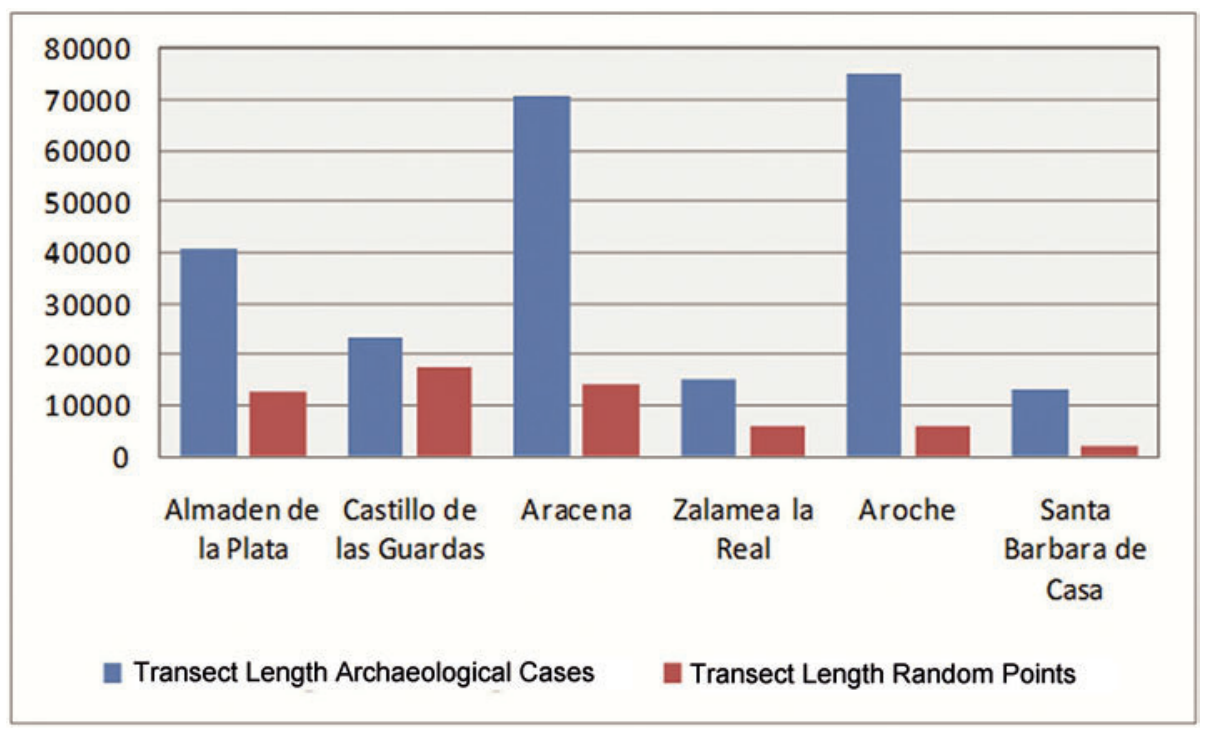

Fig. 9 | Comparison between the lengths $(\mathrm{m})$ of the path segments from which the monuments or random points are visible.

Middle Range: $\alpha$ from $0.08^{\circ}$ to $0.3^{\circ}$. The monument can still be a reference point but is likely to appear more integrated into the wider landscape.

Large Range: $\alpha$ less than $0.08^{\circ}$. Although the monument may still be visible, it may start to fade into the surroundings. How easily it is recognized will probably depend on the actual shape of the monument or its contrast with the surrounding landscape.

In this sense, the maximum distance in the Short Range will be 478 . o I $\mathrm{m}$, in the case of the Middle Range it will be I,798.56 $\mathrm{m}$ and the limit of the Large Range will be defined by the distance established in the actual visibility analysis, which in this case is 3,000 $\mathrm{m}$.

\section{Results}

The results obtained from the statistical tests were very interesting in terms of observable patterns. From the six tests (one per group) conducted to investigate if megalithic monuments are randomly distributed with respect to their visibility from natural corridors, in three cases the null hypothesis was rejected at a significance level of 0.05 . While the groups in this situation were Almadén de la Plata (Group I) (25 monuments), Castillo de las Guardas (Group 2) (22 monuments) and Aroche (Group 5) (I8 monuments), whereas for Aracena (Group 3) (I6 monuments), Zalamea la Real (Group 4) (29 monuments) and Santa Bárbara de Casa (Group 6) (9 monuments), the null hypothesis could not be rejected. 
Although this appears at first sight to be an inconclusive result, delving into the results of the analysis we see that in all cases the megalithic monuments are on average more visible from the natural corridors than from random points in the landscape. This is demonstrated by comparing the visibility of the random sample and the monuments, where it can be observed that the length of segments from which they are visible is more extensive (Figure 9).

Even in the groups where the null hypothesis could not be rejected, the megalithic monuments were visible for longer sections than the random points. In the case of the Aracena group, while the total length of segments from which the random points are visible is $13,951.293 \mathrm{~m}$, the total length from which the megalithic monuments are visible is $70,550.484 \mathrm{~m}$. In the case of Zalamea la Real, the same phenomenon is observed, where the total length of the corridors from which the random points are visible is $6,040.666 \mathrm{~m}$, and I3,303.II4 in the case of the megalithic monuments. For Santa Bárbara de Casa the difference is also large, with a total length of 2,120.460 $\mathrm{m}$ for the visibility of random points, and I3,184.366 $\mathrm{m}$ for the monuments (Figure I0). This means that in general there is a larger visual exposure of the megalithic monuments along the natural corridors than other points in the landscape, even if we cannot say that the relationship is statistically significant at a 0.05 level.

This is obviously connected to the already proved spatial relationship between monuments and corridors and it could be thought of as an indication of their use as waypoints. However, if the megalithic monuments were acting as such for travellers who were not necessarily familiar with the landscape, and their locations were intended as terrestrial guidance, they should have acted as a relatively regular system. In other words, along the route at least one of the monuments would be visible at all, or almost all, times. This is related to the way terrestrial navigation is accomplished, where in order to follow a route we need to be able to connect spatially the diverse markers on the route. In order to test this, the visual exposure to the megalithic monuments along the routes was graphed, measuring for how long segments have a visual exposure to the monuments in each group. For this, the number of monuments that are visible each $10 \mathrm{~m}$ along a path was recorded, generating a visual graphic of its exposure to them (Figures II and I2).

Although in this chapter only some examples are presented, it can be noted that, in most of the groups, visual exposure to the monuments along some of the routes was detected. Nonetheless, there tend to be considerable "gaps" in the visual exposure from routes. This contradicts the notion of a visual network. However, a positive outcome is that the analysis allowed the identification of sections on the pathways that seem to have prompted the visibility of a large number of monuments. This can be regarded as significant in terms of the visual impact that megaliths and other prehistoric monuments (such as Bronze Age stelae) may have had within the landscape (García Sanjuán et al. 2006; García Sanjuán 20II), and the establishment of symbolic places possibly related to specific groups. In this manner, the continuous visibility of these monuments from the paths emphasizes 

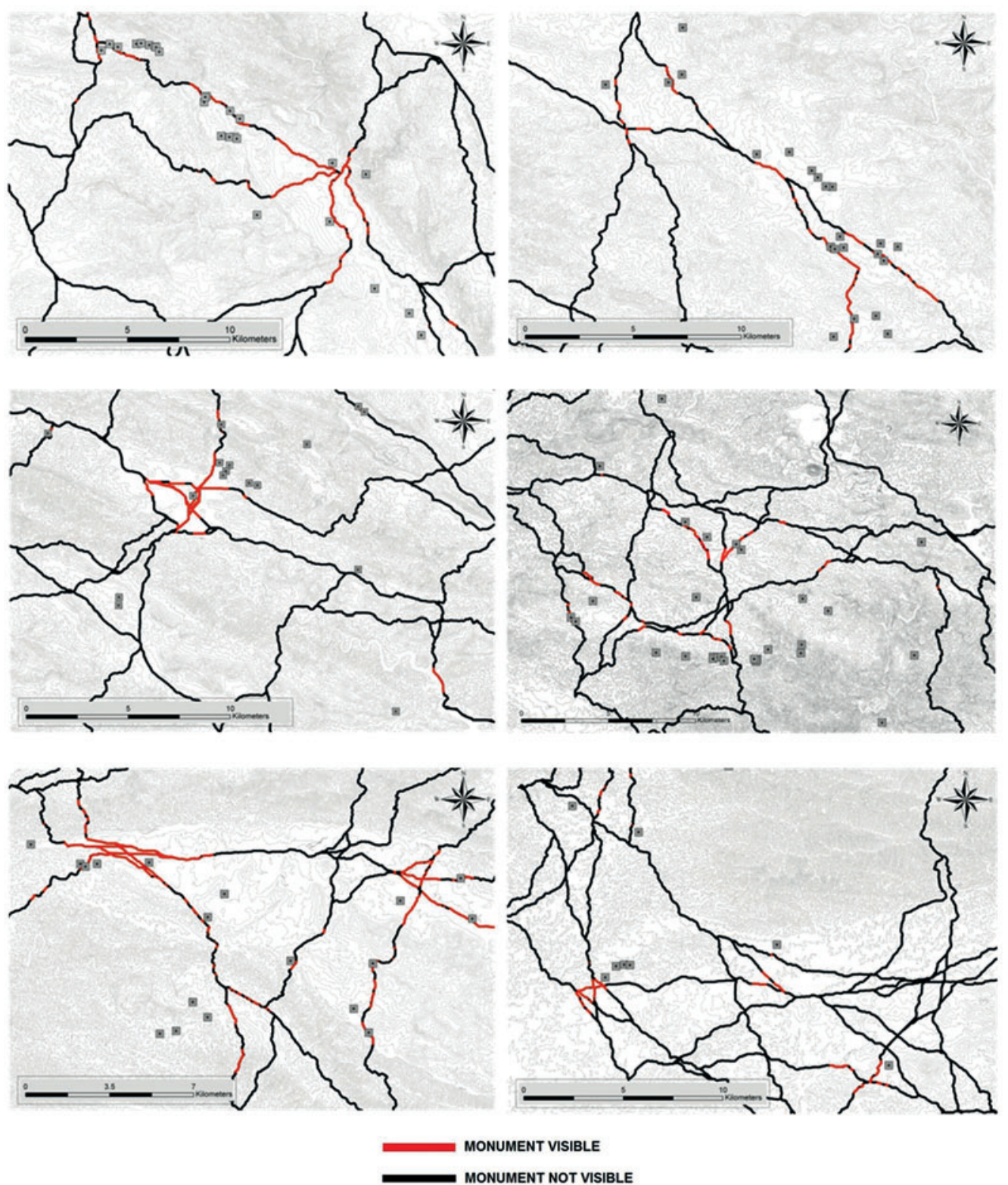

Fig. 10 | Segments of the natural corridors from which one or more megalithic monuments are visible: a) Almadén de la Plata, b) Castillo de las Guardas, c) Aracena, d) Zalamea la Real, e) Aroche and f) Santa Bárbara de Casa. 

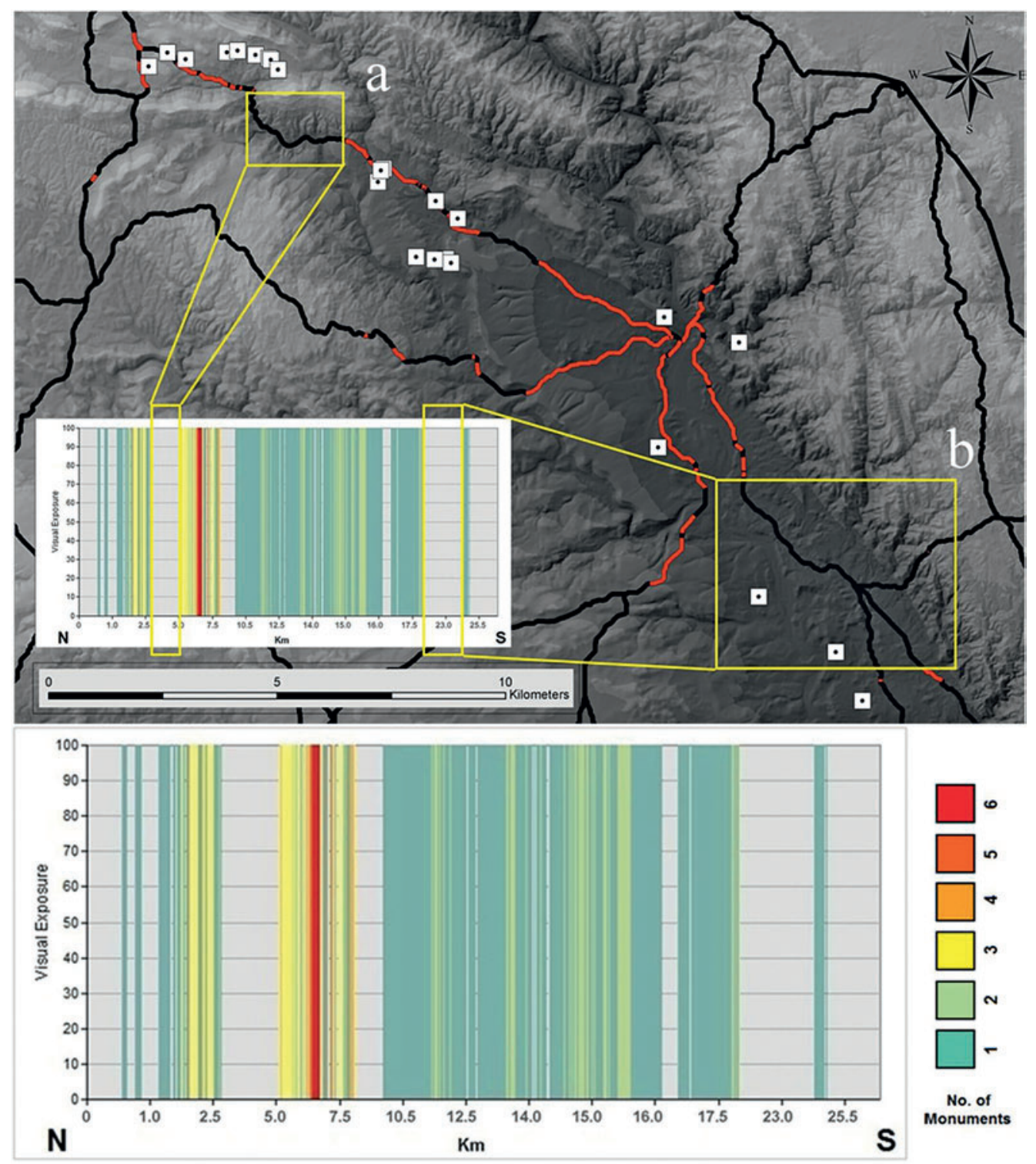

No. of

Monuments

Fig. 1 | Cumulative visual exposure to megalithic monuments from natural corridors of Almadén de la Plata and the longest gaps in visual exposure between (a) the San Bartolomé and Palacio groups and (b) El Chaparral III and Dolmen del Esparragal. 

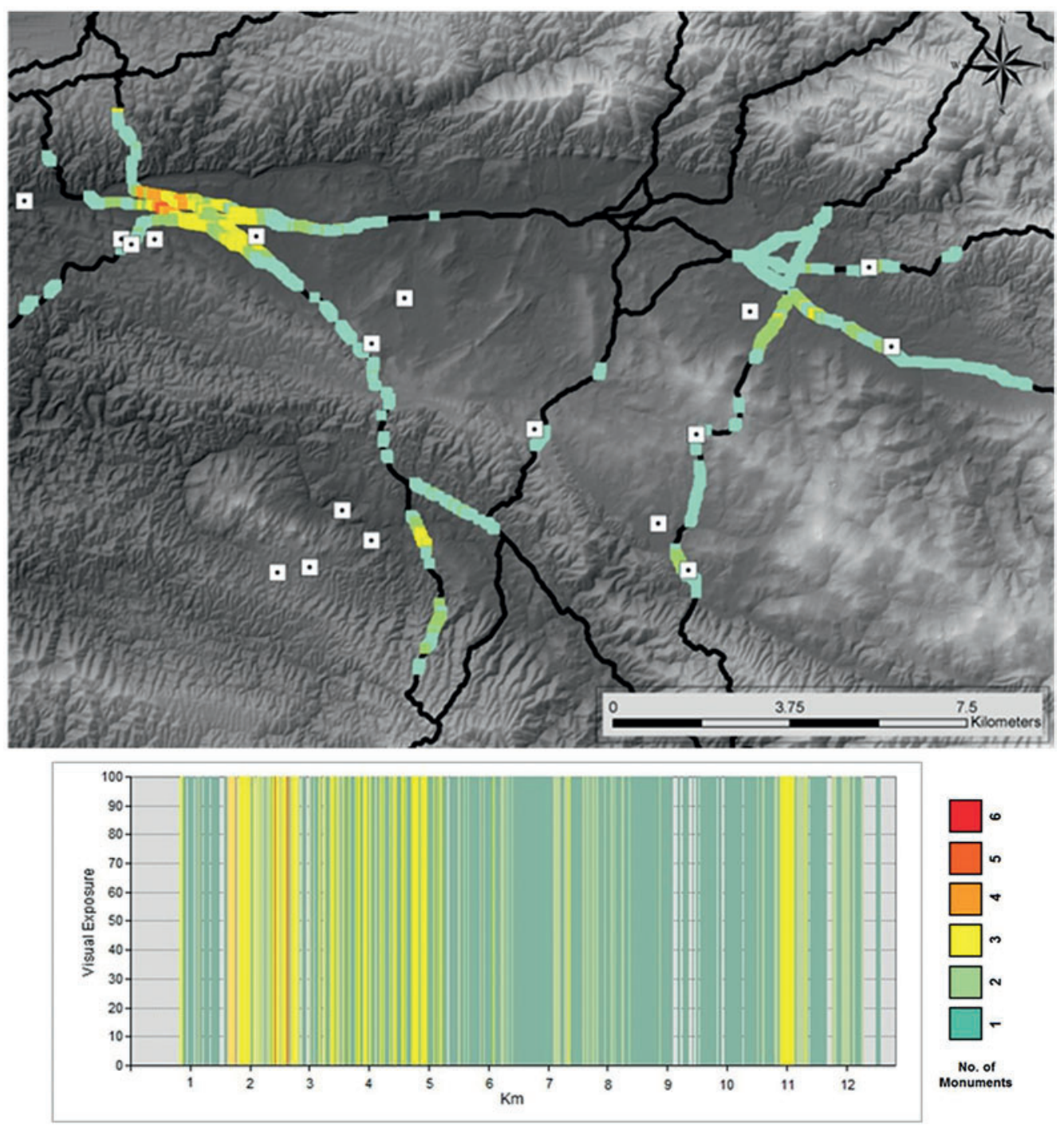

Fig. 12 a) Segments in the natural corridors from which the megaliths are visible. b) Cumulative visual exposure to all megalithic monuments from natural corridors of Aroche. 

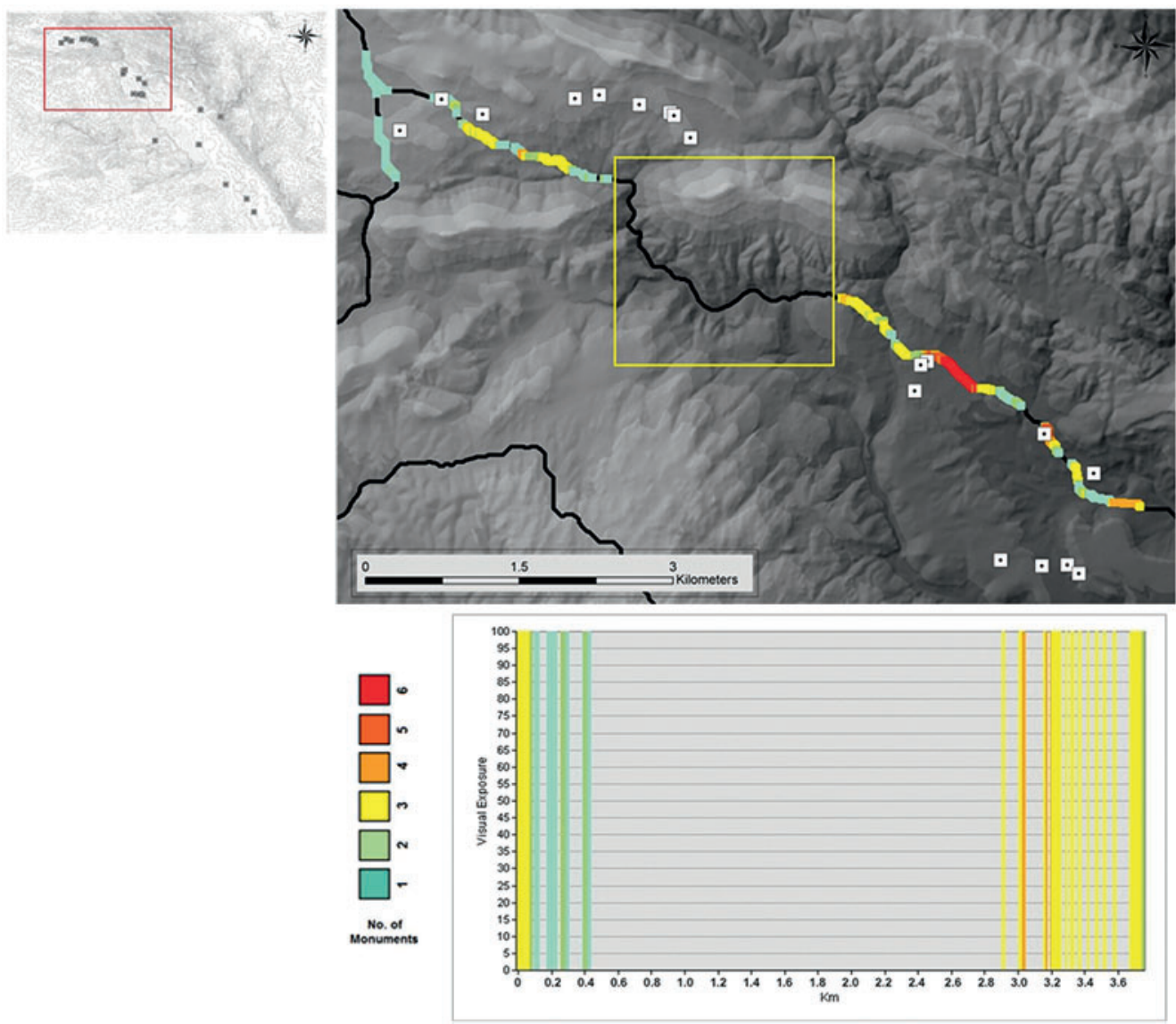

Fig. 13 | Visual exposure of the megalithic groups of San Bartolomé and Dolmen de Palacio III from a segment of the natural corridor that runs along the transhumance route of Cordel del Pedroso.

their significance in terms of the creation of a funerary and symbolic landscape, where the visual accessibility of the monuments seem to have had great importance. This is supported by the results obtained by the statistical test already mentioned, which was conducted in order to investigate directional viewsheds. This analysis showed a significant relationship in most of the groups and that the majority of the dominant directions in the fields of view from monuments are related to a natural corridor or to a transhumance route (Figure I3). However, in terms of terrestrial navigation this could be interpreted in a different way. Although the megaliths in many cases are quite well distributed along the main corridors, many of them are clustered (Figure I3). Whether or not they are all contemporary, in neither case would it have been necessary to have several waypoints very close to each other if one of them was already visible from the corridor. In this manner, the adjacent location of the monuments is perhaps more related to a symbolic recognition of particular 


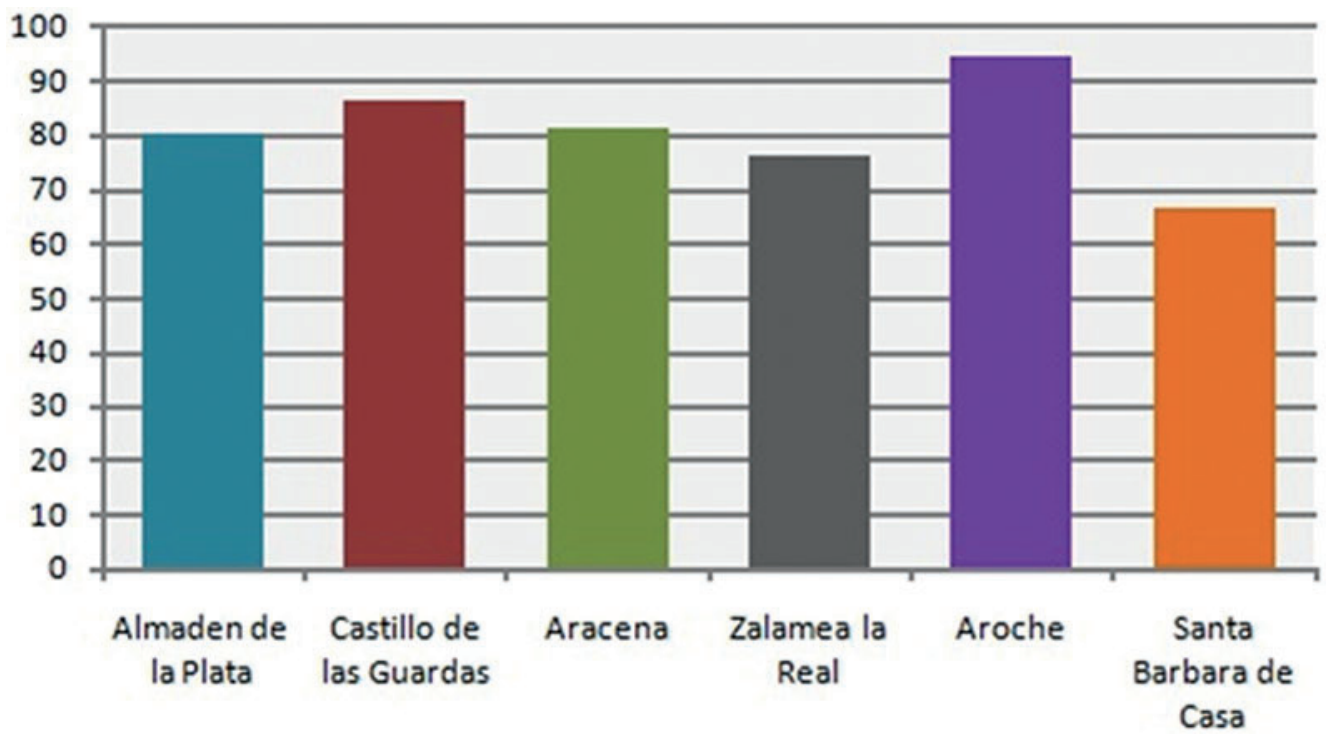

Fig. 14 | Percentages per group of monuments that present a field of view with a dominant direction towards natural corridors.

places that acted as mnemonic markers for a number of groups, families or households, but not necessarily as waypoints.

Regarding the directional viewsheds, the general results were very interesting. Although in the first statistical analysis the relationship between general visibilities and the corridors in some of the groups could not be confirmed, the tests exploring the specific dominant directions in the fields of view of the monuments and their possible connection to corridors was statistically significant. This was the case in all groups with the exception of Santa Bárbara de Casa, where the test could not be carried out due to the small sample. A closer look at the individual results of this analysis confirms that in 5 of the 6 groups, more than $80 \%$ of the monuments exhibit fields of view in which the dominant directions are the ones that coincide with the natural corridors. Again, this is the case in all groups with the exception of Santa Bárbara de Casa, where the dominant directions are related to a natural corridor in only $66.66 \%$ of the monuments. While in Almadén de la Plata $80 \%$ of the megaliths present a relationship between predominant direction of view and corridors, for Castillo de las Guardas the figure is $86.36 \%$. In the case of Aracena the coincidence is $8 \mathrm{I} .25 \%$, for $\mathrm{Za}$ lamea la Real $80.95 \%$ and for Aroche $94.44 \%$ (Figure I4). These results point to the idea that, towards the Copper Age, the majority of the monuments within the sierra were built in locations from which natural corridors were visible. In fact, the results suggest that locations with a dominant view oriented to the corridors were preferred (Figure 15).

The modified Higuchi viewsheds reaffirmed the observations made previously, which pointed to a close visual relationship between monuments and corridors. It was of great in- 

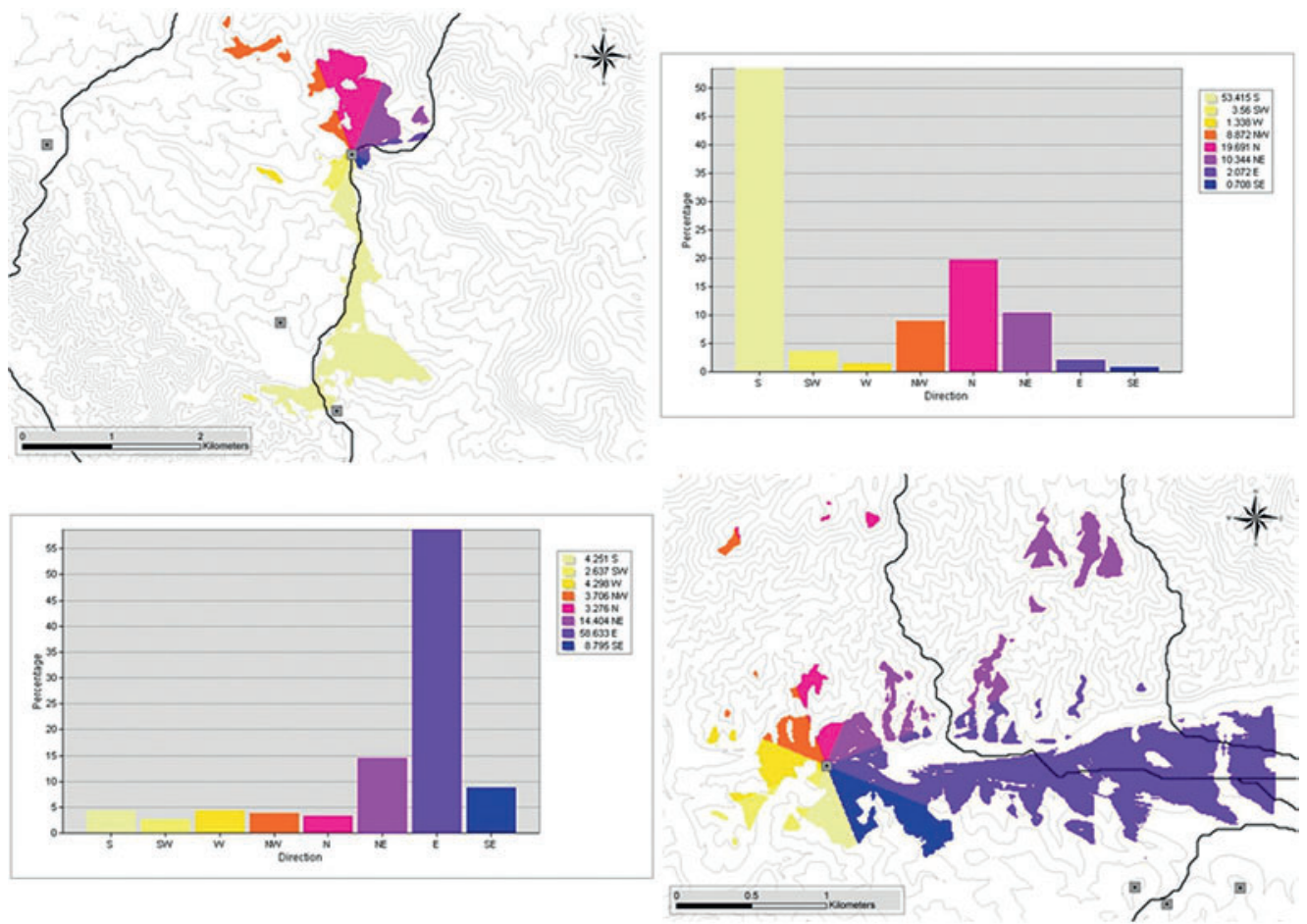

Fig. 15 | Notice the coincidence between the dominant view direction of La Portilla (above) and Pasada del Abad in Aroche (below) with natural corridors.

terest to observe that the majority of the natural corridors fall in what we defined as a visual Middle Range (Figure I6). This seems to be consistent also with the visibility of historical routes, where, as in the previous case, the majority also fall in this range. Nevertheless, there seems to be a closer relationship between monuments and natural corridors than between monuments and historical routes (Figure I7). It is also worth mentioning that, although the number of natural corridors that fall in the visual Short Range is lower, in the majority of the groups there is still a very high coincidence between corridors and monuments where in up to $66.66 \%$ of the cases a natural corridor passes through the shortest range. This is relevant because a close visual proximity to the corridors implies a greater chance of monuments being visible, and therefore that they could be used as waypoints. However, a more consistent relation to the Middle and Long Ranges is observed, and this seems to suggest that there was an intentional relationship of proximity between them. This is also supported by the fact that even in flatter and broader landscapes like the Viar Valley (Almadén de la Plata, Group I) in which the options about where to walk are very wide, late prehistoric societies of this region chose to locate their monuments at close visual ranges to natural corridors. As said, this is observed in the majority of the cases and this relationship could be associated with the way herding trips were conducted and the way that, 

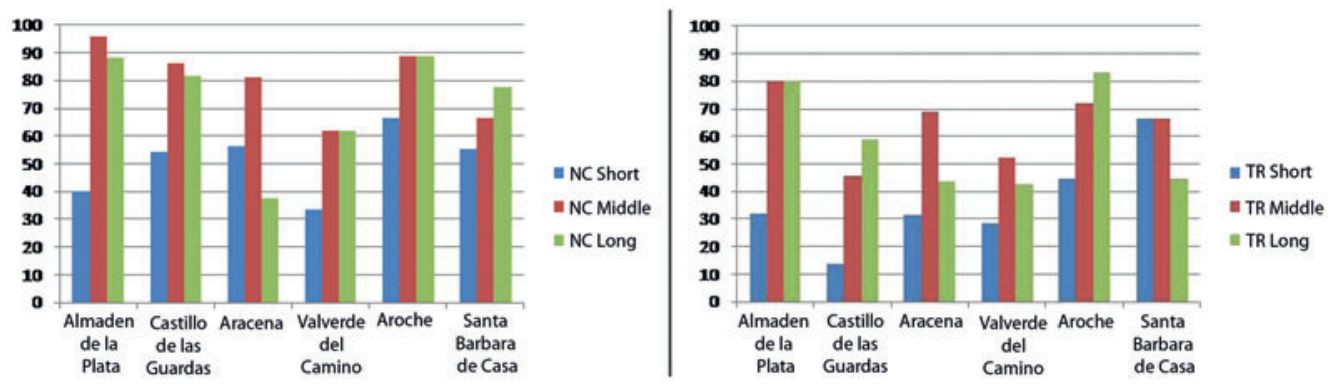

Fig. 16 | Results of the Higuchi Viewsheds: a) Percentage of coincidence between natural corridors and visual distance ranges established and b) between historical transhumance routes and visual distance ranges.

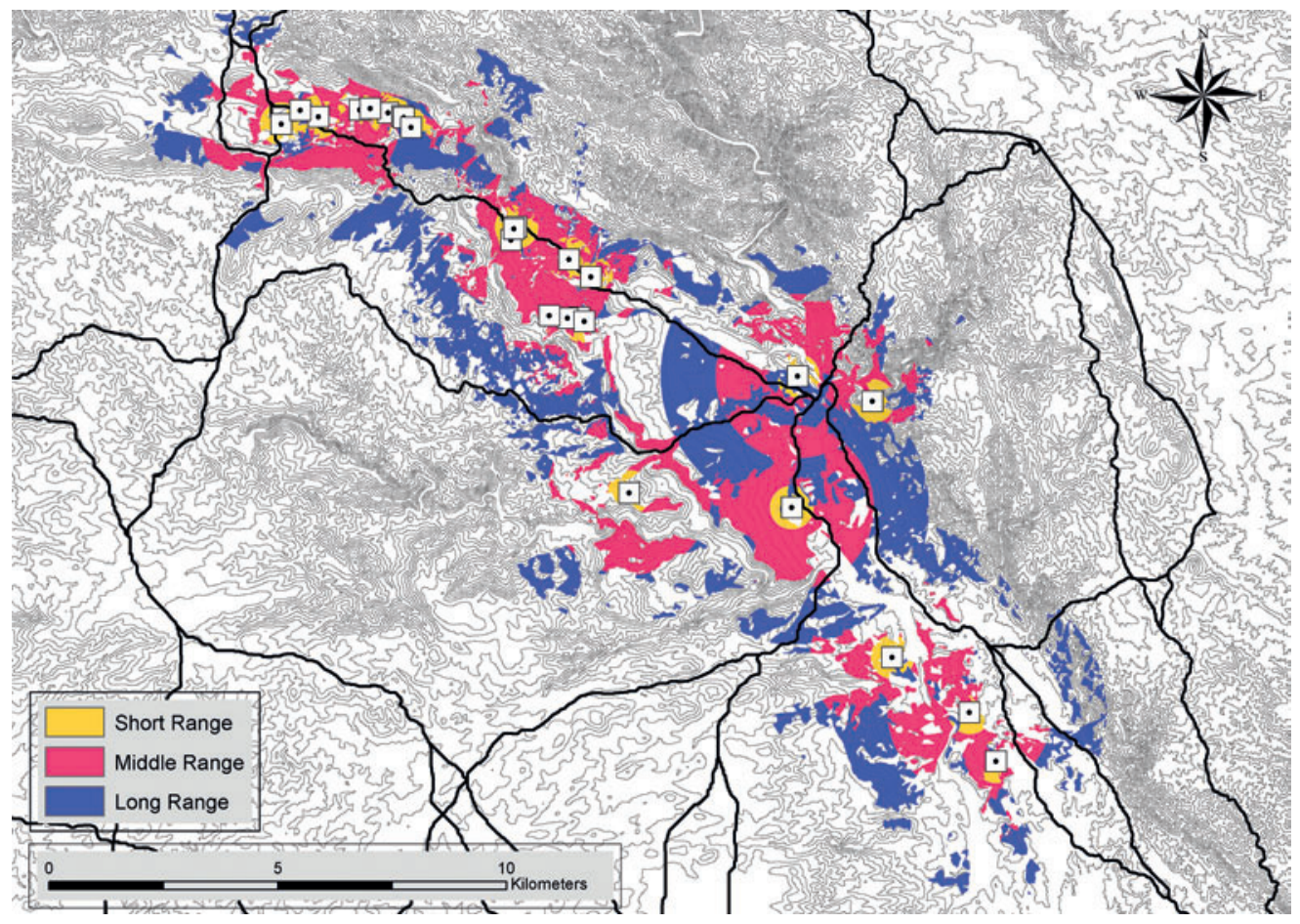

Fig. 17 | Notice the coincidence between the dominant view direction of La Portilla (above) and Pasada del Abad in Aroche (below) with natural corridors. 
as places to visit during these journeys, the visibility of symbolic places in relation to corridors became important. It is very interesting to note that other research (Galán Domingo / Ruíz-Galvez 200I; Murrieta-Flores 20I2a; 20I3) has suggested that megaliths may have also served as landmarks at fords and mountain passes, and this observation seems to be strengthened by this analysis.

\section{Conclusion}

The assessment of the use of megaliths as waypoints has proved a difficult task as the models are relatively simple and the variables to take into account are complex. However, it can be said that the experiments were successful in the identification of a series of interesting patterns. The relationships observed between dominant directions in the fields of view and corridors in the majority of the groups, and the high coincidence between general visibilities and pathways, point to the idea that monuments were effective landscape markers. However, they seem not to have been built with a focus on terrestrial navigation. It is certain that there is a visual relationship between the monuments and natural corridors, and people familiar with this landscape may have been able to locate them easily. Although there is no single corridor where monuments could be regarded as part of a "complete" visual system in terms of continuous visibility, it must be also taken into account that many other features in the landscape may have acted as intermediate waypoints, such as characteristic topographical features or trees. In this manner, it is acknowledged that, with information such as verbal accounts, foreigners too may on some occasions have been able to use them as points of reference while navigating through the landscape. In those terms, they may have been used as waypoints too.

What seems to be certain is that the monuments marked vistas for people moving along the corridors. This seems to be confirmed by the fact that the megaliths are seen more often from the corridors than are other points in the landscape, and because the lengths of the segments from which they are visible within the paths are considerably larger. This outcome is reinforced by the results from the directional viewsheds. The fact that the dominant directions in the fields of view of the megaliths are the ones oriented towards the natural corridors suggests that the visibility of the monuments from them and the other way around was regarded as important in some sense. In this manner, the reason why these two features were visually and spatially connected could lie in the symbolic role that they probably played within pastoral orbits (Murrieta-Flores 20I2a; 20I3). While carrying out these cyclical movements, mobile herding societies visit places they regard as significant in terms of symbolism and memory. These places are normally related to their seasonal cycles, and therefore they are located within their areas of movement. Some of them are visited through several generations and different groups may also have places in common where they can meet to exchange news, celebrate festivities, conduct commerce or 
marriages or simply spend time with each other. Furthermore, the link between monuments and movement may be connected to the idea of permanence, helping to mark the pastoral orbits of different groups. In this sense, the association of monuments and corridors may find its explanation in the symbolic meaning of these sites and their use as landscape markers over generations. The possible meaning of the megaliths as the "houses" of the ancestors could have played an important role in the visits established during the pastoral circuits, where the long use of sites like Palacio III in Almadén de la Plata or Valdelinares in Aracena may constitute testimony of this.

Although it is clear that distinctive locations with particular characteristics were chosen to build the megaliths in this region, it is also interesting to observe that in some cases they are close also to the sources of material from which the orthostats that compose them were taken. This is the case with monuments like Valdelinares in Aracena (Romero Bomba 200I, 377). There seems thus to be a component of economy and practicality in the choice of these places, but the importance of this factor in determining the selection of the sites can only be explored further through detailed study of the sources of building materials. In addition, it could be said that in many cases the monuments seem to be located near rivers and fords. While as part of a herding itinerary these locations would have many convenient qualities in marking sources of water and river crossings, there could also be a symbolic, where the monument commemorates not only ancestors, but also the importance of movement in their way of life. It is of great interest to observe that while settlements seem to be seasonal, the only permanent features are precisely these monuments, which, being located along natural corridors, could have celebrated the cycles of life and the temporal character of their actions, in which movement knit together all meanings and representations.

Therefore, although monuments may not have acted as waypoints in the same manner as the Roman miliarium did, it is very possible that they acted as landmarks in the same way that other, later societies would recognize the architecture of their own times. Just as a pilgrim knows her parish and could identify a Christian church even if far away from home, it is possible that prehistoric communities utilized monuments as markers of important places within their landscape and, even if they may have occasionally served as a point of reference for terrestrial navigation, it is unlikely that all of them functioned as such, so as to form waypoints within travel "itineraries."

The location of important symbolic places throughout cultures and times has usually been attached to particular events, beliefs or social memories. Although nowadays the specific meanings of megaliths escape us, it is interesting to observe that we can still recognize in their locations aspects that seem to have been of importance. The constant observation of a spatial relationship between megalithic monuments and natural corridors could be something specific to the mountain environment of Sierra Morena. However, this connection may be related to the dynamics of these societies' daily life. It is possible that hunting and herding itineraries were formed over time, where contacts with different groups made 
possible a "unified" idea in the symbolism of a megalithic landscape, which at the same time took a distinctive and particular character in each region. This seems to be the case in the western Sierra Morena, where the megalithic phenomenon as well as other archaeological evidence is testimony of the contact between regions. Nevertheless, these contacts seem not to be very extensive and the general day-to-day dynamics probably had a more local nature. This does not mean that they did not actually have extensive contacts with other regions. Several stone tools and green stones such as variscite have been found in other Copper Age sites and they may have their origin in western Sierra Morena (Linares Catela et al. 2010; Linares Catela / Odriozola Lloret 20II).

As said before, the differences observed in settlement patterns, as well as in sizes and styles of construction of the megalithic monuments between regions such as the Guadalquivir Valley and Sierra Morena, seem to support the idea not only of a differentiation in demographic numbers and access to resources, but possibly also in ideology and the construction of a symbolic landscape. It even seems possible to differentiate between regions within western Sierra Morena. However, what they may have in common is that their megaliths were built by groups formed from several families and the locations selected were always near to natural corridors and possibly related to their herding itineraries. In this manner, during hunting and herding journeys, the places once regarded as special were chosen to become sites with an enduring character within social memory, where the megaliths would effectively become a physically permanent station among different groups, marking the space symbolically.

Later, towards the Bronze Age, the dynamics seem to change with the establishment of more permanent settlements like El Trastejón (Aracena). The de-monumentalization of funerary practices and the change to individual tombs marked a very significant transformation of the monuments in terms of social meaning. Nevertheless, in terms of cosmology, these structures and places were still regarded as important in western Sierra Morena. This is evident in monuments like Valdelinares (Aracena) which, due to its dimensions and construction system, could be regarded as related to a later period during the Copper Age, and closer to the megalithic cists. The reuse through many generations of these monuments and sites, like Valdelinares, Palacio III (Almadén de la Plata), El Pozuelo (Zalamea la Real), El Trastejón and La Papúa (Aracena), are testimony of their role as markers and sites of power within the landscape. However, although there seems to be continuity in the funerary patterns, where monuments were reused or new ones were still located very near to natural corridors, this coincidence decreased. Gradually, groups transformed into societies where individuals had more weight, a phenomenon that emerged along with an increasing social inequality. The apparent establishment of a stronger mobile tradition in terms of extended networks, and probably the increase in commerce and exchange, seem to be the reasons why we can observe a closer and growing spatial relationship between settlements and corridors towards the Early and the Late Bronze Age. With the presence of permanent settlements and the development of a society with more social inequality, both settlement 
and funerary spatial patterns changed. The way of carrying out the pastoral orbit probably did not involve families anymore, but one or a few members, and, while the funerary sites were possibly part of the itineraries, the settlements seem to have taken on a more important role within them (Murrieta-Flores 2013).

\section{References}

Andrés Rupérez, M.T. (1999)

"Los caminos y los sepulcros megalíticos", in: M.A. Magallón Botaya (ed.), Caminos y comunicaciones en Aragón, Zaragoza: Institución Fernando el Católico.

Branting, S.A. (2004)

Iron Age Pedestrians at Kerkenes Dag: An Archaeological GIS-T Approach to Movement and Transportation, The State University of New York, Buffalo.

Bueno Ramírez, P. / Piñón, F. / Prados, L. (1985)

"Excavaciones en el Collado de Sejós (Valle de Polaciones, Santander). Campaña I982", in: Noticiario Arqueológico Hispanico 22, 27-53.

Bueno Ramírez, P. (1987)

"El megalitismo en Extremadura. Estado de la cuestión", in: El megalitismo en la Península Iberica, IbéricQll, 73-84.

Chapman, R. (1979)

"Transhumance and Megalithic Tombs in Iberia", in: Antiquity 53, I50-I52.

Chapman, R. (198I)

“The Emergence of Formal Disposal Areas and the 'Problem' of Megalithic Tombs in Prehistoric Europe”, in: R. Chapman / I. Kinnes / K. Randsborg (eds.), The Archaeology of Death, Cambridge, 7I-8I.

Criado Boado, F. / Fábregas Valcarce, R. / Vaquero Lastres, J. (I990-I99I)

"Concentraciones de túmulos y vías naturales de acceso al interior de Galicia", in: Portugalia II-I2, 27-38.

Criado Boado, F. / Fabregas Valcarce, R. / Vaquero Lastres, J. (1994)

"Regional Patterning among the Megaliths of Galicia (NW Spain)", Oxford Journal of Archaeology I3(I), 33-47.

Criado Boado, F. (1993)

"Visibilidad e interpretación del registro arqueológico", in: Trabajos de Prehistoria 50, 39-56.

Eguileta Franco, J.M. (1994)

Megalitismo e Calcolítico na Baixa Limia galega, Santiago de Compostela.

Ehlers, E. / Kreutzmann, H. (2000)

"High Mountain Ecology and Economy. Potential and Constraints", in: E. Ehlers / H. Kreutzmann (eds.), High Mountain Pastoralism in Northern Pakistan, Stuttgart, 9-36. 
Fábrega Álvarez, P. (2006)

"Moving without Destination. A Theoretical, GIS based Determination of Routes (Optimal Accumulation Model of Movement from a Given Origin)", in: Archaeological Computing Newsletter 64, 7-II.

Fábrega Álvarez, P. / Parcero Oubiña, C. (2007)

"Proposals for an Archaeological Analysis of Movement and Pathways", in: Archeologia e Calcolatori I8, I2I-I4O.

Fairén Jiménez, S. (2004)

“¿Se hace camino al andar? Influencia de las variables medioambientales y culturales en el cálculo de caminos óptimos mediante SIG”, in: Trabajos de Prehistoria 6I(2), 25-40.

Fiz, I. / Orengo, H. A. (2008)

"Simulating Communication Routes in Mediterranean Alluvial Plains", in: A. Posluschny / K. Lambers / I. Herzog (eds.), Layers of Perception. Proceedings of the 35th International Conference on Computer Applications and Quantitative Methods in Archaeology (CAA), Berlin, Germany, April 2-6 2007, Bonn, 316-32I.

Fleming, A. (1973)

"Tombs for the Living", Man 8(2), I77-193.

Galán Domingo, E. (1993)

Estelas, paisaje y territorio en el Bronce final del Suroeste de la Península Ibérica, Complutum (3), I5-IIO.

Galán Domingo, E. / Martín Bravo, A.M. (I991-I992)

"Megalitísmo y zonas de paso en la cuenca extremeña del Tajo", Zephyrus 44-45, I93-205.

Galán Domingo, E. / Ruíz-Gálvez, M. (200I)

"Rutas ganaderas, transterminancia y caminos antiguos. El caso del Occidente Peninsular entre el Calcolítico y la Edad del Hierro", in: J. Gómez-Pantoja (ed.), Los rebaños de Gerión. Pastores $y$ transhumancia en Iberia antigua $y$ medieval, Madrid, 279-3II.

García Sanjuán, L. / Vargas Durán, M.A. (2002)

"Prospecciones de superficie en Almadén de la Plata (Sevilla)", in: Anuario Arqueológico de Andalucía I991, 258-270.

García Sanjuán, L. / Vargas Duran, M. / Wheatley, D. (2002)

Zona de afección del Embalse de Los Melonares (Sevilla). Prospección Arqueológica Superficial Y Delimitación de Elementos de Carácter Patrimonial. Campañas Agosto-Septiembre 2001 y Abril 2002. Informe, Universidad de Sevilla, Sevilla.

García Sanjuán, L. / Vargas Durán, M.A. / Wheatley, D. (2004)

"Prospecciones de superficie en la zona de afección del embalse de Los Melonares (Almadén de la Plata, El Pedroso y Castilblanco de los Arroyos, Sevilla)", in: Anuario Arqueológico de Andalucía 200I, 3 (Actividades de Urgencia), 962-972.

García Sanjuán, L. / Metcalfe-Wood, S. / Rivera Jiménez, T. / Wheatley, D. (2006)

"Análisis de pautas de visibilidad en la distribución de monumentos megalíticos de Sierra Morena Occidental”, in: I. Grau Mira (ed.), La aplicación de los SIG a la Arqueología del Paisaje, Alicante, I8I-200. 
García Sanjuán, L. / Wheatley, D. / Fabrega Alvarez, P. / Hernandez Arnedo, M. / Polvorinos del Rio, A. (2006)

"Las Estelas de Guerrero de Almadén de la Plata (Sevilla). Morfología, Tecnología y Contexto", in: Trabajos de Prehistoria 63(2), I35-I52.

García Sanjuán, L. (20II)

"The Warrior Stelae of the Iberian South-west: Symbols of Power in Ancestral Landscapes", in: T. Moore / L. Armada Pita (eds.), Atlantic Europe in the First Millennium BC: Crossing the Divide, Oxford, 534-557.

Golledge, R.G. (1999)

Wayfinding Behavior: Cognitive Mapping and Other Spatial Processes, Baltimore.

Gómez Vila, J. (2005)

"Caminos y túmulos. Aproximación al estudio de los caminos megalíticos en el noroeste peninsular", in: P. Arias Cabal / Roberto Ontañon Peredo / Cristina García-Monco Piñero (eds.), Actas del III Congreso del Neolítico en la Península Ibérica, Santander, 405-4I2.

Higuchi, T. (1983)

Visual and Spatial Structure of Landscapes, Cambridge, MA.

Hurtado Pérez, V. / García Sanjuán, L. / Hunt Ortiz, M. A. (eds.) (20II)

El Asentamiento de El Trastejón (Huelva). Investigaciones en el Marco de los Procesos Sociales y Culturales en la Edad del Bronce en el Suroeste de la Península Ibérica, Sevilla.

Linares Catela, J.A. / Odriozola Lloret, C. / Hurtado Pérez, V. (20I0)

"Variscite Source and Source Analysis: Testing Assumptions at Pico Centeno (Encinasola, Spain)", in: Journal of Archaeological Science 37, 3I46-3157.

Linares Catela, J.A. / Odriozola Lloret, C. (20II)

"Cuentas de collar de variscita y otras piedras verdes en tumbas megalíticas del Suroeste de la Península Ibérica. Cuestiones acerca de su producción, circulación y presencia en contextos funerarios", in: L.S. García Sanjuán / C. Scarre / D. Wheatley (eds.), Exploring Time and Matter in Prehistoric Monuments: Absolute Chronology and Rare Rocks in European Megaliths. Proceedings of the 2nd EMSG Meeting (Seville, November 2008), Seville, 335-369.

Llobera, M. (2000)

"Understanding Movement: A Pilot Model towards the Sociology of Movement", in: G. Lock (ed.), Beyond the Map. Archaeology and Spatial Technologies, Amsterdam.

Llobera, M. (2007b)

"Reconstructing Visual Landscapes", in: World Archaeology 39(I), 5I-69.

Llobera, M. / Sluckin, T. J. (2007)

"Zigzagging: Theoretical Insights on Climbing Strategies", in: Journal of Theoretical Archaeology 249, 206-2I7.

Mlekuž, D. (20I0)

"Time Geography, GIS and Archaeology", Paper Presented at the 38th Conference on Computer Applications and Quantitative Methods in Archaeology, April 20I0, Granada, Spain. 
Moran, P. (1950)

Notes on Continuous Stochastic Phenomena. Biometrika, 37,I7-23.

Murrieta Flores, P.A. (2007)

"Mobility, Transhumance and Prehistoric Landscape. A GIS Approach to the Archaeological Landscape of Almadén de la Plata in Andalucía, Spain", masters thesis, University of Southampton.

Murrieta-Flores, P. (2010)

"Travelling in a Prehistoric Landscape: Exploring the Influences that Shaped Human Movement”, in: B. Frischer / J. Webb Crawford / D. Koller (eds.), Making History Interactive. Computer Applications and Quantitative Methods in Archaeology (CAA). Proceedings of the 37th International Conference, March 22-26, 2009, Williamsburg, Virginia, United States of America. Oxford, 258-276.

Murrieta-Flores, P. (20I2a)

"Understanding Movement during Late Prehistory through Spatial Technologies: The Role of Natural Areas of Transit in South-Western Iberia", in: Trabajos de Prehistoria 69(I), II4-I33.

\section{Murrieta Flores, P. (20I2b)}

"Travelling through Past Landscapes. Analysing the Dynamics of Movement during Late Prehistory in Southern Iberia with Spatial Technologies", doctoral thesis, University of Southampton.

Murrieta-Flores, P. (2013)

"Space and Temporality in Herding Societies: Exploring Dynamics of Movement during Iberian Late Prehistory", in: S. Souvatzi/ A. Hadji (eds.), Space and Time in Mediterranean Prehistory, London, I96-213.

Murrieta-Flores, P. / Wheatley, D. / García Sanjuan, L. (20ı1a)

"Movilidad, trashumancia y paisaje prehistórico: Estudio del paisaje arqueológico de Almadén de la Plata, Andalucía a través de un SIG", in: V. Mayoral Herrera / S. Celestino Pérez (eds.), Sistemas de Información Geográfica Y Análisis Arqueológico del Territorio, Actas del V Simposio Internacional de Arqueología de Mérida. Mérida, 7-Io de Noviembre de 2007. Mérida, $4 \mathrm{II}-423$.

Murrieta Flores, P. / Wheatley, D. / García Sanjuán, L. (20IIb)

"Antes de los mapas: Navegación y orientación terrestre en la Prehistoria Reciente Ibérica", in: PH: Boletín del Instituto Andaluz del Patrimonio Histórico I9(77), 85-88.

Ogburn, D.E. (2006)

"Assessing the Level of Visibility of Cultural Objects in Past Landscapes", in: Journal of Archaeological Science 33, 405-4I3.

Pellicer Catalán, M. / Hurtado Pérez, V. (I980)

El poblado metalúrgico de Chinflon (Zalamea la Real, Huelva), Sevilla.

Pérez Macías, J.A. (1987)

Carta arqueológica de los Picos de Aroche, Huelva. 
Pérez Macías, J.A. (1996b)

"El Cerro de las Abejas (Rosal de la Frontera, Huelva). La expresion de un territorio de la Edad del Cobre", in: I Jornadas Transfronterizas sobre La Contienda Hispano-Portuguesa (junio de 1995), Aroche, II3-II5.

\section{Pérez Macías, J.A. (1994)}

"El yacimiento Calcolítico del Cerro del Brueco. Propuesta para una secuencia de la Edad del Cobre en los Picos de Aroche", in: Arqueología en el Entorno del Bajo Guadiana, Huelva, II9-I48.

Pérez Macías, J.A. (1986)

"La ocupación prehistórica de la Peña de arias Montano (Alajár, Huelva)", in: Primeras Jornadas de Patrimonio de la Sierra de Huelva, 77-97.

Pérez Macías, J.A. (1996)

Metalurgia extractiva prerromana en Huelva, Huelva.

Pérez Macías, J.A. (2010)

"Un asentamiento del III Milenio A.C. en La Lapa (Encinasola, Huelva)", XXII Jornadas de la Comarca de la Sierra. Higuera de la Sierra (Huelva), Higuera de la Sierra, 269-285.

Piñón Varela, F. (1987)

"El Cabezo de los Vientos, La Zarcita (Santa Bárbara de Casa): un poblado Calcolítico fortificado en el NE de la provincia de Huelva. Campana de I985", in: Anuario Arqueológico de Andalucía I985, 2, 272-278.

Piñón Varela, F. (1988)

"El 'Grupo de Aroche': sepulcros de cámara poligonal y corredor en la Sierra de Huelva”, in: II Jornadas de Patrimonio de la Sierra de Huelva, Cortegana, 237-277.

Renfrew, C. (1976)

"Megaliths, Territories and Populations", in: S.J. De Laet (ed.), Acculturation and Continuity in Atlantic Europe, Mainly during the Neolithic period and the Bronze Age, Bruges, I98-220.

Romero Bomba, E. (200I)

"La intervención arqueológica en la estructura megalítica de Valdelinares (Zufre, Huelva)", in: Anuario arqueológico de Andalucía I997, 3, 376-383.

Saxe, A. (1970)

"Social Dimensions of Mortuary Practices", unpublished doctoral dissertation, University of Michigan, Ann Arbor.

Villoch Vázquez, V. (200I)

"El emplazamiento tumular como estrategia de configuracion del espacio social. Galicia en la prehistoria reciente", in: Complutum I2, 33-49.

Walker, M.J. (1983)

"Laying a Mega-myth: Dolmens and Drovers in Prehistoric Spain", World Archaeology I5(I: Transhumance and Pastoralism), 37-50. 
Wheatley, D. (1995)

"Cumulative Viewshed Analysis: A GIS-based Method for Investigating Intervisibility, and its Archaeological Application", in: G. Lock, and Z. Stancic (eds.), Archaeology and GIS: A European Perspective, London.

Wheatley, D. / Gillings, M. (2002)

Spatial Technology and Archaeology. The Archaeological Applications of GIS, London.

Wheatley, D.W. / García Sanjuán, L. / Murrieta Flores, P. / Márquez Pérez, J. (20I0)

"The Megalithic Phenomenon in Southern Spain: Approaching the Landscape Dimension", Oxford Journal of Archaeology 29(4), 387-405. 



\section{Abstracts}

\section{Mlekuž, Approaching past movement: time to move a little further?}

The paper discusses the ways to approach the past movement using GIS in archaeological landscape studies. Through movement we actively participate and create the world around us. By moving we bind things, places, persons together in a process of continuous becoming. Thus movement creates time, space and material world.

However, in archaeology we are dealing with the static, material residues of this past. The archaeological landscape is network of places, which were reproduced as 'collapsed acts' of persons moving and performing routines in space and time, themselves being changes in the process. They are time and movement materialised or 'fossilised' in the landscape. Paper presents some new tools and approaches for understanding past landscapes, especially tools for the analyses of proximity, mobility, accessibility and interaction. GIS procedures were developed to help us understand the limits time and space imposes in interaction between people and help us reveal deeper logic of social processes in landscape. Approaching past mobility also forces us to explicitly address the notion of time in GIS and archaeological landscape studies.

\section{Gary Lock, Mariza Kormann Rodrigues and John Pouncett (Oxford), Visibility and movement: towards a GIS-based integrated approach}

It is argued here that movement can only be fully experienced and, therefore, realistically modelled through integration with visibility. In this paper we explore a range of different approaches and techniques that investigate the characteristics of movement and visibility, the relationship between them and, importantly, how these are affected by changing scale. Using the ancient Ridgeway track in central England as a case-study, we first explore the idea of 'intentionality' within movement. This uses different sized windows of analysis to model 'looking ahead' and the idea of moving using waypoints as markers. In a related approach we develop Llobera's idea of landscape 'prominence' and introduce a new method, Fuzzy Cumulative Visibility Analysis (FCVA), which simulates a 'virtual walk' in the landscape by moving from cell to cell and calculating visibility in all directions. Some cells are seen more often than others in a continuously changing way and these changes can be expressed by a visibility index for each cell resulting in visibility gradients due to cumulative effects. This approach is novel in being applicable at a range of scales and is demonstrated through a case-study of Neolithic long barrows in central England. The approach to each barrow can be modelled in terms of visibility, distance and position to show interesting dif- 
ferences between basing these analyses on topography, prominence and FCVA. Building on this we continue with a re-assessment of the idea of 'Viewpaths' as first suggested by Lee and Stucky in 1998. This uses the notion that visibility is an actual 'cost' in influencing movement and is modelled by using forms and combinations of visibility indeces as cost surfaces for generating least cost paths, corridors and surfaces. Overall, this developing suite of approaches provides a much richer understanding of perceiving the landscape through movement and visibility than just viewsheds or cost paths.

\section{E. Fovet, K. Zakšek, Path modelling and settlement pattern}

This paper describes the contribution of path modelling to the ancient settlement pattern study over the long term. The path modelling methodology is a stimulating tool, which is complementary to the hierarchical approaches in the landscape archaeology since it contributes to the understanding of the spatial relation between archaeological sites. The existing methodology was enhanced by enlarging the set of path reconstitution parameters (visibility) and by modelling in two scales. The proposed model is based on parameters derived merely from the relief because its changes should be insignificant even over a long period time.

\section{P. Verhagen, S. Polla, I. Frommer, Finding Byzantine junctions with Steiner Trees}

The Byzantine road system in Cappadocia (Turkey) is known in reasonable detail. Reconstructions of the road system by Hild (I977) show the most probable location of the routes that were built and maintained by the imperial administration. Unlike the earlier Roman routes, these were not only built to establish fast connections between major cities; rather, they were intended to connect all administrative and religious centres in the area. A conspicuous element of this connecting network is the fact that road junctions are found in the countryside, without any corresponding traces of settlement. Least cost path models trying to connect the centres will inevitably fail to identify these junctions, since LCP modelling will only create routes between single sources and targets, and not find the optimal network solution to connect three or more destinations. Steiner trees are an appropriate mathematical solution to deal with this problem; however, applications in GIS are lacking up to now. In this paper we would like to present the preliminary results of a case study showing that it is technically possible to use Steiner trees in conjunction with cost surfaces. The modelling results seem promising, as the resulting connections are closer to the documented ones than those resulting from least cost path modelling. However, there are substantial unresolved issues regarding the implementation of this method in GIS. 


\section{P. Murrieta Flores, Walking through mountains and sacred monuments: insights to the role of natural areas of transit during Late Prehistory in South-Western Iberia}

Through time, societies have not only learned how to utilise resources from the environment, but they have also acquired specialised knowledge, adapting to it. Mountain regions are often very special environments due to their diversity, strategic significance and marginality. Mountain contexts are of great importance for people living within and neighbour areas due not only to their richness in natural resources and their great biodiversity, but also because of their peculiar socio-cultural dynamics, whose development has tended to be at the margins located often far away from the centres of political power. This marginality can be also extended to movement within these regions, where mountain ranges regularly constitute mighty obstacles due to their natural configuration, playing a central role in strategy, commerce and travelling. Movement in these environments is frequently localised and accommodated to the nature and steepness of the terrain. Travelling through natural passageways and optimal routes such as mountain passes and internal valleys is regular in these regions, and although the optimal employment of the landscape not always prime in human societies, in certain special conditions such as these, the search for optimality can have serious advantages. In the case of western Sierra Morena (Spain), its configuration shaped both, the very forms of transit through the mountains and the historical routes of communication that traverse Andalucia. In this paper we will explore a GIS methodology developed specifically to identify particular characteristics of the landscape that are relevant for movement such as passageways, crossing points and natural areas of transit. In our particular case study, the identification of such areas allowed us: (I) to examine the role that natural accessibility might had for late prehistoric societies of Southern Iberia in the location of their habitats and symbolic places; and (2) to determine through the examination of historical and modern paths, to what extent zones of optimal accessibility have been used through time in the establishment of communication routes. 



\section{Abbreviations}

a.s.l. above sea-level

DEM digital elevation model

DTM digital terrain model

FCVA Fuzzy Cumulative Visibility Analysis

FOV field of view

GIS Geographical Information System(s)

LCP Least Cost Path(s)

Mp Roman mile (milia passuum)

OD ordnance datum 